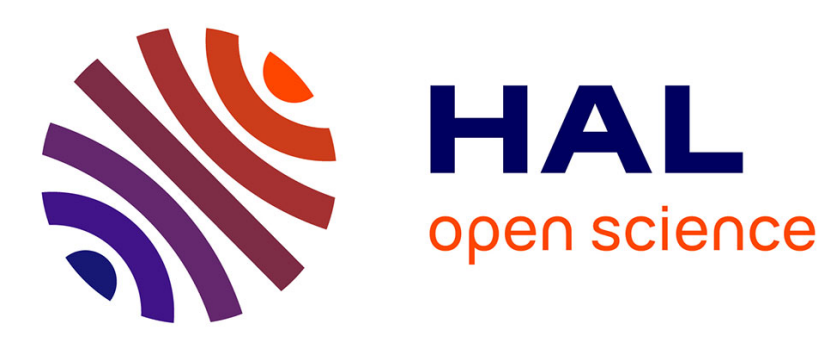

\title{
Attacking the Weak or the Strong? An Experiment on the Targets of Parochial Altruism
}

\author{
Simon Varaine, Ismaël Benslimane, Raul Magni Berton, Paolo Crosetto
}

\section{To cite this version:}

Simon Varaine, Ismaël Benslimane, Raul Magni Berton, Paolo Crosetto. Attacking the Weak or the Strong? An Experiment on the Targets of Parochial Altruism. Political Behavior, 2021, pp.1-29. 10.1007/s11109-021-09696-9 . halshs-03172630

\section{HAL Id: halshs-03172630 \\ https://shs.hal.science/halshs-03172630}

Submitted on 17 Mar 2021

HAL is a multi-disciplinary open access archive for the deposit and dissemination of scientific research documents, whether they are published or not. The documents may come from teaching and research institutions in France or abroad, or from public or private research centers.
L'archive ouverte pluridisciplinaire HAL, est destinée au dépôt et à la diffusion de documents scientifiques de niveau recherche, publiés ou non, émanant des établissements d'enseignement et de recherche français ou étrangers, des laboratoires publics ou privés. 


\title{
Attacking the Weak or the Strong?
}

\section{An Experiment on the Targets of Parochial Altruism}

\author{
Simon Varaine ${ }^{\mathrm{a}}$, Ismaël Benslimane ${ }^{\mathrm{b}}$, Raul Magni-Berton ${ }^{\mathrm{a}}$, Paolo Crosetto ${ }^{\mathrm{c}}$ \\ aUniv. Grenoble Alpes, CNRS, Science Po Grenoble*, PACTE, 38000 Grenoble, France \\ * School of Political Studies Univ. Grenoble Alpes

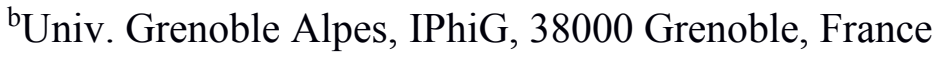 \\ 'Univ. Grenoble Alpes, CNRS, INRA, Grenoble INP*, GAEL, 38000 Grenoble, France \\ * Institute of Engineering Univ. Grenoble Alpes
}

\begin{abstract}
Studies on parochial altruism have insofar focused on the causes leading individuals to attack any outgroup on the behalf of one's group. Yet, we lack clues to understand why parochial altruists target specific groups, such as dominant groups in some contexts and minority groups in others. The present paper introduces an experiment to analyze the conditions under which individuals costly attack strong versus weak outgroups. In a first study, 300 participants played a repeated Inter-group Prisoner Dilemma involving multiple groups and inter-group differences in resources. Results show that individuals have a preference for targeting strong outgroups, but that attacks decrease when the inequality in destructive capacity between groups is high. Besides, individuals target weak outgroups when they are threatening their ingroup status. Decisions in the game correlate with participants' political ideology and Social Dominance Orientation. In a second study, we provide evidence that our results generalize to historical linkages between economic inequality and left-wing versus right-wing terrorist attacks.
\end{abstract}

\section{Key words}

Parochial altruism, Terrorism, Social comparison, Inequality, Ideology, Intergroup conflict

\section{Acknowledgments}

We would like to thank Innovacs for funding this study. We also thank Anna Cortijos Bernabeu for her work on the text. 


\section{Introduction}

A large body of research has investigated parochial altruism - i.e. the coexistence of ingroup contribution (altruism) and outgroup aggression (parochialism) (Rusch, 2014, De Dreu et al., 2014, Choi \& Bowles, 2007, Bernhard et al., 2006). The concept of parochial altruism captures a recurring pattern of inter-group relationships: that is, the costly attack of members of an outgroup on behalf of one's ingroup. "Attack" means here inflicting a loss to someone. This concept is applied to many forms of modern conflict, such as suicide-bombers sacrificing themselves to hurt their group's rivals (Ginges \& Atran, 2009, Atran \& Sheikh, 2015, Sheikh et al., 2015), and to inter-ethnic interactions (Jeon et al., 2017). While the relevance of parochial altruism is also criticized (Yamagishi and Mifune 2016), many experimental studies demonstrate that parochial altruism is a widespread tendency (Abbink et al., 2012, De Dreu et al., 2014, Bernhard et al., 2006).

Most research on parochial altruism has focused on its underlying motivations and the conditions under which it emerges. According to Choi \& Bowles (2007), the combination of altruism and parochialism may have been an evolutionary stable strategy in human evolution under conditions of competition on resources. Such motivation would have been embedded in humans across evolution through hormonal and neurologic mechanisms, shaping inter-group psychology (De Dreu et al., 2010, 2014).

Most experimental studies on parochial altruism have investigated the motivation for aggression toward any outgroup on behalf of the ingroup. Yet, in the real world, there is a great diversity of potential targets for parochial altruists. This may be illustrated by the heterogeneous targets of terrorist groups: depending on time and space, terrorism has been used against very different groups such as immigrants, minorities (Freilich et al., 2018, Ravndal, 2016), political authorities and large firms (Malkki, 2018, Hoffman, 2006). Understanding the conditions under which parochial altruists choose different targets may help to predict why certain groups receive more or less hostility in the real world and illuminate the drivers of terrorist groups' targeting choices.

In this paper we distinguish two types of parochial altruism, depending on whether attacks target outgroups with more vs. fewer resources than the ingroup. Based on the social comparison literature, we posit that these types of parochial altruism result from two forms of inter-group comparison: envy and jealousy. To test our hypotheses, we introduce a novel economic experiment allowing to identify the targets of parochial altruism (data and replication files here: https://doi.org/10.7910/DVN/K8J8GU). The hypotheses and experimental design were preregistered on Open Science Framework (details here: 
http://osf.io/neaqu $^{1}$ ). In a second study, we assess the generalizability of our results by analyzing historical linkages between economic inequality and left- versus right-wing terrorist attacks.

\section{Theoretical background}

In an environment with multiple groups, parochial altruists cannot attack all outgroups. This would be too costly and may dilute the effect of each attack. Moreover, this shooting-in-the-dark strategy may generate vindictive coalitions of outgroups against the ingroup. For a given constant incentive to attack, parochial altruists have to choose which outgroup(s) to target. The core of our argument is that the individual decision to target specific outgroups depends on the distribution of resources across the different groups (Halevy et al., 2010, Abbink et al., 2018). We identify two channels. First, insofar as inequality in resources across groups does not affect groups' safety, parochial altruism does not provide clear lines to choose to attack a specific group. In this case, literature on social comparison provides a relevant framework. Second, when inequality in resources affects groups' safety, parochial altruism predicts that the target of attacks is chosen to maximize the ingroup's safety.

\section{Social Comparison and Parochial Altruism}

Drawing from studies on social comparison, we focus on individual motivation to achieve the best relative position for their ingroup compared to outgroups. Many studies show that individuals evaluate their own payoff relatively to others rather than in absolute terms (Solnick \& Hemenway, 1998, Boyce et al., 2010, Card et al., 2012). For instance Solnick and Hemenway (1998) find that most individuals preferred a lower absolute to a higher relative income. Similarly, Boyce et al. (2010) find that relative, not absolute, income predicted life satisfaction. Similarly, neurologic evidence indicates that higher relative payments and lower relative losses compared to other individuals are related to the activation of the ventral striatum - indicating reward-related brain activity (Dvash et al., 2010, Luo et al., 2018).

Some evidence indicates that inter-group and inter-individual comparisons elicit similar mechanisms. For instance, a study based on football teams shows that fans being presented with the failures of the rival team experienced higher ventral striatum activity

\footnotetext{
${ }^{1}$ The present paper focuses on the hypotheses 2 and 3 (about social comparison) of the preregistered project. The hypothesis 1 (about the ingroup situation) is explored in a separate study.
} 
(Cikara et al., 2011). Individuals displaying high ventral striatum responses to the rivals'

failures are also more willing to harm fans of the other team (see also Hein et al., 2010). Based on this reasoning, we distinguish two forms of inter-group comparison, i.e. envy and jealousy, that respectively motivate attacks against strong and weak outgroups.

\section{Envy and attacks against strong outgroups}

Envy occurs "when a person lacks another's superior quality, achievement, or possession and either desires it or wishes that the other lacked it" (Parrott \& Smith, 1993: 906). Research demonstrates that upward comparison with people or groups with higher resources generates negative feelings that display neural signatures (Takahashi et al., 2009, Luo et al., 2018). Envy in its malign form is related to "schadenfreude": gloating when the envied other falls from grace. Various studies show that individual display positive emotions and reward-related brain activity when the envied person or group experiences losses (Takahashi et al., 2009, Dvash et al., 2010). In this line, economic experiments show that people are willing to pay to burn the money of richer individuals (Zizzo \& Oswald, 2001, Zizzo, 2003). This aligns with experimental research indicating that humans have a strong preference for inter-individual equality (Dawes et al. 2007).

At the group level, Halevy et al. (2010) analyze the effect of between-group relative deprivation on parochial altruism in a version of Inter-group Prisoner Dilemma in which individuals can use money either to benefit the ingroup or reduce the income of the outgroup without benefits for the ingroup (see Halevy et al., 2008). They find that players from relatively deprived groups are more likely to costly attack the outgroup, thus reducing the ingroup absolute welfare but increasing its relative status.

Hence, we predict that, in general, parochial altruists have a preference to target outgroups with higher resources.

\section{H1: the higher the resources of an outgroup the higher the level of attacks.}

\section{Jealousy and attacks against weak outgroups}

Jealousy is "the belief, suspicion or fear that what one desire to keep for one self is in danger of being diverted to a known or suspected rival" (Salovey \& Rodin, 1991: 396). In the case of inter-group comparison, jealousy refers to the fear that an outgroup, which was initially less well off, challenges and overtakes the ingroup's status. We posit that individuals 
are more likely to target weaker outgroups when they get close to the ingroup level of resources.

H2: the closer the outgroup is getting to the ingroup the higher the level of attacks.

\section{How Destructive Capacity Affects Envy and Jealousy}

Destructive capacity (DC) refers to the amount of harm that a group can inflict on another group. When DC is equally distributed, the groups differ only by their level of resources and their behavior. However, in real life DC is not equally distributed. The unequal level of resources introduces an inequality in harmfulness capabilities. Attacking an outgroup is then not only an act of aggression, but also an act of preemptive self-defense. Introducing DC allows for a distinction between offensive and defensive motives of participants. It produces an asymmetrical situation, in which the rich are in position to attack to maximize their personal reward, while the poor are in defense, and benefit from peaceful interactions and compete to protect against potential attacks (Böhm et al. 2016; De Dreu and Gross 2019)

DC affects the logic of envy and jealousy. Regarding envy, Abbink et al. (2018) highlight a resignation effect: if the advantage of the outgroup is far too high, the effect of an attack may be too small to alter the relative position of the ingroup. This effect explain the reduction in attacks under huge inequalities. This reduction, however, may also be explained by DC: if richer groups have higher DC, targeting a richer outgroup may be dangerous because the latter may retaliate and cause great harm to the ingroup in the future. Hence, DC modifies the incentives provided by envy in a symmetrical game.

\section{$H 1 b$ : the effect of envy $(\mathrm{HI})$ is reduced under unequal destructive capacity}

In contrast, we posit that the logic of jealousy should be especially strong when richer groups have a higher DC. Indeed, experimental studies show that fear of future attacks is a major motivation for first strikes against an outgroup (Böhm et al., 2016, De Dreu et al., 2010), more than nastiness and outgroup anger (Simunovic et al., 2013, Abbink et al., 2014). This aligns with findings from social psychology indicating that outgroup derogation increases when outgroups are threatening the ingroup (Branscombe \& Wann, 1994). Letting a group overtake one's rank is dangerous since the outgroup will be able to destroy the ingroup in the future. Hence, to secure its rank, the best option for the ingroup is to attack outgroups that are getting close to its level of resources. Hence: 
$H 2 b$ : the effect of jealousy $(H 2)$ is increased under unequal destructive capacity

\section{Overview of studies}

Our empirical analysis has two stages. The first stage (Study 1) is an experiment in which subjects can attack outgroups with varying level of resources and DC. Study 2 assesses the implications of our results for real inter-group conflicts - and more specifically terrorist attacks.

\section{Study 1: experiment}

\section{Methods}

\section{Measuring Parochial Altruism: the Inter-Group Prisoners' Dilemma}

Parochial altruism is commonly captured through the Inter-group Prisoner's Dilemma (IPD) paradigm (Bornstein, 1992, Halevy et al., 2008). In a standard version of this game, subjects are divided in 2 groups of 3 players. Each subject receives a fixed initial amount of resources in points $p_{0}$ that the subject either chooses to keep $(k)$ or to contribute to attack the outgroup $(a) \cdot p_{0}=k+a$. For each point kept, the subject gains 1 point. For each point contributed to attack the outgroup, each subject of the ingroup gains 0.5 point and each subject of the outgroup loses 0.5 point. Decisions are made simultaneously.

The payoff of a given subject is determined by the number of points $p$ gained at the end of the round. It is a function of the number of points $k$ kept, the number of points $a_{i}$ contributed in attacks by the subjects $i$ of the ingroup and the number of points $a_{j}$ contributed in attacks by the subjects $j$ of the outgroup:

$$
p=k+0.5 \times \sum_{i=1}^{3} a_{i}-0.5 \times \sum_{j=1}^{3} a_{j}
$$

This game consists of two prisoner's dilemmas embedded into each other, one at the individual level and the other at the group level. Table 1 details the actions and payoffs for a given subject. It shows that at the individual level, the Nash equilibrium is for each subject to keep. Indeed, a subject loses 0.5 points when attacking.

[Insert Table 1 around here] 
However, at the group level, the dominant group strategy is to contribute all points to

attack. Indeed, total ingroup gains are 1.5 points if the subject attacks whilst it is 1 point if she keeps. Yet, the dominant collective strategy is for all subjects to keep their points. Indeed, if all subjects attack, no subject gains any points as the gains form the ingroup's attacks are offset by the losses from the outgroup's attacks. In short, the optimal strategy is the same for selfish subjects who do not cooperate with anyone and for universalist subjects who cooperate with everyone: to keep. Only parochial altruists, who cooperate with ingroup and not with outgroup members choose to attack.

The game captures core features of parochial altruism. From a purely individual perspective, it is costly to engage in attacks on behalf of one's group. Yet, the group would be better off if all its members engaged in such attacks. However, at the aggregate social level, attacks have negative consequences.

\section{Design of the Experiment}

We propose a new version of the IPD. Subjects play a repeated IPD game over $T$ rounds (Bornstein et al., 1994, Halevy et al., 2012). Subjects stay in the same group for all rounds. We keep the payoff structure unchanged. Yet, we bring three new elements to test our hypotheses.

Firstly, we increase the number of groups. Each subject may attack different outgroups simultaneously. When deciding to contribute, subjects have to choose which outgroups to attack. The consequences for the ingroup stay the same.

Secondly, we introduce inequality across groups. This allows us to test the conditions under which subjects attack richer or poorer outgroups. Before playing the IPD game, subjects perform a word-creation task akin to a Scrabble game (for details see Authors, 2020). Differences in skill generate considerable variance. Each subject starts the IPD game with resources $p_{0}$ proportional to the results of the word-creation game. The groups for the IPD are created based on the subjects' earlier performance: the three best subjects form a group, the three second best another, and so on. This generates endogenous inter-group inequality in the IPD. Moreover, inequalities are (loosely) meritocratic, inducing feelings of entitlement.

To test $\mathrm{H} 2$, we exogenously manipulate inequality across groups. At each round, each subject receives a random endowment in points $\alpha$. This allows us to impose exogenous variation in group resources, independently from the variation that is due to the attacks across groups. The random endowment $\alpha$ is determined by three economic conditions. Every five rounds, each group is randomly assigned to one of three conditions with equal probabilities: in 
the improving condition, subjects have an endowment $\alpha$ of $6 \%$ of their resources in points $p_{0}$ by round; in the stable condition, subjects have an endowment $\alpha$ of $2 \%$ of their resources in points $p_{0}$ by round; in the declining condition, subjects have a negative endowment $\alpha$ of $-2 \%$ of their resources in points $p_{0}$ by round. Groups draw a new economic condition every five rounds. This low-frequency draws allow groups to form expectations on the future resources of the outgroups and hence has a higher chance to affect the attacking strategies of groups than higher frequency draws.

Hence, at the end of a given round, the number of points $p$ of a subject is a function of the number of points $k$ the subject kept, the number of points $a_{i}$ contributed in attacks by the subjects $i$ of the ingroup, the number of points $a_{j \rightarrow \in-\text { group }}$ invested in attacks against the ingroup by the subjects $j$ of the $n-1$ outgroups, and the subject's random endowment $\alpha$ :

$$
p=k+0.5 \times \sum_{i=1}^{3} a_{i}-0.5 \times \sum_{j=1}^{3 \times(n-1)} a_{j \rightarrow \text { ingroup }}+\alpha
$$

The number of point $p$ of a subject at the end of each round determines the resources in points $p_{0}$ with which the subject will start the next round. This also allows inequality to endogenously vary during the course of the game ${ }^{2}$.

The payoff of each subject is determined by the number of points $p$ the subject gained at the end of the last round of the game.

Finally, in our version of the game, subjects have a limit $\beta$ on the number of points $a$ they can contribute to attack outgroups at each round. $a \leq \beta$. To test H1b and H2b, we use two between-subjects treatments. In the equal destructive capacity (EDC) treatment, subjects face an absolute limit to the number of points $a$ they can contribute to attack. That is, $\beta$ is fixed. In the unequal destructive capacity (UDC) treatment, the limit $\beta$ is proportional to the subjects' resources in points $p_{0}$ at the beginning of each round. In the EDC treatment, a rich subject can attack as much as a poor subject ${ }^{3}$; in the UDC treatment, a rich subject can attack more than a poor subject. In both treatments, the rich have an advantage over the poor: the opportunity cost for attacking is lower for the rich subjects because contributing a point is relatively less costly for them. Yet, the UDC treatment enhances this advantage. If $\mathrm{H} 1 \mathrm{~b}$ is

\footnotetext{
${ }^{2}$ Our version of the IPD game entails the likelihood that subjects have negative payoffs. To address this issue, we decided that a subject who has negative points can no longer attack and no longer loses points from outgroup attacks. Yet, subjects of the outgroups continue to gain points when attacking the subject's ingroup irrespectively of the subject's number of points. When all subjects of the ingroup attain zero, we consider the ingroup "dead" and the outgroups can no longer attack it.
}

\footnotetext{
${ }^{3}$ Except the case in which the resources in points $p_{0}$ of the poor subject are below the absolute limit $\beta$.
} 
correct, subjects should diminish their attacks against richer groups in the UDC treatment. If $\mathrm{H} 2 \mathrm{~b}$ is correct, subjects should increase their attacks against close poorer groups in the UDC treatment.

Contrary to the original IPD game, our version is an iterated game and entails pathdependency in subjects' payoffs across rounds. In order to keep unchanged the dominant strategies from the original IPD capturing parochial altruism, our game has a commonly known finite number of rounds. Therefore, each round has a Nash equilibrium and the game is solved by backward induction, - i.e. deducing dominant strategies based on the last subgame. The path-dependency does not affect this result.

\section{Participants}

We recruited 300 subjects from the GAEL subject pool in Grenoble, France. 59\% of subjects were female. A majority was students $(68.33 \%)$ the rest being workers $(25.33 \%)$ or unemployed $(6.33 \%)$. The mean age was of $27(S D=9.85), 18.67 \%$ of subjects completed less than high school, 28\% had a high school diploma, 19.33\% completed a bachelor's degree, $17 \%$ completed a master's degree and $17 \%$ a Phd.

\section{Procedure and Parameterization}

The experiment took place at the GAEL experimental laboratory in Grenoble, France. The experimental software was written in Python using the oTree platform (Chen et al., 2016) ${ }^{4}$. We ran 20 sessions of 15 subjects, divided in 5 groups in the IPD game. Upon entering the lab, subjects were randomly assigned to individual computers. Instructions were read aloud and presented on overhead and individual screens. Clarification questions were answered collectively ${ }^{5}$. Subjects received a $10 €$ show-up fee, which was not at stake during the game.

Subjects first took part in the word-creation task (for details, see Authors, 2020). After completing the task, subjects were informed about their individual gains. Based on pre-tests, we estimated that subjects would start the IPD game with around 500 points on average. Subjects were then divided in groups labeled with colors - yellow, red, purple, blue and green

\footnotetext{
${ }^{4}$ Source code available here: https://gricad-gitlab.univ-grenoble-alpes.fr/ecopol/ipdradical/

${ }^{5}$ Instructions and screenshots from the software are provided in the online appendix. The oTree package is available upon request.
} 
- to be easily identified. Subjects played the IPD game for 15 rounds, putting at stake their individual gains from the first task.

We implemented a $2 \times 3$ design. Half of the subjects played in the $E D C$ treatment, with the limit $\beta$ fixed at 50 points; the other half in the $U D C$ treatments, the limit $\beta$ fixed at $10 \%$ of their points at the beginning of each round. Besides, every 5 rounds, each group was randomly assigned to one of the three economic conditions determining the subject random endowment. Table 2 summarizes the experimental conditions and the actual share of subjects that were assigned to a given condition.

[Insert Table 2 around here]

Figure 1 shows a screenshot of the interface. During each round, subjects had information on: their economic condition, their individual number of points, the total number of points of each group - identified by their color - and a line plot of their variations during the past rounds. During the round, the subjects decided how much of their points to keep or to contribute to attack each outgroup, being blinded to the other subjects' decisions. After each round, subjects had information on the variation of their individual resources, the number of points gained by the ingroup due to the attacks made by them and the other members of the ingroup, the number of points lost by the ingroup due to the attacks of the different outgroups - identified by their color - and the number of points gained/lost by the ingroup due to the economic condition.

\section{[Insert Figure 1 around here]}

At the end of the game, subjects filled out a short socio-demographic questionnaire. We also asked subjects whether they found themselves and the other subjects cooperative during the game. This allows us to check whether attacking outgroups is perceived as cooperative behavior, in line with results from the literature on the IPD (Halevy et al., 2008, Weisel \& Böhm, 2015, Halevy et al., 2012). We included a political and a psychometric measure to test the relationship between attacks against richer and poorer outgroups and the subjects' political attitudes. Subjects indicated their political self-placement on a scale from 1 (left) to 10 (right) and filled out the French short version of the Social Dominance Orientation scale in 8 items (Bizumic et al., 2008) - which captures individual's sense that some groups are inferiors and that some groups should dominate in society (Sidanius \& Pratto, 2001). 


\section{Empirical strategy}

To test our hypotheses, our main analyses are based on subject-outgroup dyads by round. As we analyze 300 subjects who face 4 outgroups for 15 rounds, the total number of subjectoutgroup dyads is $\mathrm{N}=18,000$. Note that we exclude observations of subjects that had no more resources to contribute in a round and of all subjects in rounds in which one group or more was dead, in order to alleviate potential biases in the comparisons ${ }^{6}$. The resulting data has a panel structure: measures of subjects' attack behaviors against the outgroups are repeated across the 15 rounds. To take into account this panel structure of data, we relied on multilevel regression models with random effects computed at the subject level when testing our hypotheses ${ }^{7}$.

\section{Results}

\section{Gameplay and Learning in the Game}

Consistent with the IPD literature, subjects engage in a considerable level of attacks. On average, subjects contribute over the whole course of the game 390 points in attacks ( $S D=181$ ), which represent around $75 \%$ of their resources in points at the beginning of the game $(M=522, S D=156)$. As a result, subjects lose a significant amount of money because of their mutual attacks. The mean payment at the end of a session was $6.35 €(S D=$ 4.22). If no subject ever attacked, the mean payment would have been of $17.55 €$. Subjects on average lost $65 \%$ of their payoff because of their mutual attacks. There is a significant difference in mean payoffs between the treatments: $5.28 €(S D=3.67)$ in the EDC treatment and $7.42 €(S D=4.47)$ in the UDC treatment, $t(298)=-4.537, p<.001$.

Subjects could attack in the first rounds but then learn in time to attack less. Figure 2 plots the distribution of our main dependent variable: the level of individual attacks against an outgroup, i.e. the number of points contributed by a given subject to attack a given outgroup, by round ${ }^{8}$. A first general observation is that the level of individual attacks is overdispersed, with around half subjects (44.64\%) contributing no points, and a few subjects contributing

\footnotetext{
${ }^{6}$ This reduces the sample to $\mathrm{N}=17,728$. Including all observations in the analyses does not alter our conclusions. The authors can send results upon request.

Note that the sample is further reduced in the regression analyses, due to the inclusion of some variables (e.g. variable measuring behaviors during a previous round). We specify in notes under the regression tables the rationale behind sample reductions.

${ }^{7} \mathrm{We}$ also present in the online appendix alternative models based on ingroup-outgroup dyads with ingroup random effects and models based on subject-outgroup dyads with subject fixed effects.

${ }^{8}$ Detailed summary statistics are provided in the online appendix.
} 
many points: the upper quartile of the level of individual attacks against an outgroup is 10 points and the upper decile 19 points. To be clear, this distribution does not mean that the overall level of attack is low: it means that subjects do not equally attack all outgroups during a given round but rather concentrate their attacks against some outgroups while not attacking others.

Regarding the evolution of attacks, we see little convergence toward the dominant individual strategy. In both treatments the median absolute level of individual attacks decreases through the game. However, this mainly reflects the fact that subjects have fewer resources, as the points contributed in attacks as a percentage of available resources increase through the game (see appendix).

\section{[Insert Figure 2 around here]}

Figure 3 plots the mean resources of the five groups, i.e. the sum of the resources in points of the subjects of each group, across rounds. We see that in both the UDC and EDC treatments, group resources decrease for all groups because of mutual attacks. We see different patterns by treatment. In EDC rich groups lose relatively more resources than poor groups, leading to close levels of resources for all groups at the end of the last round. In contrast, in UDC the slopes are quite similar from the richer to the poorer groups, leading to a higher level of inter-group inequality in the last rounds.

[Insert Figure 3 around here]

\section{Confirmatory analyses}

Table 3 describes the mean level of individual attacks against an outgroup depending on the experimental treatment and the outgroup economic condition. Table 3 decomposes the level of individual attacks depending on whether the outgroup is richer - i.e. the outgroup has more resources than the ingroup - or poorer - i.e. the outgroup has fewer resources than the ingroup. Note that the high standard deviations reflect the above mentioned overdispersion of the level of individual attacks. Boxplots presented in Figure 4 give a better view of the distribution of the level of individual attacks against an outgroup across conditions.

[Insert Table 3 around here]

[Insert Figure 4 around here] 


\section{Hypothesis 1: envy and attacks against strong outgroups}

Do subjects contribute more points to attack strong outgroups (H1)? Table 3 and Figure 4 suggest that the level of attack is generally higher against richer outgroups (in red) compared to poorer outgroups (in blue). Table 4 presents estimates from multilevel negative binomial regressions ${ }^{9}$ of the level of individual attacks against an outgroup at a given round, with random effect computed at the subject-level to account for the panel structure of the data. Model I confirms that richer outgroup are significantly more attacked than poorer outgroups, in line with H1. This effect is significant when controlling for previous attacks by the outgroup against the ingroup and the ingroup rank, which directly determines the number of richer/poorer groups "available" to attack.

\section{[Insert Table 4 around here]}

To further investigate this relationship, Figure 5 plots the level of individual attacks against an outgroup depending on the outgroup resources, i.e. the sum of the resources in points of the subjects of the outgroup. In line with H1, results suggest that the higher the outgroup resources, the higher the level of attacks. To assess the robustness of this results, we ran a range of regression models of the level of attacks - detailed in the online appendix. We first tested negative binomial regression models based on ingroup-outgroup dyads with ingroup random effects, and subject-outgroup dyads with subject fixed effects. We then tested zero-inflated negative binomial models that separately predict the probability of no attack, and the number of points contributed in case of attack. The models control for the subject (or ingroup) resources and previous attacks from the outgroup. All models confirm that the higher the resources of an outgroup the higher the level of attacks against it.

\section{[Insert Figure 5 around here]}

Does the UDC treatment moderate the effect of the outgroup resources (H1b)? Table 3 and Figure 4 suggest that in both the EDC and UDC treatment, subjects attack richer outgroups more than poorer outgroups, but the difference between these levels of attack is lower in the UDC treatment. Model II of Table 4 confirm that there is a significant negative

\footnotetext{
${ }^{9}$ The negative binomial regression is a generalization of the poisson regression for count variables with overdispersion (the variance exceeds the mean). Such model is appropriate for our dependent variable, which is an observed count (of the number of points contributed in attacks) with overdispersion (M=6.54, Var=100.61).
} 
interaction between the outgroup being richer and the UDC treatment. This gives initial support to $\mathrm{H} 1 \mathrm{~b}$, that the higher destructive capacity of richer groups reduces the attacks targeting them.

We tested for the interaction between the UDC treatment and the outgroup level of resources in various regression models presented in the online appendix. Contrary to our expectation, the interaction is insignificant in most models. To further investigate the potential interaction effect, we tested whether the shape of the effect of the outgroup resources differ across treatments, by including a quadratic term of the outgroup resources. Results indicate significant differences in the shape of the effect of the outgroup resources across treatments, as illustrated by the quadratic fit of Figure 5. Overall, regression results show that the effect of the outgroup resources is exponential in the EDC treatments - i.e. the subjects concentrate their contributions in attacks against the very richest outgroups - while the effect of the outgroup resources is linear in the UDC treatments. This gives support to the view that subjects refrain from attacking the richest outgroups when they have a higher destructive capacity, in line with H1b.

\section{$\underline{\text { Jealousy and attacks against weak outgroups }}$}

Do subjects attack poorer outgroups (H2) when they get close to the ingroup level of resources? If $\mathrm{H} 2$ is true, poorer outgroups should be attacked more when they are in an improving economic condition - i.e. they are getting closer to the ingroup - while this should not be the case for richer outgroup. Table 3 and Figure 4 suggest that the more favorable the economic condition of the poorer outgroup the higher the level of individual attacks it receives. Looking specifically at the effect of the improving condition, Model III of Table 4 reveals that an outgroup in improving condition is significantly more attacked compared to an outgroup in declining or stable condition. If $\mathrm{H} 2$ is true, this effect should not be found for richer outgroups. To test this prediction, Model III includes an interaction term between the improving outgroup condition and the outgroup being richer. As expected, there is a significant negative interaction, which indicates that the positive effect of the improving outgroup condition on the level of attacks is lower when the outgroup is richer.

However, a look at the size of the interaction term suggest that the positive effect of the outgroup condition is not entirely suppressed for richer outgroup. This result is confirmed in various regression models presented in the online appendix - analyzing ingroup-outgroup dyads with ingroup fixed effects, subject-outgroup dyads with subject fixed effects or using zero-inflated models. Overall, results indicate that subjects attack more poorer outgroups in 
improving condition but that this effect is also found (albeit to a lesser extent) for richer outgroups. This gives limited support to $\mathrm{H} 2$.

Does the UDC treatment moderate the effect of the outgroup economic condition (H2b)? Table 3 and Figure 4 suggest that poorer outgroups in improving condition are attacked more in the UDC treatment, as predicted by H2b. Model IV of Table 4 includes a three-way interaction between the treatment, the outgroup improving condition (compared to the declining and stable economic conditions) and the outgroup being richer. To give a better view of the interaction effect, Figure 6 plots the mean level of individual attacks by outgroup economic condition based on model IV. It confirms that the UDC treatment moderates the effect of the outgroup improving condition on the level of attacks against richer and poorer outgroups: poorer outgroups are significantly more attacked when they are in improving condition in the UDC treatment, while such positive interaction effect is not found for richer outgroups.

[Insert Figure 6 around here]

This result is confirmed in various regression models presented in the online appendix. Overall, this result suggests that when all groups have the same destructive capacity, subjects are envious: they tend to attack more richer outgroups that have prospects to become even richer. In contrast, under unequal destructive capacity, the attacks are also consistent with jealousy. The poorer outgroups with prospects to become richer are attacked significantly more in the UDC treatment.

\section{Exploratory analyses}

Are behaviors in the game correlated with subjects' characteristics? Table 5 presents results from negative binomial regressions of the level of individual attacks against an outgroup with subject random effects. The models include at a first level independent variables related to the game, and at the second level subjects' characteristics - including attitudinal and socio-demographic variables ${ }^{10}$.

[Insert Table 5 around here]

\footnotetext{
${ }^{10}$ Descriptive statistics and bivariate analyses of the level of individual attacks by subjects' characteristics are presented in the online appendix.
} 
Results based on the post-experimental survey indicate that behaviors in the game correlate with subjects' attitudes. Firstly, in line with previous studies on parochial altruism, attacks are perceived as altruistic behavior. Model I shows that subjects who perceive themselves as cooperative during the game actually contribute significantly more points to attacks. Interestingly, model II shows that there is a significant negative interaction between perceived self cooperation and the outgroup being richer on the level of attacks against it. We comment this finding in the concluding part of the paper.

Secondly, we test for the relationship between the targets of parochial altruism and the political attitudes of subjects. Model III shows that there is a significant interaction between subjects' self position on the left-right scale and the outgroup being richer, which indicates that the more subjects are at the right the less they attack richer outgroups. Model IV tests for a similar interaction effect with Social Dominance Orientation (Cronbach's $\alpha=0.73$ ). Results show that Social Dominance Orientation increases the overall level of attacks, but that there is a significant negative interaction with the outgroup being richer. A look at the sizes of the main effect and the interaction effect reveals that Social Dominance actually has no effect on the level of attacks against a richer outgroup, while it has a significant positive effect on the level of attacks against a poorer outgroup. The interaction term is still significant in the final model VI including all interaction terms with the outgroup being richer. In contrast, the interaction term with the left-right self position is no longer significant in model VI. Further analyze that this loss of significance is due to the inclusion of the interaction term of Social Dominance Orientation. This indicates that Social Dominance Orientation, rather than leftright orientation, primarily determines the choice of targeting richer versus poorer outgroups. Finally, the models in Table 1 include socio-demographic variables. None of these variables are statistically related to the level of attacks.

Results from the game-level variables confirm the previous analyses. An outgroup is attacked more when it has large resources. An outgroup is also attacked more when its resources are growing because of its economic condition. Moreover, the results show that subjects tend to attack in retaliation of previous attacks by the outgroup and to attack more when members of their ingroup contributed in attacks during the previous round.

Finally, we included an indicator of inequality across groups in the models. Inequality is measured, using a fractionalization index, as the sum of the squared share of resources respectively owned by the five groups ${ }^{11}$. Results from model I show that, overall, attacks concentration of the resources in the richest group). Empirically, the variable goes from $20.0 \%$ to $34.2 \%$. 
decrease when inequality is high. Model V shows that this effect of inequality is actually different when we distinguish between attacks against richer and poorer outgroups. The interaction term indicates that inequality specifically reduces attacks against richer outgroups while it has no effect on attacks against poorer outgroups.

\section{Discussion}

Our experiment partly confirms previous results on parochial altruism and partly introduces new evidence. We confirm that participants choose to spend substantial amounts of money to attack outgroups for the benefit of their ingroup, thus reducing collective welfare (Bornstein, 2003). We also corroborate that attacks mainly emerge from "ingroup love" rather than "outgroup hate" (Halevy et al., 2008, Halevy et al., 2012; Abbink et al. 2018). New evidence is provided about the targets of parochial altruism: on average, subjects choose to attack richer outgroups more. However, when the destructive capacity of groups increases with their resources, richer outgroups are less attacked and poorer outgroups more, especially when they have good prospects to become rich.

Exploratory analyses show that the targets of parochial altruism correlate with subjects' political attitudes: subjects on the left contribute significantly more money to attack richer outgroups, while subject high in Social Dominance Orientation contribute significantly more money to attack poorer outgroups. This suggests that our experimental setting is an effective measure of the ideological orientation of individuals in inter-group interactions, and that the results may be extrapolated to inter-group conflicts.

\section{Study 2: terrorist attacks}

In this study, we assess the implications of our results regarding the effect of inequality on terrorist attacks. Terrorism refers to use of violence by sub-national actors to achieve political aims (Krueger, 2009). Terrorism can be considered an archetypal form of parochial altruism. As other forms of inter-group conflict, terrorism is characterized by individuals inflicting costs to outgroups for the (expected) benefit of the ingroup. Crucially, in contrast with other forms of inter-group conflict, evidence indicates that most terrorists behave on altruistic motives: most terrorists behave by their own volition and do not benefit personally from their involvement (Ginges \& Atran, 2009, Atran \& Sheikh, 2015, Sheikh et al., 2015). This distinguishes terrorism from both constrained involvement in violence, such as conscript armies in state-based wars (Poutvaara \& Wagener, 2011) or forced involvement in civil wars (e.g. see Zack-Williams, 2001), and from involvement in violence due to 
selective incentives, which prevails for professional armies and is a main factor in civil wars (Collier \& Hoeffler, 2004).

If we start from the realistic assumption that the destructive capacity of individuals is associated with their wealth in the real world ${ }^{12}$, this capacity is equally distributed across individuals in equal societies, while it is unequally distributed in unequal societies. Therefore, our theory implies that terrorism targeting strong outgroups should decrease under high inequality, while terrorism targeting weak outgroups should increase under high inequality.

The targeting of strong versus weak outgroups partly matches with the divide between left-wing and right-wing terrorism. According to the classification of Kis-Katos et al. (2014), left-wing terrorist groups have a socialist, communist, or anarchist ideology. Hostility toward strong outgroups is a key feature of these ideologies, whose defining goal is to reduce social inequalities (Kis-Katos et al., 2014). In particular, the rejection of economic-based dominance is central in left-wing ideologies: "a common feature of left-wing terrorism is its opposition to capitalism and support for a revolution that would lead to a profound alteration of power relations and a society governed according to communist principles" (Malkki, 2018, p.88). This typically translates into the targeting of economically strong outgroups: their attacks are "typically directed against governmental or commercial institutions, or specific individuals who they believe represent capitalist exploitation and repression" (Hoffman, 2006, p.231).

Conversely, right-wing terrorism is inspired by national-socialist or fascist ideologies, who actively promote racial or national supremacy, hatred, or xenophobic ideas (Kis-Katos et al. 2014). The common feature of these ideologies consists in targeting outgroups which are not defined along economic divides, even though homeless people are common targets of right-wing terrorists (Freilich et al., 2018, Ravndal, 2016). Right-wing terrorist groups do not target the rich. Among a multitude of non-rich people, they target those who can be identified as outgroups. For example, a recurring pattern is the targeting of immigrant and minority groups (Freilich et al., 2018, Ravndal, 2016). This means that economic inequality should have less impact on right-wing terrorism. Yet, one can argue that immigrants and minority groups targeted by right-wing terrorism are often disadvantaged economically, especially in developed countries.

Summing up, our theory implies that inequality decreases left-wing terrorism, while it increases right-wing terrorism. This effect is paradoxical since left-wing terrorism precisely

\footnotetext{
${ }^{12}$ In unequal societies, economically powerful groups have a higher political influence on policies (Gilens, 2012).
} 
fights against inequality. However, following $\mathrm{H} 1 \mathrm{~b}$ and our experimental results, we predict that inequality decreases terrorism targeting the rich because it increases the destructive capacity of rich groups. Rich groups in unequal societies have a higher capacity to deter and retaliate against left-wing terrorists (Acemoglu \& Robinson, 2005), leading to a reduction of left-wing terrorism. The aim of this second study is to test this relationship based on historical data on terrorist attacks.

\section{Method}

\section{Left-wing and right-wing terrorist attacks}

To measure terrorist attacks, we relied on the Global Terrorism Database (National Consortium for the Study of Terrorism and Responses to Terrorism, 2017). It is the most comprehensive database covering terrorist attacks worldwide from 1970 to 2018 . We identify left-wing and right-wing terrorist attacks based on the coding of terrorist groups constructed by Kis-Katos et al. (2014). We generated two dependent variables counting the number of left-wing and right-wing terrorist attacks by country-year.

\section{Independent variables}

We measured inequality as the share of the pre-tax national income owned by the $1 \%$ richest, based on the World Inequality Database (2017). In contrast to the other measures of inequality (such as the Gini coefficient) capturing the general distribution of wealth, this variable directly measures the relative wealth of the richest economic group in a given society. As country data on inequality include gaps, we interpolated values for years with missing values ${ }^{13}$.

We control for a range of factors that have proven to affect terrorist attacks in general, or left-wing versus right-wing terrorism in particular. These include: population size, share of youth, ethno-political exclusion, level of democracy, regime durability, government size, civil war, per-capita GDP and long-term economic growth. Detailed rationale, sources and coding for these variables are provided in the online appendix.

\section{Sample and empirical strategy}

We merged all variables by country and year. We limit our analyses to countries with valid observations for the independent variables that experienced at least one left-wing or

\footnotetext{
${ }^{13}$ The results are robust to dropping interpolation, Robustness checks are available upon request.
} 
right-wing terrorist attack in the Global Terrorism Database. The final sample gathers 652 observations from 24 countries $^{14}$ in a period ranging from 1972 to 2016.

We used negative binomial regression models, which are standard in analyses of counts of terrorist attacks. For each dependent variable (i.e. left-wing and right-wing terrorist attacks), we report a first model including all independent variables, a second including country fixed effects, and a third including year fixed effects. This allows assessing the robustness of our findings. All independent variables are one-year lagged.

\section{Results}

Left-wing terrorist attacks are more frequent that right-wing terrorist attacks. The mean number of left-wing terrorist attacks by country and year is $11.6(S D=42)$, while it is $1.34(S D=5.62)$ for right-wing terrorist attacks. This difference is significant (MannWhitney $\mathrm{U}, Z=9.212, p<.001)$. This result is consistent with our experimental finding that the level of attacks against strong outgroups is higher than the level of attacks against weak outgroups.

\section{[Insert Table 6 around here]}

What is the effect of inequality on left-wing and right-wing terrorist attacks? Table 6 reports estimates from negative binomial regressions of left-wing (models I to III) and right wing (models IV to VI) terrorist attacks. As expected, results from model I show that inequality has a significant negative effect on the number of left-wing attacks. The coefficient is still negative and significant in models II and III including country and year fixed effects.

Contrary to our theoretical expectation but in line with our experimental findings, inequality has no robust effect on the number of right-wing attacks. The coefficient is insignificant in models IV and V. The effect of inequality becomes significant in model VI including country and year fixed effects: the higher the level of inequality the higher the number of right-wing attacks.

Summing up, in line with our experimental results, inequality has a different effect on left- and right-wing terrorist attacks: left-wing attacks are more frequent when inequality is low, while there is no robust relationship in the case of right-wing terrorism.

\footnotetext{
${ }^{14}$ The final sample includes Australia, Brazil, Canada, Colombia, Finland, France, Germany, India, Indonesia, Italy, Japan, Lebanon, the Netherlands, Norway, Poland, Portugal, Russia, South Africa, Spain, Sweden, Turkey, United Kingdom, United States and Uruguay.
} 


\section{General discussion}

Our results shed light on the linkages between inequality and the orientation of political violence. A historical look reveals close relationships between ideological waves of political violence and the variation in inequality. For instance, high levels of inequality in Europe in the 1930s coincided with a right-wing orientation of political violence, incarnated by the Nazi Party in Germany, the Young Patriots in France and the British Union of Fascists in the UK. In contrast, violent political movements in the 1970s, under unprecedented low levels of inequality, were mainly left-wing oriented, as illustrated by the Red Brigades in Italy, the Red Army Faction in Germany or Direct Action in France. In the current context of increasing inequalities, right-wing violence seems again to gain prevalence over left-wing violence. Recent empirical studies on French radical movements (Varaine, 2018) and US terrorists (Varaine, 2019) statistically confirm this trend: the higher the increase in inequality the more right-wing the orientation of political violence.

Our experiment offers clues to understand this relationship. Our results suggest that inequalities may lead to a right-wing orientation of political violence. Not only through increasing right-wing violence, but through decreasing the share of left-wing violence targeting strong groups. In the experiment we show that this is due to the increasing retaliation capacity of economically dominant groups rather than to a resignation mechanism (Abbink et al., 2018): when group resources are not associated with destructive capacity, the effect is not observed. This dampening effect of inequality on left-wing parochial altruism is paradoxical since left-wing ideologies precisely strive against inequality. Yet, results from Study 2 based on historical data confirm that the level of economic inequality in a country significantly reduces the incidence of left-wing terrorist attacks, while it does not affect rightwing terrorist attacks.

Besides, our experiment helps understand the relationship between the economic mobility of social groups and the orientation of political violence. Various comparative studies find that increases in the demographic and economic status of minority groups are related to increases in right-wing violence targeting them (Green et al., 1998, Boutcher et al., 2017). Results from our experiment suggest that a logic of jealousy may be at play here, leading members of strong groups to target weaker groups with high prospects of prosperity, as a preemptive self-defense attack.

Finally, results from our post-experimental survey show two main implications. Firstly, we found that the targets of parochial altruism correlate with subjects' political 
attitudes. This is a significant finding since evidence on the relationship between political variables and actual behaviors in economic games has so far mostly been inconclusive (see Grünage and Reuter, 2020). Recently, Grünage and Reuter (2020) found that left-wing political orientation is related to more cooperative behavior in public good and trust games. Our results suggest that political orientation may have different effects on cooperative behaviors in specific cases in which cooperation implies damages for outgroups. We found that left-wing political orientation may increase ingroup cooperation that harms richer outgroups, while Social Dominance Orientation increases ingroup cooperation that harms poorer outgroups. This confirms the usefulness of distinguishing between the two forms of parochial altruism that may have distinct psychological and social antecedents.

Secondly, we found that subjects' perceived level of cooperation is related to attacks against poorer groups, while it has a limited effect on attacks against richer groups. This result is close from the findings of Halevy et al. (2010) that, although attacks are generally based on altruistic motives, attacks against relatively advantaged groups may be inspired by purely hateful motives. This is also congruent with recent evidence suggesting that the widespread individual tendency to punish non-cooperative players result from a basic human inequality aversion rather than from a desire of reciprocity (Dawes et al., 2007, Raihani \& McAuliffe, 2012). An implication of this finding is that individual identification with an ingroup may not be a pre-requisite for all types of political violence, contrary to predictions of the identity fusion model of conflict (Whitehouse et al., 2014, Atran et al., 2014). Although individual identification with an ingroup may be crucial in motivating right-wing violence, left-wing violence might in some cases emerge solely from personal inequality aversion.

\section{References}

Abbink, K., \& de Haan, T. (2014). Trust on the brink of Armageddon: The first-strike game. European Economic Review, 67, 190-196.

Abbink, K., Brandts, J., Herrmann, B., \& Orzen, H. (2012). Parochial altruism in inter-group conflicts. Economics Letters, 117(1), 45-48.

Abbink, K., Masclet, D., \& Mirza, D. (2018). Inequality and inter-group conflicts: experimental evidence. Social Choice and Welfare, 50(3), 387-423.

Acemoglu, D., \& Robinson, J. A. (2005). Economic origins of dictatorship and democracy. Cambridge University Press.

Atran, S., \& Sheikh, H. (2015). Dangerous terrorists as devoted actors. In Evolutionary perspectives on social psychology (pp. 401-416). Springer, Cham. 
Atran, S., Sheikh, H., \& Gomez, A. (2014). Devoted actors sacrifice for close comrades and sacred cause. Proceedings of the National Academy of Sciences, 111(50), 17702-17703.

Authors (2020), Intellectual property reform in the laboratory, Working Papers, Grenoble Applied Economics Laboratory (GAEL).

Bernhard, H., Fischbacher, U., \& Fehr, E. (2006). Parochial altruism in humans. Nature, 442(7105), 912.

Bizumic, B., Duckitt, J., Popadic, D., Dru, V., \& Krauss, S. (2009). A cross- cultural investigation into a reconceptualization of ethnocentrism. European Journal of Social Psychology, 39(6), 871-899.

Böhm, R., Rusch, H., \& Gürerk, Ö. (2016). What makes people go to war? Defensive intentions motivate retaliatory and preemptive intergroup aggression. Evolution and Human Behavior, 37(1), 29-34.

Bornstein, G. (1992). The free-rider problem in intergroup conflicts over step-level and continuous public goods. Journal of Personality and Social Psychology, 62(4), 597.

Bornstein, G. (2003). Intergroup conflict: Individual, group, and collective interests. Personality and social psychology review, 7(2), 129-145.

Bornstein, G., Erev, I., \& Goren, H. (1994). The effect of repeated play in the IPG and IPD team games. Journal of Conflict resolution, 38(4), 690-707.

Boutcher, S. A., Jenkins, J. C., \& Van Dyke, N. (2017). Strain, ethnic competition, and power devaluation: white supremacist protest in the US, 1948-1997. Social Movement Studies, 16(6), 686-703.

Boyce, C. J., Brown, G. D., \& Moore, S. C. (2010). Money and happiness: Rank of income, not income, affects life satisfaction. Psychological Science, 21(4), 471-475.

Branscombe, N. R., \& Wann, D. L. (1994). Collective self- esteem consequences of outgroup derogation when a valued social identity is on trial. European Journal of Social Psychology, 24(6), 641-657.

Brüggemann, J., Crosetto, P., Meub, L., \& Bizer, K. (2016). Intellectual property rights hinder sequential innovation. Experimental evidence. Research Policy, 45(10), 2054-2068.

Card, D., Mas, A., Moretti, E., \& Saez, E. (2012). Inequality at work: The effect of peer salaries on job satisfaction. American Economic Review, 102(6), 2981-3003.

Choi, J. K., \& Bowles, S. (2007). The coevolution of parochial altruism and war. Science, 318(5850), 636-640.

Cikara, M., Botvinick, M. M., \& Fiske, S. T. (2011). Us versus them: Social identity shapes neural responses to intergroup competition and harm. Psychological science, 22(3), 306-313. 
Collier, P., \& Hoeffler, A. (2004). Greed and grievance in civil war. Oxford economic papers, 56(4), 563-595.

Dawes, C. T., Fowler, J. H., Johnson, T., McElreath, R., \& Smirnov, O. (2007). Egalitarian motives in humans. Nature, 446(7137), 794.

De Dreu, C. K., \& Gross, J. (2019). Revisiting the form and function of conflict: Neurobiological, psychological, and cultural mechanisms for attack and defense within and between groups. Behavioral and brain sciences, 42 .

De Dreu, C. K., Balliet, D., \& Halevy, N. (2014). Parochial cooperation in humans: forms and functions of self-sacrifice in intergroup conflict. In Advances in motivation science (Vol. 1, pp. 1-47). Elsevier.

De Dreu, C. K., Greer, L. L., Handgraaf, M. J., Shalvi, S., Van Kleef, G. A., Baas, M., ... \& Feith, S. W. (2010). The neuropeptide oxytocin regulates parochial altruism in intergroup conflict among humans. Science, 328(5984), 1408-1411.

Dvash, J., Gilam, G., Ben- Ze'ev, A., Hendler, T., \& Shamay- Tsoory, S. G. (2010). The envious brain: the neural basis of social comparison. Human brain mapping, 31(11), 17411750 .

Freilich, J. D., Chermak, S. M., Gruenewald, J., Parkin, W. S., \& Klein, B. R. (2018). Patterns of fatal extreme-right crime in the United States. Perspectives on Terrorism, 12(6), 38-51.

Gilens, M. (2012). Affluence and influence: Economic inequality and political power in America. Princeton University Press.

Ginges, J., \& Atran, S. (2009). What motivates participation in violent political action. Annals of the New York Academy of Sciences, 1167(1), 115-123.

Green, D. P., Strolovitch, D. Z., \& Wong, J. S. (1998). Defended neighborhoods, integration, and racially motivated crime. American Journal of Sociology, 104(2), 372-403.

Grünhage, T., \& Reuter, M. (2020). Political Orientation is Associated with Behavior in Public-Goods-and Trust-Games. Political Behavior, 1-26.

Halevy, N., Bornstein, G., \& Sagiv, L. (2008). "Ingroup love" and "outgroup hate" as motives for individual participation in intergroup conflict: A new game paradigm. Psychological science, 19(4), 405-411.

Halevy, N., Chou, E. Y., Cohen, T. R., \& Bornstein, G. (2010). Relative deprivation and intergroup competition. Group Processes \& Intergroup Relations, 13(6), 685-700.

Halevy, N., Weisel, O., \& Bornstein, G. (2012). "In-group love" and "out-group hate" in repeated interaction between groups. Journal of Behavioral Decision Making, 25(2), 188-195. 
Hein, G., Silani, G., Preuschoff, K., Batson, C. D., \& Singer, T. (2010). Neural responses to ingroup and outgroup members' suffering predict individual differences in costly helping. Neuron, 68(1), 149-160.

Heisig, J. P., \& Schaeffer, M. (2019). Why You Should Always Include a Random Slope for the Lower-Level Variable Involved in a Cross-Level Interaction. European Sociological Review, 35(2), 258-279.

Hoffman, B. (2006). Inside terrorism. Columbia university press.

Jeon, S., Johnson, T., \& Robinson, A. L. (2017). Nationalism and Social Sanctioning Across Ethnic Lines: Experimental Evidence from the Kenya-Tanzania Border. Journal of Experimental Political Science, 4(1), 1-20.

Kis-Katos, K., Liebert, H., \& Schulze, G. G. (2014). On the heterogeneity of terror. European Economic Review, 68, 116-136.

Luo, Y., Eickhoff, S. B., Hétu, S., \& Feng, C. (2018). Social comparison in the brain: A coordinate- based meta- analysis of functional brain imaging studies on the downward and upward comparisons. Human brain mapping, 39(1), 440-458.

Malkki, L. (2018). Left-wing terrorism. In Routledge Handbook of Terrorism and Counterterrorism (p. 87-97). Routledge.

National Consortium for the Study of Terrorism and Responses to Terrorism (START). (2017). Global Terrorism Database. http://www.start.umd.edu/gtd/

Parrott, W. G., \& Smith, R. H. (1993). Distinguishing the experiences of envy and jealousy. Journal of personality and social psychology, 64(6), 906.

Poutvaara, P., \& Wagener, A. (2011). The political economy of conscription. The handbook on the political economy of war, 154-172.

Raihani, N. J., \& McAuliffe, K. (2012). Human punishment is motivated by inequity aversion, not a desire for reciprocity. Biology letters, 8(5), 802-804.

Ravndal, J. A. (2015). Thugs or Terrorists? A Typology of Right-Wing Terrorism and Violence in Western Europe. Journal for Deradicalization, 0(3), 1-38.

Ravndal, J. A.. (2016). Right-wing terrorism and violence in Western Europe : Introducing the RTV dataset. Perspectives on Terrorism, 10(3), 2-15.

Rusch, H. (2014). The evolutionary interplay of intergroup conflict and altruism in humans: a review of parochial altruism theory and prospects for its extension. Proceedings of the Royal Society of London B: Biological Sciences, 281(1794), 20141539.

Salovey, P., \& Rodin, J. (1991). Provoking jealousy and envy: Domain relevance and selfesteem threat. Journal of Social and Clinical Psychology, 10(4), 395-413. 
Sheikh, H., Atran, S., Ginges, J., Wilson, L., Obeid, N., \& Davis, R. (2014). The devoted actor as parochial altruist: Sectarian morality, identity fusion, and support for costly sacrifices. Cliodynamics, 5(1).

Sidanius, J., \& Pratto, F. (2001). Social dominance: An intergroup theory of social hierarchy and oppression. Cambridge University Press.

Simunovic, D., Mifune, N., \& Yamagishi, T. (2013). Preemptive strike: An experimental study of fear-based aggression. Journal of Experimental Social Psychology, 49(6), 11201123.

Snijders and Bosker (2012). Snijders, T. A. B., \& Bosker, R. J. (2011). Multilevel Analysis : An Introduction to Basic and Advanced Multilevel Modeling. SAGE.

Solnick, S. J., \& Hemenway, D. (1998). Is more always better?: A survey on positional concerns. Journal of Economic Behavior \& Organization, 37(3), 373-383.

Takahashi, H., Kato, M., Matsuura, M., Mobbs, D., Suhara, T., \& Okubo, Y. (2009). When your gain is my pain and your pain is my gain: neural correlates of envy and schadenfreude. Science, 323(5916), 937-939.

Varaine, S. (2018). Bad times are not good times for revolutions: Collective deprivation and the mobilization level of F rench radical movements (1882-1980). Journal of Community \& Applied Social Psychology, 28(4), 258-271.

Varaine, S. (2019). Revisiting the Economics and Terrorism Nexus: Collective Deprivation, Ideology and Domestic Radicalization in the US (1948-2016). Journal of Quantitative Criminology, 1-33.

Weisel, O., \& Böhm, R. (2015). "Ingroup love" and "outgroup hate" in intergroup conflict between natural groups. Journal of experimental social psychology, 60, 110-120.

Whitehouse, H., McQuinn, B., Buhrmester, M., \& Swann, W. B. (2014). Brothers in Arms: Libyan revolutionaries bond like family. Proceedings of the National Academy of Sciences, 111(50), 17783-17785.

World Inequality Database. (2017). Pre-tax national income-Top 1\% share. http://wid.world/data/

Yamagishi, T., \& Mifune, N. (2016). Parochial altruism: does it explain modern human group psychology. Current Opinion in Psychology, 7, 39-43.

Zack-Williams, A. B. (2001). Child soldiers in the civil war in Sierra Leone. Review of African Political Economy, 28(87), 73-82.

Zizzo, D. J. (2003). Money burning and rank egalitarianism with random dictators. Economics Letters, 81(2), 263-266. 
Zizzo, D. J., \& Oswald, A. J. (2001). Are people willing to pay to reduce others' incomes?. 


\section{Tables}

Table 1: actions and payoffs in the IPD

\begin{tabular}{l|lll|lcc} 
& \multicolumn{2}{|l}{$\begin{array}{l}\text { Effect on } \\
\text { Ingroup member }\end{array}$} & & \multicolumn{3}{l}{ Outgroup member } \\
\hline Action & 1 (self) & 2 & 3 & 1 & 2 & 3 \\
\hline Keep & +1 & 0 & 0 & 0 & 0 & 0 \\
Attack & $+0,5$ & $+0,5$ & $+0,5$ & $-0,5$ & $-0,5$ & $-0,5$ \\
\hline
\end{tabular}

Note: The table is adapted from Weisel and Böhm (2015). It illustrates the effect of the subject decision to contribute one point to attack the outgroup on the subject payoff, the payoff of each of two other ingroup members, and that of the three outgroup members. 
Table 2: summary of the $2 \times 3$ experimental conditions

Assignment

\begin{tabular}{ccc}
\hline Experimental treatment & $\begin{array}{l}\text { The subject cannot contribute } \\
\text { more than } \beta \text { in attacks }\end{array}$ & $\begin{array}{l}\text { Each experimental session is randomly } \\
\text { assigned to a given treatment (for all 15 } \\
\text { subjects during all the game) }\end{array}$ \\
\hline$E D C$ & $\beta=10 \%$ of subject resources & $50.00 \%$ \\
UDC & $\beta=.00 \%$ \\
\hline Economic condition & The subject receives an & $\begin{array}{c}\text { Every 5 round, each group is randomly } \\
\text { assigned to a given condition }\end{array}$ \\
\hline Declining & $\alpha=-2 \%$ of subject resources & $35.70 \%{ }^{a}$ \\
Stable & $\alpha=+2 \%$ of subject resources & $30.08 \%{ }^{a}$ \\
Improving & $\alpha=+6 \%$ of subject resources & $34.22 \%{ }^{a}$ \\
\hline \hline
\end{tabular}

${ }^{a}$ Expresses the share of subjects assigned to the condition by round (subjects may have been be assigned to different conditions throughout the game) 
Table 3: mean level of individual attacks against an outgroup (and SD) by experimental

\begin{tabular}{|c|c|c|c|c|c|c|c|c|c|}
\hline \multirow{3}{*}{$\begin{array}{r}\text { Experimental } \\
\text { treatment } \\
\text { Outgroup } \\
\text { economic } \\
\text { condition }\end{array}$} & \multicolumn{8}{|c|}{ treatment } & \multirow{3}{*}{ All } \\
\hline & \multicolumn{4}{|c|}{ EDC treatment } & \multicolumn{4}{|c|}{ UDC treatment } & \\
\hline & Declining & Stable & Improving & All & Declining & Stable & Improving & All & \\
\hline $\begin{array}{c}\text { Any } \\
\text { outgroup }\end{array}$ & $\begin{array}{c}5.94 \\
(9.56)\end{array}$ & $\begin{array}{c}6.51 \\
(10.6)\end{array}$ & $\begin{array}{c}8.34 \\
(11.4)\end{array}$ & $\begin{array}{c}6.84 \\
(10.5)\end{array}$ & $\begin{array}{c}5.11 \\
(8.61)\end{array}$ & $\begin{array}{c}6.07 \\
(9.86)\end{array}$ & $\begin{array}{c}7.36 \\
(9.95)\end{array}$ & $\begin{array}{c}6.24 \\
(9.55)\end{array}$ & $\begin{array}{l}6.54 \\
(10)\end{array}$ \\
\hline $\begin{array}{l}\text { Richer } \\
\text { outgroup }\end{array}$ & $\begin{array}{c}7.14 \\
(10.5)\end{array}$ & $\begin{array}{c}7.1 \\
(11.1)\end{array}$ & $\begin{array}{l}9.59 \\
(12)\end{array}$ & $\begin{array}{c}8 \\
(11.3)\end{array}$ & $\begin{array}{c}5.24 \\
(8.02)\end{array}$ & $\begin{array}{c}6.58 \\
(9.53)\end{array}$ & $\begin{array}{c}6.66 \\
(9.06)\end{array}$ & $\begin{array}{c}6.33 \\
(9.01)\end{array}$ & $\begin{array}{c}7.15 \\
(10.2)\end{array}$ \\
\hline $\begin{array}{l}\text { Poorer } \\
\text { outgroup }\end{array}$ & $\begin{array}{c}5.07 \\
(8.75)\end{array}$ & $\begin{array}{l}5.92 \\
(10)\end{array}$ & $\begin{array}{c}6.55 \\
(10.1)\end{array}$ & $\begin{array}{c}5.7 \\
(9.51)\end{array}$ & $\begin{array}{c}5.04 \\
(8.88)\end{array}$ & $\begin{array}{c}5.52 \\
(10.2)\end{array}$ & $\begin{array}{c}8.59 \\
(11.2)\end{array}$ & $\begin{array}{c}6.16 \\
(10.1)\end{array}$ & $\begin{array}{c}5.93 \\
(9.79)\end{array}$ \\
\hline
\end{tabular}




\section{Table 4: standardized coefficients from multilevel negative binomial regression analyses of the level of individual attacks against an outgroup}

\begin{tabular}{|c|c|c|c|c|}
\hline VARIABLES & I & II & III & IV \\
\hline Richer outgroup & $\begin{array}{r}0.753 * * * \\
(0.0420)\end{array}$ & $\begin{array}{r}0.864 * * * \\
(0.0539)\end{array}$ & $\begin{array}{l}0.763 * * * \\
(0.0477)\end{array}$ & $\begin{array}{r}0.789 * * * \\
(0.0611)\end{array}$ \\
\hline UDC treatment & & $\begin{array}{c}0.0276 \\
(0.0813)\end{array}$ & & $\begin{array}{l}-0.0689 \\
(0.0852)\end{array}$ \\
\hline Richer outgroup $\times$ UDC treatment & & $\begin{array}{c}-0.226 * * * \\
(0.0681)\end{array}$ & & $\begin{array}{l}-0.0622 \\
(0.0812)\end{array}$ \\
\hline Improving outgroup condition & & & $\begin{array}{r}0.313 * * * \\
(0.0481)\end{array}$ & $\begin{array}{c}0.152 * \\
(0.0698)\end{array}$ \\
\hline Improving outgroup condition $\times$ Richer outgroup & & & $\begin{array}{l}-0.165 * * \\
(0.0639)\end{array}$ & $\begin{array}{c}0.107 \\
(0.0927)\end{array}$ \\
\hline UDC treatment $\times$ Improving outgroup condition & & & & $\begin{array}{l}0.287 * * \\
(0.0958)\end{array}$ \\
\hline $\begin{array}{l}\text { Richer outgroup } \times \text { UDC treatment } \times \text { Improving outgroup } \\
\text { condition }\end{array}$ & & & & $\begin{array}{c}-0.485 * * * \\
(0.128)\end{array}$ \\
\hline Attacks by the outgroup against the ingroup (t-1) & $\begin{array}{r}0.328 * * * \\
(0.0164)\end{array}$ & $\begin{array}{r}0.330^{* * *} \\
(0.0164)\end{array}$ & $\begin{array}{r}0.321 * * * \\
(0.0163)\end{array}$ & $\begin{array}{l}0.322 * * * \\
(0.0163)\end{array}$ \\
\hline Ingroup rank (richest as reference) & & & & \\
\hline Second & $\begin{array}{c}-0.285 * * * \\
(0.0572)\end{array}$ & $\begin{array}{c}-0.300 * * * \\
(0.0572)\end{array}$ & $\begin{array}{c}-0.285 * * * \\
(0.0571)\end{array}$ & $\begin{array}{c}-0.300 * * * \\
(0.0571)\end{array}$ \\
\hline Third & $\begin{array}{l}-0.534 * * * \\
(0.0622)\end{array}$ & $\begin{array}{c}-0.543 * * * \\
(0.0621)\end{array}$ & $\begin{array}{c}-0.525 * * * \\
(0.0621)\end{array}$ & $\begin{array}{c}-0.534 * * * \\
(0.0619)\end{array}$ \\
\hline Fourth & $\begin{array}{c}-0.652 * * * \\
(0.0659)\end{array}$ & $\begin{array}{c}-0.662 * * * \\
(0.0658)\end{array}$ & $\begin{array}{c}-0.629 * * * \\
(0.0658)\end{array}$ & $\begin{array}{c}-0.638 * * * \\
(0.0658)\end{array}$ \\
\hline Poorest & $\begin{array}{c}-0.991 * * * \\
(0.0820)\end{array}$ & $\begin{array}{c}-1.008 * * * \\
(0.0819)\end{array}$ & $\begin{array}{c}-0.963 * * * \\
(0.0819)\end{array}$ & $\begin{array}{c}-0.970 * * * \\
(0.0818)\end{array}$ \\
\hline Constant & $\begin{array}{l}1.761 * * * \\
(0.0538)\end{array}$ & $\begin{array}{c}1.758 * * * \\
(0.0665)\end{array}$ & $\begin{array}{l}1.668 * * * \\
(0.0554)\end{array}$ & $\begin{array}{c}1.713 * * * \\
(0.0687)\end{array}$ \\
\hline $\ln ($ alpha $)$ & $\begin{array}{c}1.098 * * * \\
(0.0146)\end{array}$ & $\begin{array}{c}1.098 * * * \\
(0.0146)\end{array}$ & $\begin{array}{c}1.093 * * * \\
(0.0146)\end{array}$ & $\begin{array}{c}1.091 * * * \\
(0.0146)\end{array}$ \\
\hline var(subjects) & $\begin{array}{c}0.356 * * * \\
(0.0375)\end{array}$ & $\begin{array}{c}0.345^{* * *} \\
(0.0367)\end{array}$ & $\begin{array}{c}0.358 * * * \\
(0.0376)\end{array}$ & $\begin{array}{c}0.348 * * * \\
(0.0369)\end{array}$ \\
\hline Observations $^{\mathrm{a}, \mathrm{b}}$ & 16,416 & 16,416 & 16,416 & 16,416 \\
\hline Number of subjects & 300 & 300 & 300 & 300 \\
\hline
\end{tabular}

${ }^{a}$ Observations are all subject-outgroup dyads for each round of the game, excluding the first round due to the inclusion of the "Attacks by the outgroup against the ingroup (t-1)" variable. Rounds in which at least one group died are excluded. ${ }^{b}$ Four ingroup-outgroup dyads are excluded because they had the same level of resources, meaning that there was no richer / poorer group. As each ingroup gathers three subjects, twelve subject-outgroup dyads are excluded from the models. 
Table 5: standardized coefficients from multilevel negative binomial regression analyses of the level of individual attacks against an outgroup

\begin{tabular}{|c|c|c|c|c|c|c|}
\hline VARIABLES & I & II & III & IV & $\mathrm{V}$ & VI \\
\hline \multicolumn{7}{|l|}{ Subject-level variables } \\
\hline Perceived self cooperation & $\begin{array}{c}0.127 * * * \\
(0.0283)\end{array}$ & $\begin{array}{c}0.170 * * * \\
(0.0370)\end{array}$ & $\begin{array}{c}0.144 * * * \\
(0.0344)\end{array}$ & $\begin{array}{c}0.143 * * * \\
(0.0344)\end{array}$ & $\begin{array}{c}0.117 * * * \\
(0.0272)\end{array}$ & $\begin{array}{c}0.160 * * * \\
(0.0354)\end{array}$ \\
\hline Richer outgroup $\times$ Perceived self cooperation & & $\begin{array}{c}-0.0961^{*} \\
(0.0473)\end{array}$ & & & & $\begin{array}{c}-0.0885 * \\
(0.0438)\end{array}$ \\
\hline Left right self position & $\begin{array}{l}-0.0646^{*} \\
(0.0322)\end{array}$ & $\begin{array}{l}-0.0452 \\
(0.0396)\end{array}$ & $\begin{array}{c}-0.00424 \\
(0.0415)\end{array}$ & $\begin{array}{c}-0.0475 \\
(0.0392)\end{array}$ & $\begin{array}{l}-0.0653 * \\
(0.0309)\end{array}$ & $\begin{array}{l}-0.0264 \\
(0.0407)\end{array}$ \\
\hline Richer outgroup $\times$ Left right self position & & & $\begin{array}{l}-0.141 * * \\
(0.0452)\end{array}$ & & & $\begin{array}{l}-0.0725 \\
(0.0484)\end{array}$ \\
\hline Social Dominance Orientation & $\begin{array}{l}0.0672 * \\
(0.0325)\end{array}$ & $\begin{array}{l}0.0889 * \\
(0.0399)\end{array}$ & $\begin{array}{l}0.0876^{*} \\
(0.0395)\end{array}$ & $\begin{array}{c}0.133 * * \\
(0.0416)\end{array}$ & $\begin{array}{l}0.0676^{*} \\
(0.0312)\end{array}$ & $\begin{array}{l}0.121 * * \\
(0.0407)\end{array}$ \\
\hline Richer outgroup $\times$ Social Dominance Orientation & & & & $\begin{array}{c}-0.152^{* * *} \\
(0.0447)\end{array}$ & & $\begin{array}{c}-0.115^{*} \\
(0.0482)\end{array}$ \\
\hline Male (female as reference) & $\begin{array}{c}-0.0444 \\
(0.0588)\end{array}$ & $\begin{array}{c}-0.0584 \\
(0.0717)\end{array}$ & $\begin{array}{l}-0.0585 \\
(0.0710)\end{array}$ & $\begin{array}{l}-0.0541 \\
(0.0710)\end{array}$ & $\begin{array}{l}-0.0306 \\
(0.0565)\end{array}$ & $\begin{array}{l}-0.0415 \\
(0.0676)\end{array}$ \\
\hline Age & $\begin{array}{c}0.0686 \\
(0.0464)\end{array}$ & $\begin{array}{c}0.0789 \\
(0.0560)\end{array}$ & $\begin{array}{c}0.0758 \\
(0.0555)\end{array}$ & $\begin{array}{c}0.0749 \\
(0.0555)\end{array}$ & $\begin{array}{l}0.0767+ \\
(0.0446)\end{array}$ & $\begin{array}{c}0.0797 \\
(0.0529)\end{array}$ \\
\hline \multicolumn{7}{|l|}{ Education (less than highschool as reference) } \\
\hline Highschool & $\begin{array}{c}0.0124 \\
(0.0961)\end{array}$ & $\begin{array}{c}-0.0362 \\
(0.118)\end{array}$ & $\begin{array}{c}-0.0260 \\
(0.117)\end{array}$ & $\begin{array}{c}-0.0117 \\
(0.117)\end{array}$ & $\begin{array}{c}-0.00701 \\
(0.0924)\end{array}$ & $\begin{array}{l}-0.0267 \\
(0.111)\end{array}$ \\
\hline Bachelor & $\begin{array}{c}0.0431 \\
(0.0945)\end{array}$ & $\begin{array}{c}-0.0349 \\
(0.116)\end{array}$ & $\begin{array}{c}-0.0242 \\
(0.114)\end{array}$ & $\begin{array}{r}-0.0153 \\
(0.114)\end{array}$ & $\begin{array}{c}0.0355 \\
(0.0908)\end{array}$ & $\begin{array}{c}-0.0175 \\
(0.109)\end{array}$ \\
\hline Master & $\begin{array}{l}0.0387 \\
(0.105)\end{array}$ & $\begin{array}{l}-0.0131 \\
(0.129)\end{array}$ & $\begin{array}{c}-0.0109 \\
(0.127)\end{array}$ & $\begin{array}{c}0.00152 \\
(0.127)\end{array}$ & $\begin{array}{l}0.0155 \\
(0.101)\end{array}$ & $\begin{array}{l}-0.0221 \\
(0.121)\end{array}$ \\
\hline Phd & $\begin{array}{l}-0.0982 \\
(0.0952)\end{array}$ & $\begin{array}{c}-0.197+ \\
(0.117)\end{array}$ & $\begin{array}{c}-0.186 \\
(0.116)\end{array}$ & $\begin{array}{l}-0.185 \\
(0.116)\end{array}$ & $\begin{array}{c}-0.112 \\
(0.0915)\end{array}$ & $\begin{array}{c}-0.181+ \\
(0.110)\end{array}$ \\
\hline \multicolumn{7}{|l|}{ Working status (student as reference) } \\
\hline Working & $\begin{array}{l}-0.102 \\
(0.141)\end{array}$ & $\begin{array}{l}-0.177 \\
(0.171)\end{array}$ & $\begin{array}{l}-0.161 \\
(0.169)\end{array}$ & $\begin{array}{l}-0.146 \\
(0.169)\end{array}$ & $\begin{array}{l}-0.123 \\
(0.136)\end{array}$ & $\begin{array}{l}-0.161 \\
(0.162)\end{array}$ \\
\hline Not working & $\begin{array}{c}-0.0716 \\
(0.109)\end{array}$ & $\begin{array}{l}-0.109 \\
(0.131)\end{array}$ & $\begin{array}{l}-0.0945 \\
(0.130)\end{array}$ & $\begin{array}{l}-0.0927 \\
(0.130)\end{array}$ & $\begin{array}{l}-0.100 \\
(0.104)\end{array}$ & $\begin{array}{l}-0.112 \\
(0.124)\end{array}$ \\
\hline \multicolumn{7}{|l|}{ Subject-outgroup-round variables } \\
\hline Richer outgroup & $\begin{array}{c}0.380 * * * \\
(0.0472)\end{array}$ & $\begin{array}{c}0.318 * * * \\
(0.0594)\end{array}$ & $\begin{array}{c}0.316^{* * *} \\
(0.0589)\end{array}$ & $\begin{array}{c}0.311 * * * \\
(0.0586)\end{array}$ & $\begin{array}{c}0.294 * * * \\
(0.0486)\end{array}$ & $\begin{array}{c}0.259 * * * \\
(0.0571)\end{array}$ \\
\hline Outgroup resources & $\begin{array}{c}0.228 * * * \\
(0.0216)\end{array}$ & $\begin{array}{c}0.278 * * * \\
(0.0235)\end{array}$ & $\begin{array}{c}0.279 * * * \\
(0.0235)\end{array}$ & $\begin{array}{c}0.279 * * * \\
(0.0234)\end{array}$ & $\begin{array}{c}0.281 * * * \\
(0.0227)\end{array}$ & $\begin{array}{c}0.307 * * * \\
(0.0236)\end{array}$ \\
\hline Outgroup variation due to economic condition & $\begin{array}{c}0.0641 * * * \\
(0.0154)\end{array}$ & $\begin{array}{c}0.0616^{* * *} * \\
(0.0155)\end{array}$ & $\begin{array}{c}0.0619 * * * \\
(0.0155)\end{array}$ & $\begin{array}{c}0.0616^{* * *} * \\
(0.0155)\end{array}$ & $\begin{array}{c}0.0663 * * * \\
(0.0154)\end{array}$ & $\begin{array}{c}0.0635 * * * \\
(0.0155)\end{array}$ \\
\hline Inequality & $\begin{array}{c}-0.0692 * * \\
(0.0213)\end{array}$ & $\begin{array}{c}-0.0513^{*} \\
(0.0231)\end{array}$ & $\begin{array}{l}-0.0511^{*} \\
(0.0230)\end{array}$ & $\begin{array}{c}-0.0500^{*} \\
(0.0230)\end{array}$ & $\begin{array}{c}0.0441 \\
(0.0274)\end{array}$ & $\begin{array}{c}0.0404 \\
(0.0284)\end{array}$ \\
\hline Richer outgroup $\times$ Inequality & & & & & $\begin{array}{c}-0.243 * * * \\
(0.0348)\end{array}$ & $\begin{array}{c}-0.228 * * * \\
(0.0394)\end{array}$ \\
\hline UDC treatment & $\begin{array}{l}-0.111+ \\
(0.0582)\end{array}$ & $\begin{array}{l}-0.0600 \\
(0.0704)\end{array}$ & $\begin{array}{l}-0.0619 \\
(0.0698)\end{array}$ & $\begin{array}{l}-0.0696 \\
(0.0697)\end{array}$ & $\begin{array}{l}-0.111^{*} \\
(0.0560)\end{array}$ & $\begin{array}{l}-0.0822 \\
(0.0665)\end{array}$ \\
\hline Attacks by the subject against the outgroup at $t-1$ & $\begin{array}{c}0.343 * * * \\
(0.0158)\end{array}$ & $\begin{array}{c}0.322 * * * \\
(0.0159)\end{array}$ & $\begin{array}{c}0.322 * * * \\
(0.0159)\end{array}$ & $\begin{array}{c}0.323 * * * \\
(0.0159)\end{array}$ & $\begin{array}{c}0.341 * * * \\
(0.0158)\end{array}$ & $\begin{array}{c}0.323 * * * \\
(0.0159)\end{array}$ \\
\hline Attacks by the outgroup against the ingroup at $t-1$ & $\begin{array}{l}0.233 * * * \\
(0.0154)\end{array}$ & $\begin{array}{l}0.239 * * * \\
(0.0155)\end{array}$ & $\begin{array}{l}0.239 * * * \\
(0.0155)\end{array}$ & $\begin{array}{l}0.239 * * * \\
(0.0155)\end{array}$ & $\begin{array}{l}0.237 * * * \\
(0.0154)\end{array}$ & $\begin{array}{l}0.242 * * * \\
(0.0155)\end{array}$ \\
\hline Attacks by other ingroup subjects at t-1 & $\begin{array}{c}0.253 * * * \\
(0.0230)\end{array}$ & $\begin{array}{c}0.229 * * * \\
(0.0240)\end{array}$ & $\begin{array}{c}0.229 * * * \\
(0.0240)\end{array}$ & $\begin{array}{c}0.230 * * * \\
(0.0240)\end{array}$ & $\begin{array}{c}0.251 * * * \\
(0.0228)\end{array}$ & $\begin{array}{c}0.229 * * * \\
(0.0238)\end{array}$ \\
\hline Subject resources & $\begin{array}{l}-0.0133 \\
(0.0275)\end{array}$ & $\begin{array}{l}-0.0186 \\
(0.0293)\end{array}$ & $\begin{array}{l}-0.0193 \\
(0.0292)\end{array}$ & $\begin{array}{l}-0.0197 \\
(0.0292)\end{array}$ & $\begin{array}{l}-0.0696 * \\
(0.0282)\end{array}$ & $\begin{array}{c}-0.0583 * \\
(0.0297)\end{array}$ \\
\hline & & & & & & \\
\hline Second & $\begin{array}{c}-0.182 * * * \\
(0.0538)\end{array}$ & $\begin{array}{c}-0.249 * * * \\
(0.0558)\end{array}$ & $\begin{array}{c}-0.250 * * * \\
(0.0557)\end{array}$ & $\begin{array}{c}-0.249 * * * \\
(0.0557)\end{array}$ & $\begin{array}{c}-0.210 * * * \\
(0.0533)\end{array}$ & $\begin{array}{c}-0.261 * * * \\
(0.0550)\end{array}$ \\
\hline
\end{tabular}




\begin{tabular}{|c|c|c|c|c|c|c|}
\hline Third & $\begin{array}{c}-0.312 * * * \\
(0.0591)\end{array}$ & $\begin{array}{c}-0.377 * * * \\
(0.0610)\end{array}$ & $\begin{array}{c}-0.378 * * * \\
(0.0609)\end{array}$ & $\begin{array}{c}-0.377 * * * \\
(0.0609)\end{array}$ & $\begin{array}{c}-0.330 * * * \\
(0.0585)\end{array}$ & $\begin{array}{c}-0.382 * * * \\
(0.0602)\end{array}$ \\
\hline Fourth & $\begin{array}{c}-0.308 * * * \\
(0.0638)\end{array}$ & $\begin{array}{c}-0.370 * * * \\
(0.0668)\end{array}$ & $\begin{array}{c}-0.374 * * * \\
(0.0666)\end{array}$ & $\begin{array}{c}-0.369^{* * *} \\
(0.0667)\end{array}$ & $\begin{array}{c}-0.342 * * * \\
(0.0634)\end{array}$ & $\begin{array}{c}-0.387 * * * \\
(0.0659)\end{array}$ \\
\hline Poorest & $\begin{array}{c}-0.508 * * * \\
(0.0789)\end{array}$ & $\begin{array}{c}-0.516^{* * *} \\
(0.0866)\end{array}$ & $\begin{array}{c}-0.515^{* * *} * \\
(0.0863)\end{array}$ & $\begin{array}{c}-0.505^{* * * *} \\
(0.0863)\end{array}$ & $\begin{array}{c}-0.587 * * * \\
(0.0790)\end{array}$ & $\begin{array}{c}-0.561 * * * \\
(0.0855)\end{array}$ \\
\hline Constant & $\begin{array}{c}1.755^{* * *} \\
(0.128)\end{array}$ & $\begin{array}{c}1.874 * * * \\
(0.155)\end{array}$ & $\begin{array}{c}1.870 * * * \\
(0.153)\end{array}$ & $\begin{array}{c}1.859 * * * \\
(0.153)\end{array}$ & $\begin{array}{c}1.829 * * * \\
(0.124)\end{array}$ & $\begin{array}{c}1.902 * * * \\
(0.146)\end{array}$ \\
\hline $\ln ($ alpha) & $\begin{array}{c}1.012 * * * \\
(0.0149)\end{array}$ & $\begin{array}{c}0.979 * * * \\
(0.0154)\end{array}$ & $\begin{array}{c}0.980 * * * \\
(0.0154)\end{array}$ & $\begin{array}{c}0.980 * * * \\
(0.0154)\end{array}$ & $\begin{array}{c}1.009 * * * \\
(0.0150)\end{array}$ & $\begin{array}{c}0.981 * * * \\
(0.0155)\end{array}$ \\
\hline var(subjects) & $\begin{array}{l}0.165 * * * \\
(0.0225)\end{array}$ & $\begin{array}{c}0.224 * * * \\
(0.0321)\end{array}$ & $\begin{array}{c}0.219 * * * \\
(0.0316)\end{array}$ & $\begin{array}{c}0.219 * * * \\
(0.0316)\end{array}$ & $\begin{array}{c}0.148 * * * \\
(0.0210)\end{array}$ & $\begin{array}{c}0.197 * * * \\
(0.0294)\end{array}$ \\
\hline $\operatorname{var}(\text { Richer outgroup })^{c}$ & & $\begin{array}{c}0.276 * * * \\
(0.0552)\end{array}$ & $\begin{array}{c}0.261 * * * \\
(0.0541)\end{array}$ & $\begin{array}{c}0.254 * * * \\
(0.0535)\end{array}$ & & $\begin{array}{c}0.193 * * * \\
(0.0462)\end{array}$ \\
\hline Observations $^{\mathrm{a}, \mathrm{b}}$ & 16,416 & 16,416 & 16,416 & 16,416 & 16,416 & 16,416 \\
\hline Number of subjects & 300 & 300 & 300 & 300 & 300 & 300 \\
\hline
\end{tabular}

Standard errors in parentheses
$* * * \mathrm{p}<0.001,{ }^{* *} \mathrm{p}<0.01,{ }^{*} \mathrm{p}<0.05,+\mathrm{p}<0.1$

${ }^{a}$ Observations are all subject - outgroup dyads for each round of the game, excluding the first round due to the inclusion of the "Attacks by the outgroup against the ingroup (t-1)" variable. Rounds in which at least one group died were excluded.

${ }^{b}$ Four ingroup-outgroup dyads are excluded because they had the same level of resources, meaning that there was no richer / poorer group. As each ingroup gathers three subjects, twelve subject-outgroup dyads are excluded from the models.

'In models II, III, IV and VI, we test for cross-level interactions between subject-level (level-2) variables and a subject-round-outgroup (level-1) variable - here, the "Richer outgroup" variable. In these models, we included a random slope for the level-1 variable as recommended by Snijders and Bosker (2012). See also Heisig and Schaeffer (2019). 
Table 6: unstandardized coefficients from negative binomial regression analyses of the number of terrorist attacks

\begin{tabular}{|c|c|c|c|c|c|c|}
\hline \multirow{3}{*}{ Share of income owned by $1 \%$ richest $(\mathrm{t}-1)$} & \multirow{2}{*}{\multicolumn{3}{|c|}{$\begin{array}{l}\text { I } \quad \text { II } \quad \text { III } \\
\text { Left-wing terrorist attacks } \\
\end{array}$}} & \multirow{2}{*}{\multicolumn{3}{|c|}{$\begin{array}{lcc}\text { IV } & \text { V } & \text { VI } \\
\text { Right-wing terrorist attacks }\end{array}$}} \\
\hline & & & & & & \\
\hline & $\begin{array}{c}-9.272 * * * \\
(2.020)\end{array}$ & $\begin{array}{c}-18.19^{* * *} \\
(3.682)\end{array}$ & $\begin{array}{l}-9.168 * \\
(4.042)\end{array}$ & $\begin{array}{l}-1.041 \\
(2.584)\end{array}$ & $\begin{array}{c}5.213 \\
(6.317)\end{array}$ & $\begin{array}{l}18.72 * * \\
(7.176)\end{array}$ \\
\hline \multirow[t]{2}{*}{$\log$ Population (t-1) } & $1.029 * * *$ & $8.976 * * *$ & $11.04 * * *$ & $0.583 * * *$ & $4.928^{* *}$ & $8.052 * * *$ \\
\hline & $(0.0951)$ & $(1.104)$ & $(1.175)$ & $(0.113)$ & $(1.570)$ & $(1.781)$ \\
\hline Youth population share (t-1) & $\begin{array}{c}18.65^{* *} \\
(6.302)\end{array}$ & $\begin{array}{c}36.62 * * * \\
(6.900)\end{array}$ & $\begin{array}{l}16.50^{*} \\
(7.036)\end{array}$ & $\begin{array}{l}1.547 \\
(7.640)\end{array}$ & $\begin{array}{c}35.78^{* * *} \\
(9.470)\end{array}$ & $\begin{array}{l}6.143 \\
(10.22)\end{array}$ \\
\hline Ethno-political exclusion (t-1) & $\begin{array}{c}3.534 * * * \\
(0.747)\end{array}$ & $\begin{array}{l}2.912 * * * \\
(0.801)\end{array}$ & $\begin{array}{l}1.888^{*} \\
(0.944)\end{array}$ & $\begin{array}{l}0.0644 \\
(0.712)\end{array}$ & $\begin{array}{c}0.692 \\
(0.992)\end{array}$ & $\begin{array}{l}1.416 \\
(1.027)\end{array}$ \\
\hline Democracy (t-1) & $\begin{array}{c}0.109^{*} \\
(0.0465)\end{array}$ & $\begin{array}{c}-0.547^{* * * *} \\
(0.148)\end{array}$ & $\begin{array}{c}-0.499 * * * \\
(0.140)\end{array}$ & $\begin{array}{l}0.00588 \\
(0.0587)\end{array}$ & $\begin{array}{l}-0.123 \\
(0.111)\end{array}$ & $\begin{array}{l}-0.132 \\
(0.112)\end{array}$ \\
\hline Regime durability (t-1) & $\begin{array}{c}-0.00560^{* *} \\
(0.00186)\end{array}$ & $\begin{array}{l}0.0240^{*} \\
(0.0105)\end{array}$ & $\begin{array}{c}0.0361 * * \\
(0.0120)\end{array}$ & $\begin{array}{c}0.00288 \\
(0.00244)\end{array}$ & $\begin{array}{c}0.0151 \\
(0.0124)\end{array}$ & $\begin{array}{l}0.00492 \\
(0.0124)\end{array}$ \\
\hline Government size $(\mathrm{t}-1)$ & $\begin{array}{l}0.407 \\
(1.051)\end{array}$ & $\begin{array}{l}-6.104 * * \\
(2.046)\end{array}$ & $\begin{array}{l}-4.017^{*} \\
(1.983)\end{array}$ & $\begin{array}{l}4.058 * * \\
(1.462)\end{array}$ & $\begin{array}{l}-0.113 \\
(3.053)\end{array}$ & $\begin{array}{l}2.948 \\
(3.271)\end{array}$ \\
\hline Civil war (t-1) & $\begin{array}{l}-0.478^{*} \\
(0.223)\end{array}$ & $\begin{array}{l}-0.129 \\
(0.207)\end{array}$ & $\begin{array}{l}-0.208 \\
(0.204)\end{array}$ & $\begin{array}{c}-5.173 \\
(33,388)\end{array}$ & $\begin{array}{l}-3.651 \\
(1,017)\end{array}$ & $\begin{array}{l}-3.352 \\
(501.1)\end{array}$ \\
\hline log GDP per capita (t-1) & $\begin{array}{c}0.176+ \\
(0.0972)\end{array}$ & $\begin{array}{l}-0.956^{* * *} \\
(0.214)\end{array}$ & $\begin{array}{l}0.186 \\
(0.393)\end{array}$ & $\begin{array}{l}-0.144 \\
(0.136)\end{array}$ & $\begin{array}{c}-0.938^{* *} \\
(0.290)\end{array}$ & $\begin{array}{l}-0.167 \\
(0.573)\end{array}$ \\
\hline GDP growth over 5 years $(\mathrm{t}-1)$ & $\begin{array}{l}-0.451 \\
(1.026)\end{array}$ & $\begin{array}{c}1.696 \\
(1.075)\end{array}$ & $\begin{array}{c}1.176 \\
(1.251)\end{array}$ & $\begin{array}{l}-2.691^{*} \\
(1.191)\end{array}$ & $\begin{array}{l}-2.771+ \\
(1.466)\end{array}$ & $\begin{array}{c}-5.507 * * \\
(1.697)\end{array}$ \\
\hline Dependent variable (t-1) & $\begin{array}{c}0.0467 * * * \\
(0.00442)\end{array}$ & $\begin{array}{c}0.0136 * * * \\
(0.00218)\end{array}$ & $\begin{array}{c}0.0114 * * * \\
(0.00202)\end{array}$ & $\begin{array}{c}0.248 * * * \\
(0.0289)\end{array}$ & $\begin{array}{c}0.118^{* * *} \\
(0.0248)\end{array}$ & $\begin{array}{r}0.121 * * * \\
(0.0217)\end{array}$ \\
\hline Country fixed effects & No & Yes & Yes & No & Yes & Yes \\
\hline Year fixed effects & No & No & Yes & $\begin{array}{c}\text { No } \\
-\end{array}$ & No & $\begin{array}{c}\text { Yes } \\
-\end{array}$ \\
\hline Constant & $\begin{array}{c}-21.97 * * * \\
(2.382)\end{array}$ & $\begin{array}{c}-142.3^{* * *} \\
(17.41)\end{array}$ & $\begin{array}{c}-186.4 * * * \\
(20.39)\end{array}$ & $\begin{array}{c}11.33 * * * \\
(3.085)\end{array}$ & $\begin{array}{c}-81.85 * * \\
(25.48)\end{array}$ & $\begin{array}{c}136.7 * * * \\
(31.34)\end{array}$ \\
\hline Observations & 652 & 652 & 652 & 652 & 652 & 652 \\
\hline
\end{tabular}

Standard errors in parentheses

$* * * \mathrm{p}<0.001, * * \mathrm{p}<0.01, * \mathrm{p}<0.05,+\mathrm{p}<0.1$ 
Figure 1: screenshots of the interface

\section{(a) During the round}

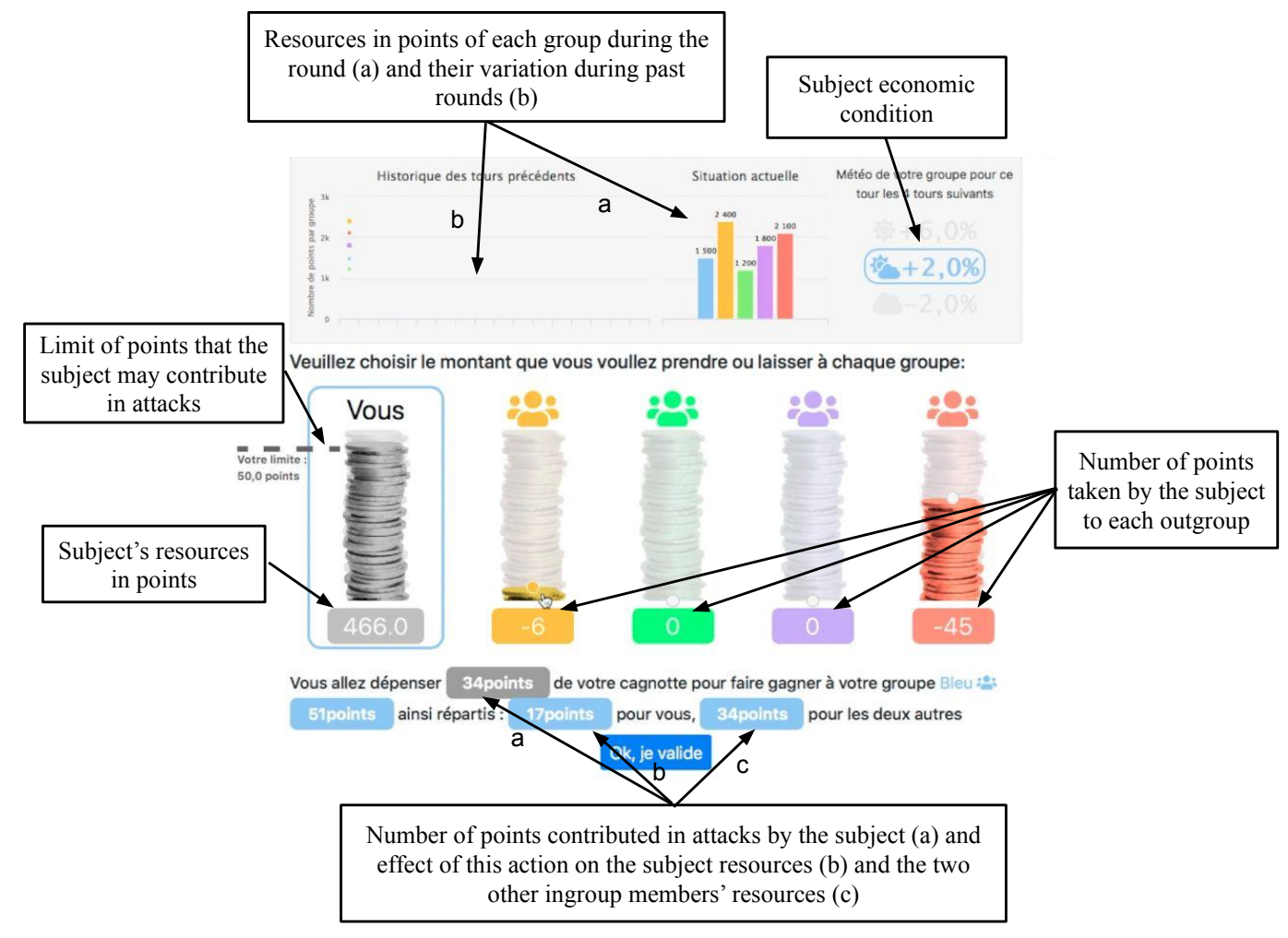

(b) After the round

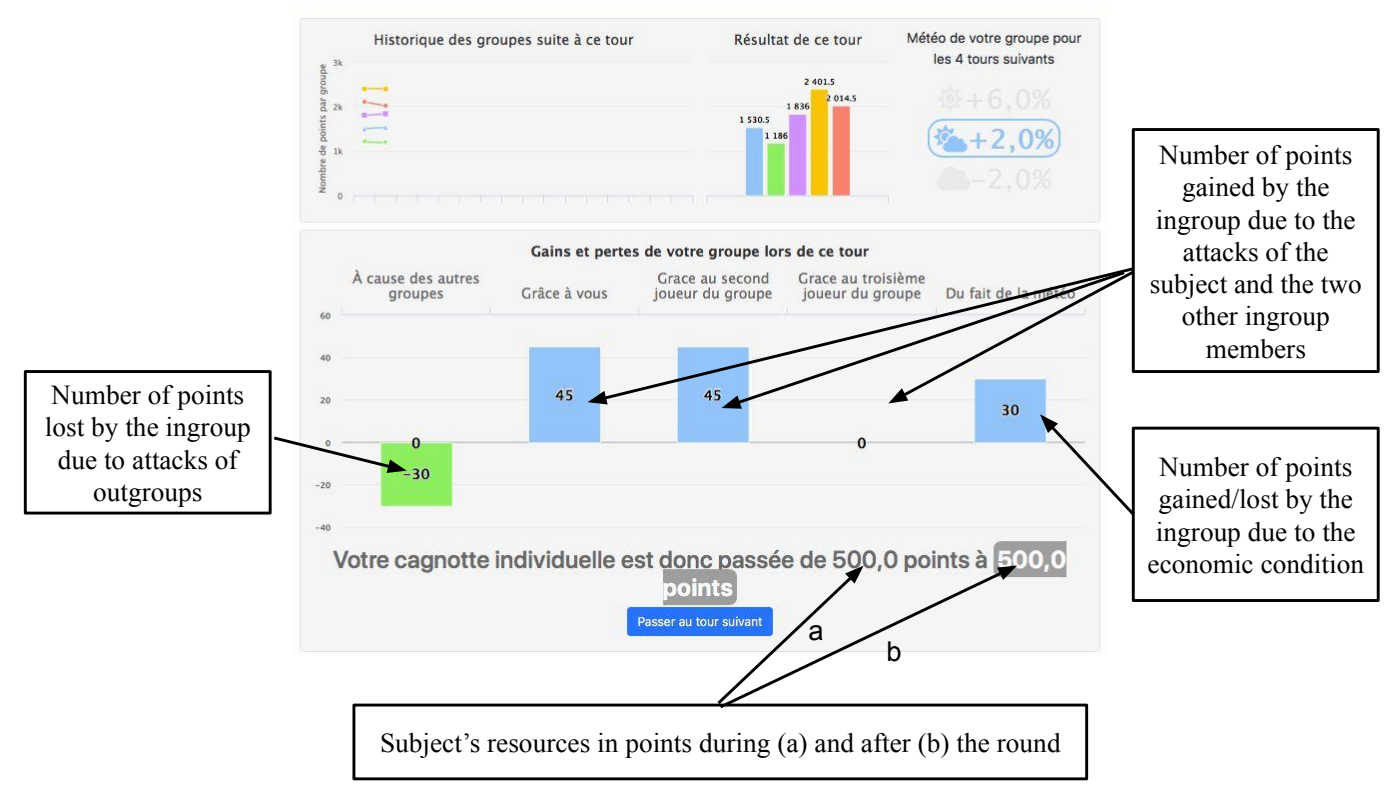


Figure 2: distribution of the level of individual attacks against an outgroup by treatment and round

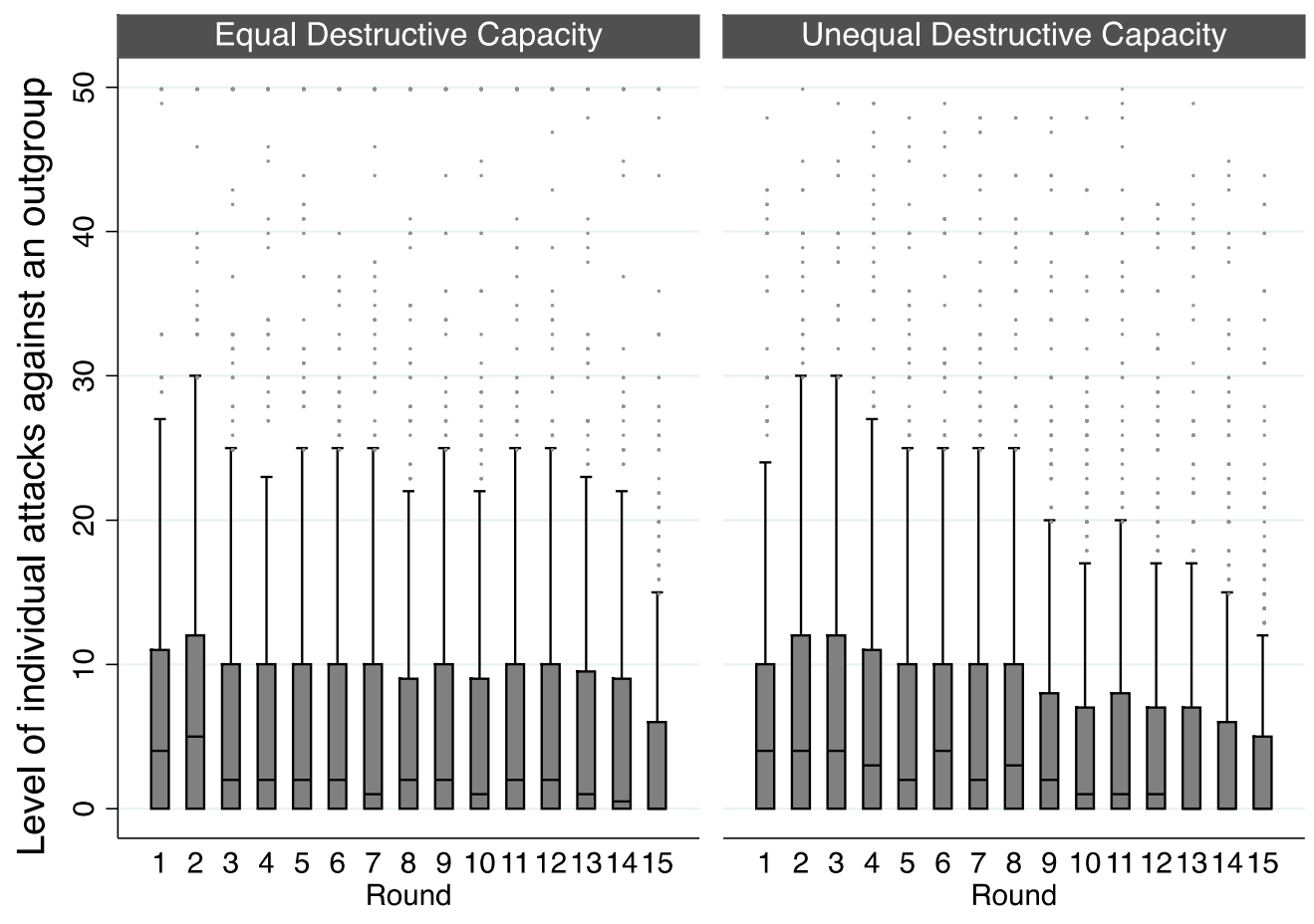

Figure note: for visual readability, outliers with more than 50 points contributed in attacks against an ingroup do not appear in the figure (45 observations in the UDC treatment, i.e.

$0.26 \%$ of the sample) 
Figure 3: mean resources of the groups by treatment and round

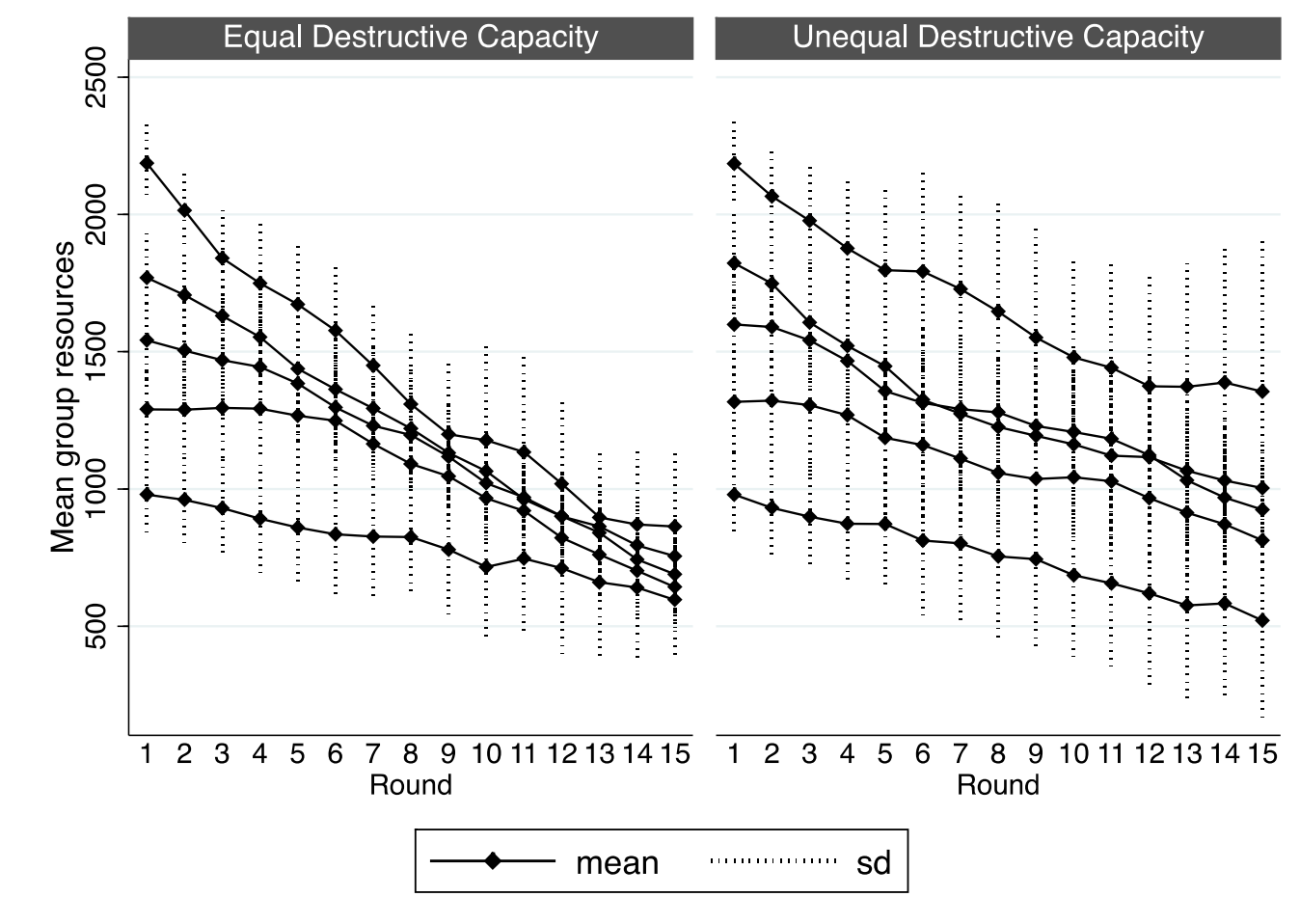

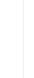


Figure 4: distribution of the level of individual attacks against an outgroup depending on the experimental treatment and the outgroup economic condition

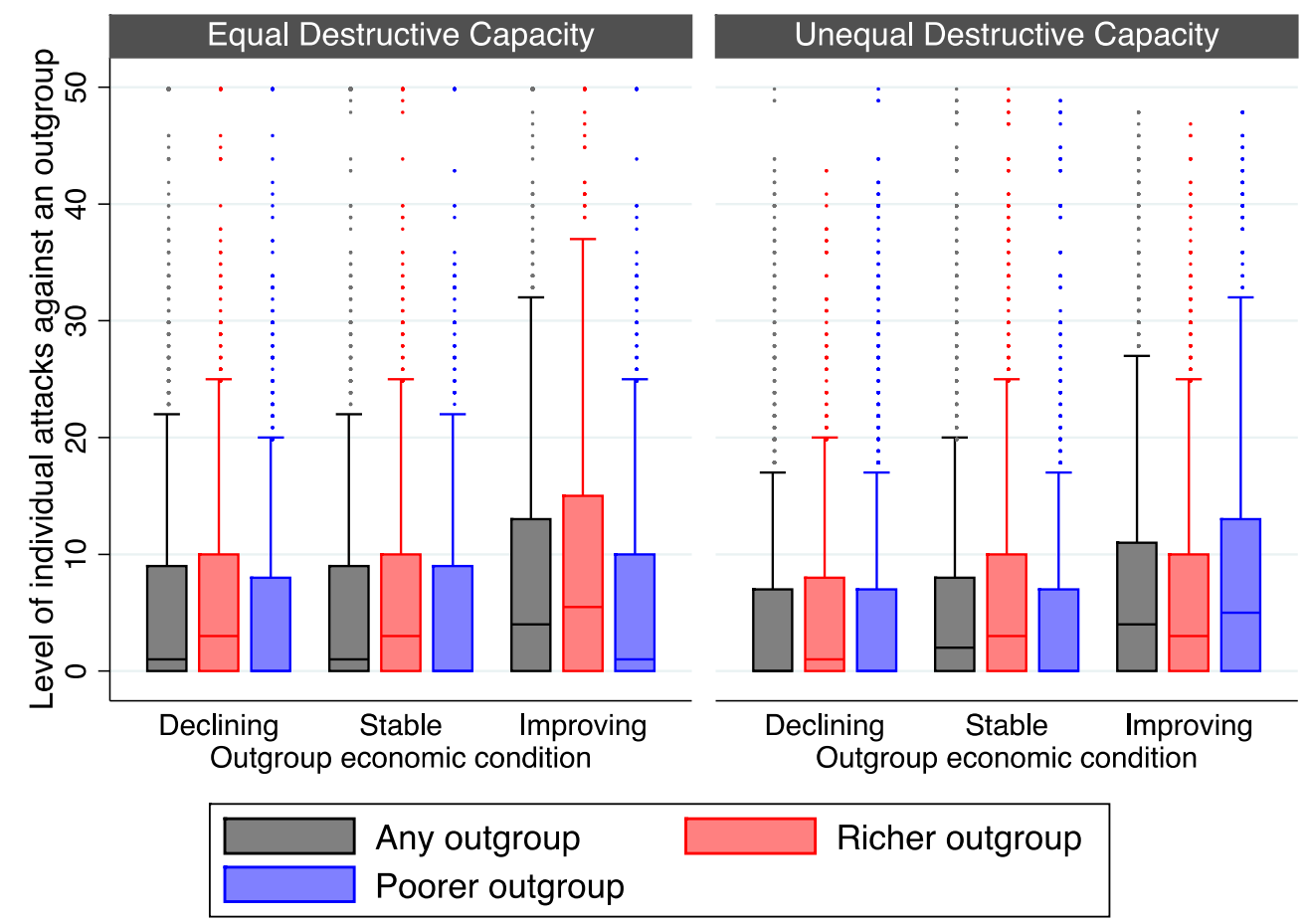

Figure note: for visual readability, outliers with more than 50 points contributed in attacks against an ingroup do not appear in the figure (45 observations in the UDC treatment, i.e.

$0.26 \%$ of the sample) 
Figure 5: level of individual attacks against an outgroup depending on the experimental treatment and the outgroup resources, quadratic fit (with 95\% CI)

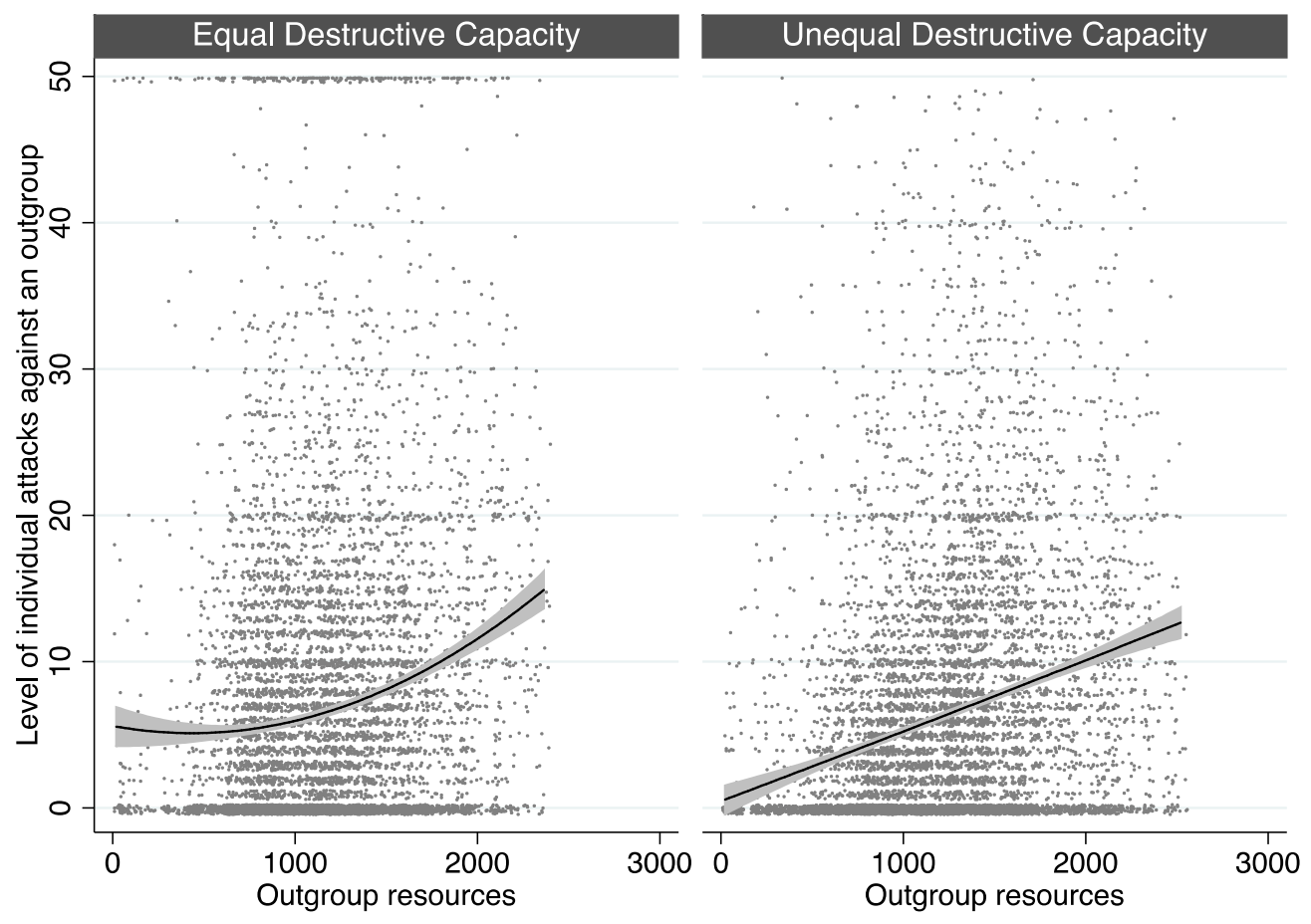

Figure note: for visual readability, outliers with more than 50 points contributed in attacks against an ingroup do not appear in the figure (45 observations in the UDC treatment, i.e. $0.26 \%$ of the sample) 
Figure 6: mean level of individual attacks against an outgroup depending on the treatment and the outgroup economic condition, predicted by model IV of Table 4

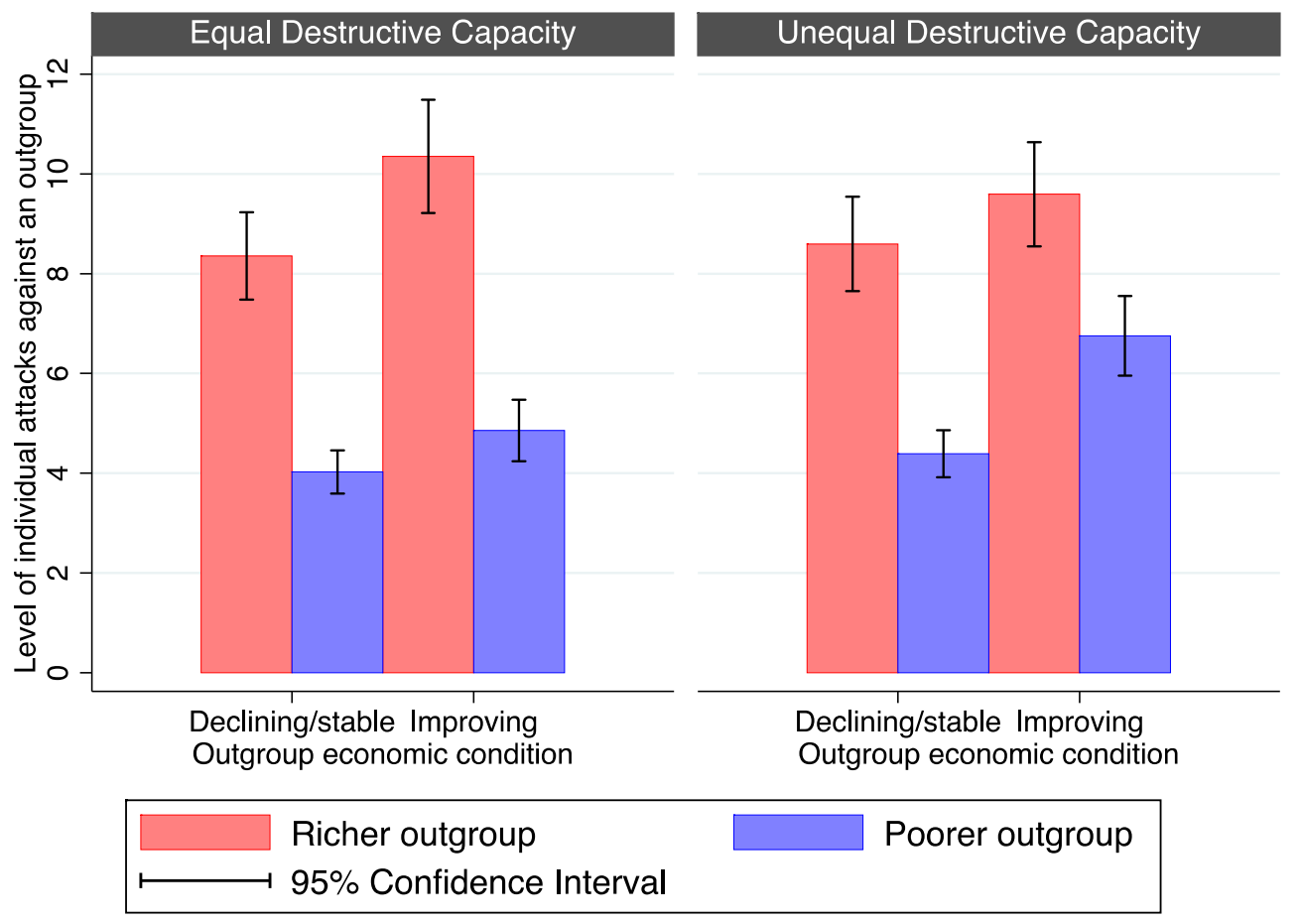




\section{Attacking the weak or the strong?}

\section{Appendix}

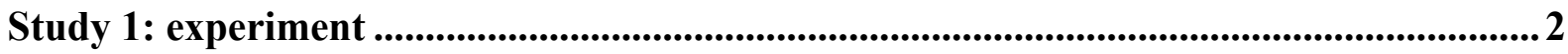

Instructions of the experiment

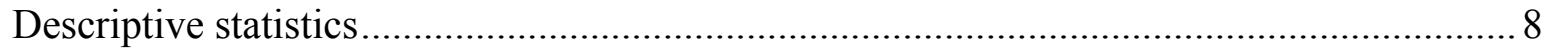

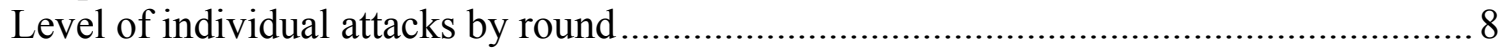

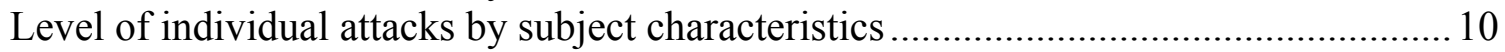

Level of individual attacks against a richer outgroup by subject characteristics ............. 11

Level of individual attacks against a poorer outgroup by subject characteristics ........... 12

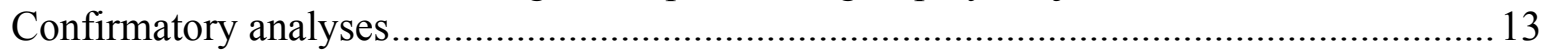

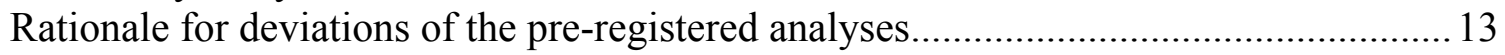

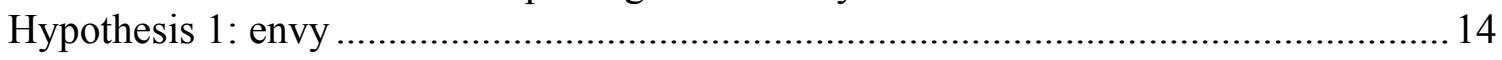

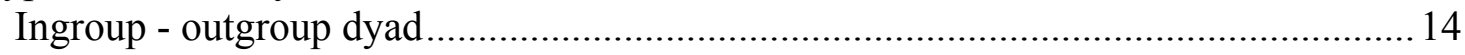

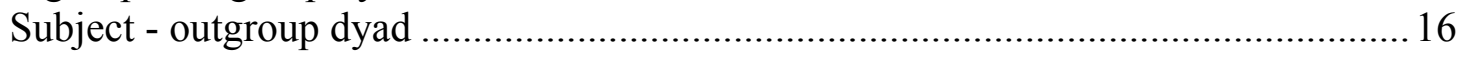

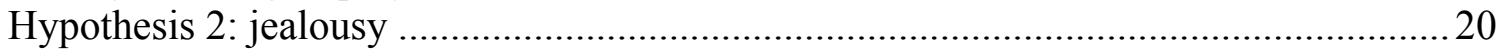

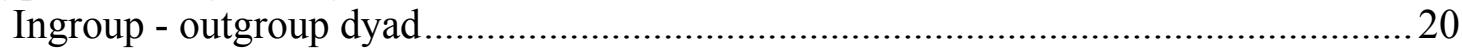

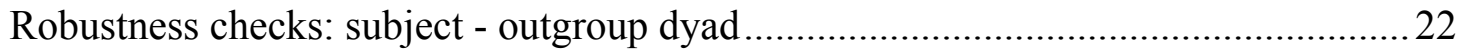

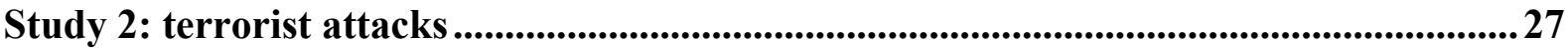

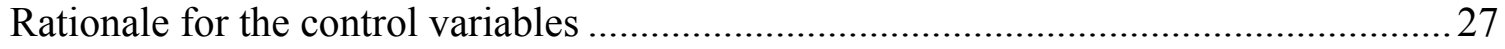

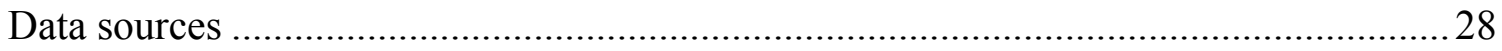

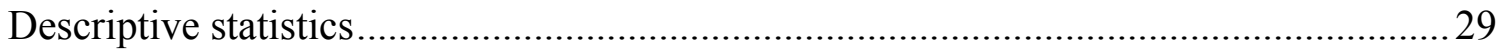




\section{Study 1: experiment}

\section{Instructions of the experiment}

\section{[General instructions]}

Hello and thank you for your participation in our study.

In order to preserve anonymity during the session and when analysing the data, we have assigned you a code. No identifying data will be collected. It will be impossible to link your decisions to your name. The data will only be used for academic research purposes, always respecting anonymity.

Any communication between participants is strictly prohibited, as is any comment on what is appropriate or inappropriate to do during the experiment.

Please turn off your cell phones. We ask you to stay focused on your own computer screen.

During the session, you will have to make simple decisions. Nevertheless, if you face any problem, please do not hesitate to consult us.

During the session, you will have to perform several tasks. Three phases will take place: First, you will participate in a word creation game, then you will engage in an economic group game, and finally you will be asked to fill out a questionnaire.

A new phase will only begin when all participants have finished the previous phase.

We will give you instructions before the beginning of each phase. For everyone's understanding, these instructions will be read aloud.

The duration of this session will not exceed two hours.

You have 10 euros in cash for your participation.

You will find this amount in your personal envelope.

This sum is yours.

In addition to this amount and depending on the choices you make, you can earn more money throughout the games.

You will be informed of your final earnings at the end of the session.

Do you have any questions?

\section{[First task]}

We will now begin the first phase: the word creation game.

(See instructions in Brüggemann, J., Crosetto, P., Meub, L., \& Bizer, K. (2016). Intellectual property rights hinder sequential innovation. Experimental evidence. Research Policy, 45(10), 2054-2068.)

\section{[Inter-group prisoner dilemma]}


You have now completed the word creation game. Therefore, we are going to move on to the economic group game.

In this new game, you will be divided into 5 groups of participants depending on your ranking in number of points during the word creation game:

- The top three players will be in the yellow group.

- The next three in the red group.

- The next three in the purple group.

- The next three in the blue group.

- The last three players in the green group.

You will be part of the same group throughout the game.

In this new game, you have a number of individual points: your personal prize pool. At the beginning of the game, your prize pool contains 10 times the number of points you won during the word-creation game.

The game is composed of 15 successive rounds. In each round you must decide how many points you want to take from other groups to give them to your group.

Taking points from another group has a cost: to take 1.5 points from a group, you must spend 1 point of your personal prize pool. In that case :

- You take 1.5 points from the other group, that is 0.5 points per player from this group.

- You give 1.5 points to your group, that is 0.5 points per player in your group (including you).

[Unequal Destructive Capacity (UDC) treatment]

\{

There is a limit to the number of points you can spend to take points from other groups: you can not spend more than $10 \%$ of your personal prize pool per turn.

\}

[Equal Destructive Capacity (EDC) treatment]

\{

There is a limit to the number of points you can spend to take points from other groups: you can not spend more than 50 points of your personal prize pool per turn.

\}

[Screenshot Decision page 1] 


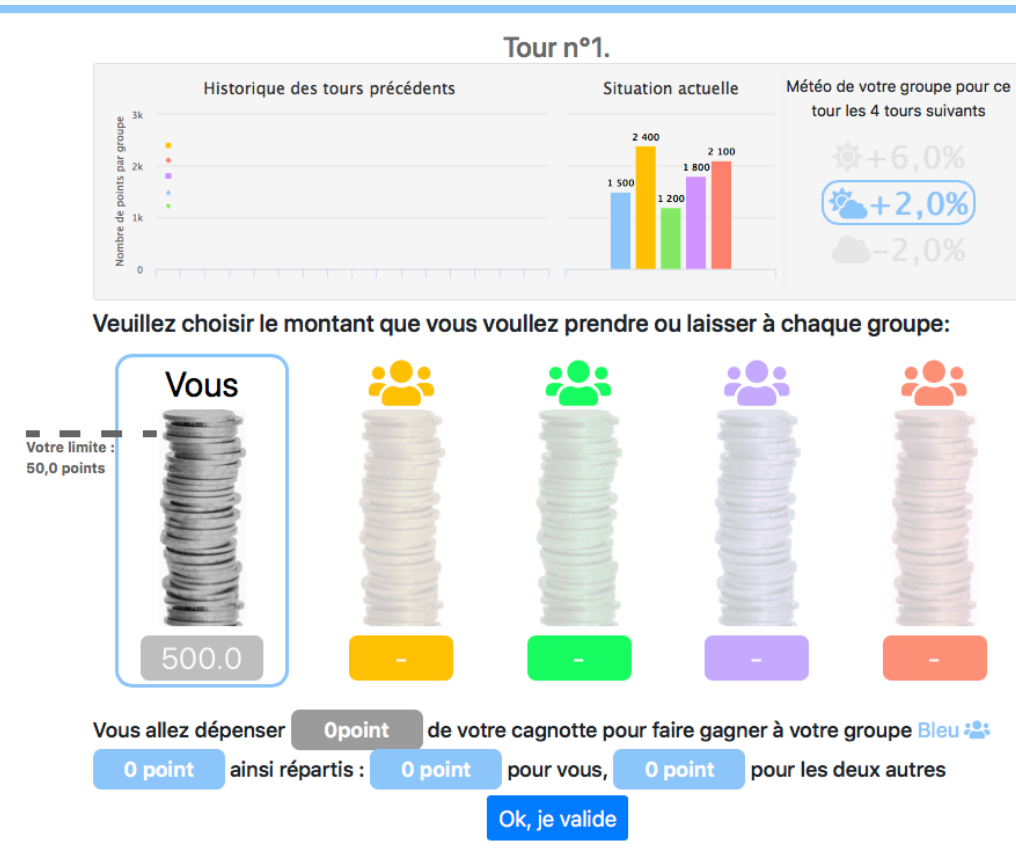

Temps restant pour faire votre choix 1:55

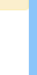




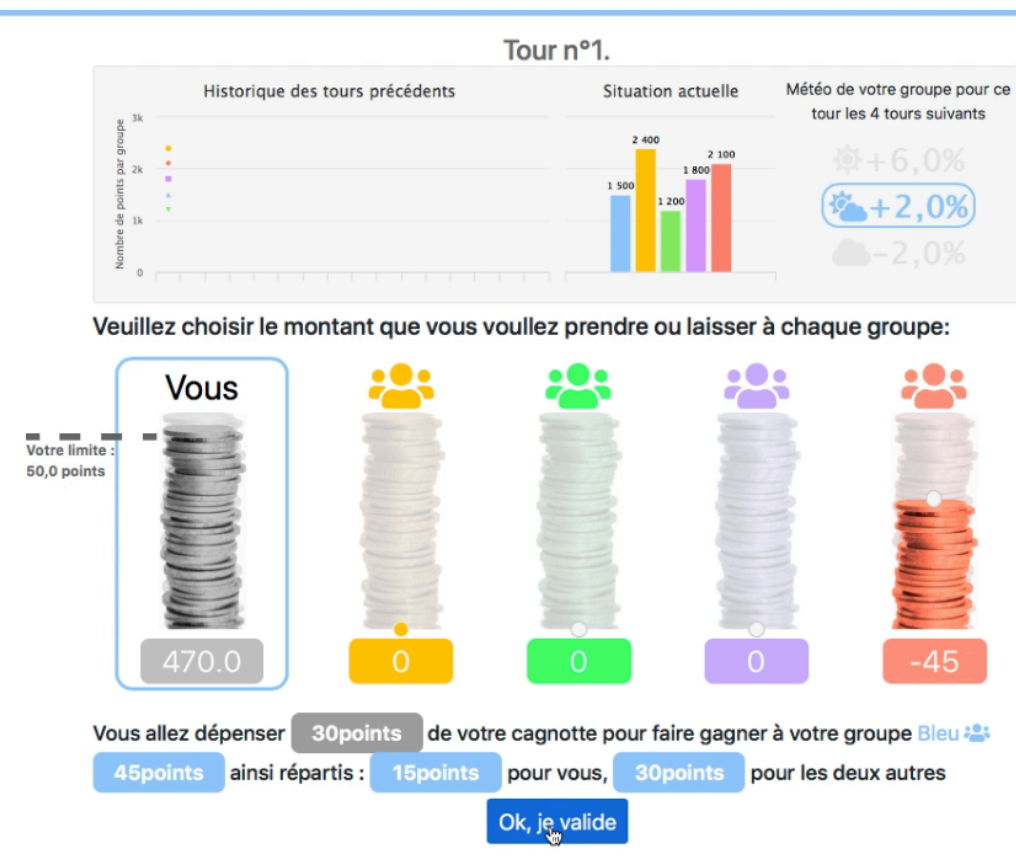

mps restant pour faire votre choix 0:47 


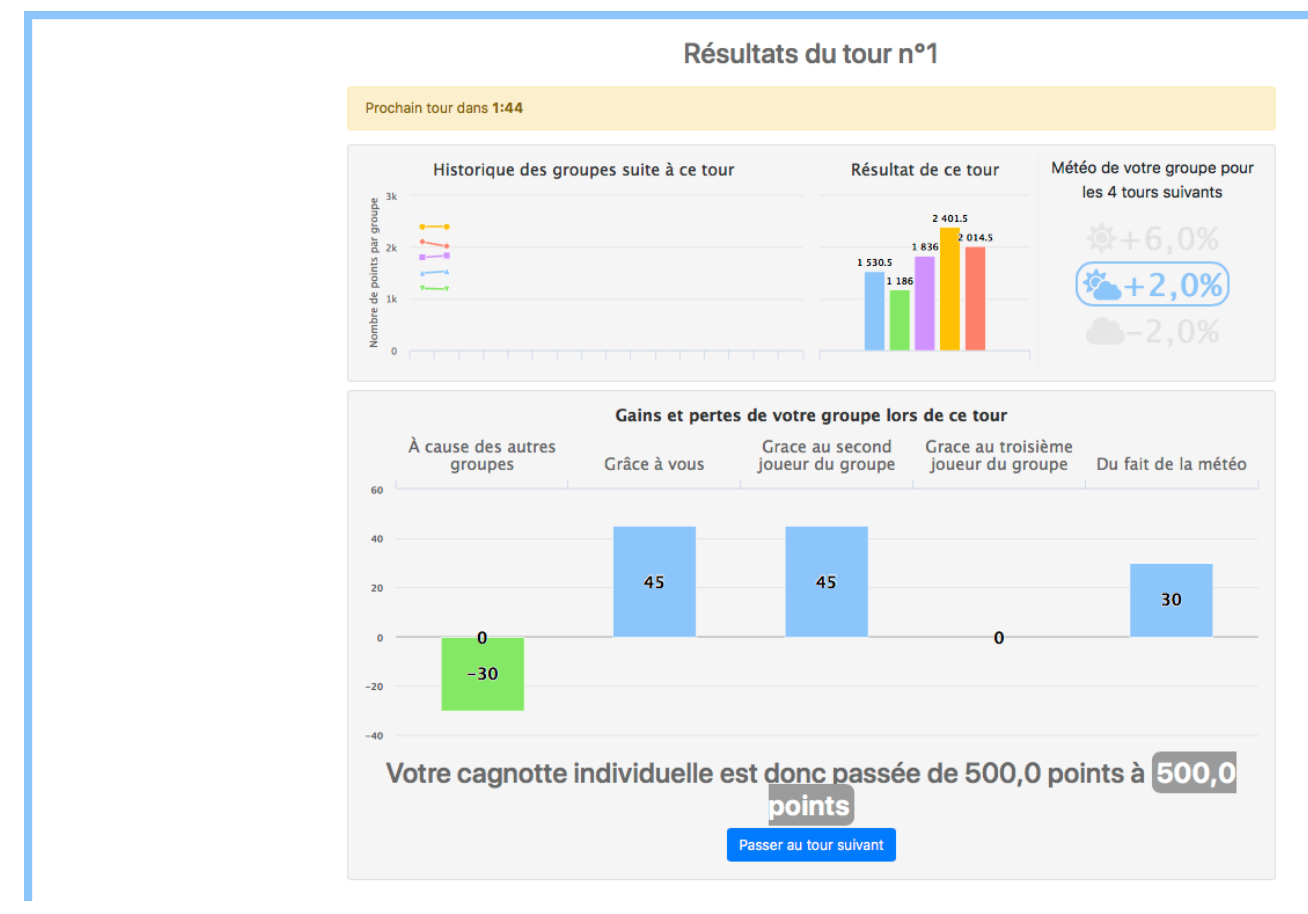

Let's go back to the game screen. After validating your decision and once everyone has played, the results page is displayed.

At the top of the screen, you still see information about the situation of your group and the other groups. This information has been updated based on the results of the tour that has just been played.

In the middle of the screen, you now see a summary of the gains and losses of your group of the round that has just been played. In this example, you see on the left that the green group has taken 30 points from your group overall - that is 10 points per player in your group, including you. As for you, you have given 45 points to your group - 15 points per player - by taking them from the red group. For that purpose, you spent 30 points of your personal prize pool. On the right, you see that another player in your group has also given 45 points to your group by taking them from another group. Then you see that the third player in your group has not brought points to your group by taking to other groups. Finally, on the far right, you see that the weather, which is of $+2 \%$ for your group, has brought 30 points to your group.

Finally, at the end of this round, your personal prize pool after these different calculations is 500 points.

Indeed, you spent 30 points to take points from the red group. You have gained 15 points from this action and 15 points thanks to another player in your group. This compensates. In addition, you lost 10 points because of the green group and gained 10 points because of your weather. This also compensates. Therefore, you still have the same number of points.

At the end of the 15 rounds, you will see the number of points accumulated in your personal prize pool.

Thus, in this new part you put into play your gains of the word creation game.

At the end of the game, the number of points in your personal prize pool will be divided by ten, and this score will determine your final gains in Euros, at the conversion rate of 1 POINT $=0.25 €$. 
This final amount will be added to the 10 Euros in you envelope.

Do you have any questions?

\section{[Questionnaire and end of experience]}

Now that you have completed the economic group game, we will ask you to complete a brief questionnaire.

Once this questionnaire is completed, we will call you to proceed to the payment.

We thank you for participating in this study. 


\section{Descriptive statistics}

\section{Level of individual attacks by round}

Mean level of individual attacks against an outgroup (and SDs) by round

\begin{tabular}{c|cc}
\hline Round & $\begin{array}{c}\text { Level of } \\
\text { individual } \\
\text { attacks }\end{array}$ & $\begin{array}{c}\text { Share of individual } \\
\text { resources } \\
\text { contributed to } \\
\text { attack }\end{array}$ \\
\hline 1 & $7.16(9.71)$ & $0.015(0.02)$ \\
2 & $8.02(10.3)$ & $0.017(0.022)$ \\
3 & $7.74(10.9)$ & $0.017(0.024)$ \\
4 & $7.34(11.1)$ & $0.017(0.026)$ \\
5 & $6.86(10.4)$ & $0.016(0.025)$ \\
6 & $6.83(9.88)$ & $0.018(0.028)$ \\
7 & $6.89(10.5)$ & $0.019(0.038)$ \\
8 & $6.73(10.4)$ & $0.018(0.03)$ \\
9 & $6.51(10.1)$ & $0.019(0.032)$ \\
10 & $5.91(9.83)$ & $0.019(0.036)$ \\
11 & $6.38(10.2)$ & $0.022(0.04)$ \\
12 & $6.08(9.69)$ & $0.022(0.039)$ \\
13 & $5.43(8.8)$ & $0.02(0.037)$ \\
14 & $5.2(8.78)$ & $0.022(0.053)$ \\
15 & $4.56(8.71)$ & $0.021(0.05)$ \\
\hline All & $6.54(10)$ & $0.019(0.034)$
\end{tabular}

Comments: the mean level of individual attacks decreases over the game, but this mainly reflects the fact that individual resources that subject can contribute to attack also decrease over the game. Indeed, the mean share of individual resources contributed to attacks does not decrease over the game. Looking at the boxplots gives a better view. 
Share of individual resources contributed to attack an out-group by round

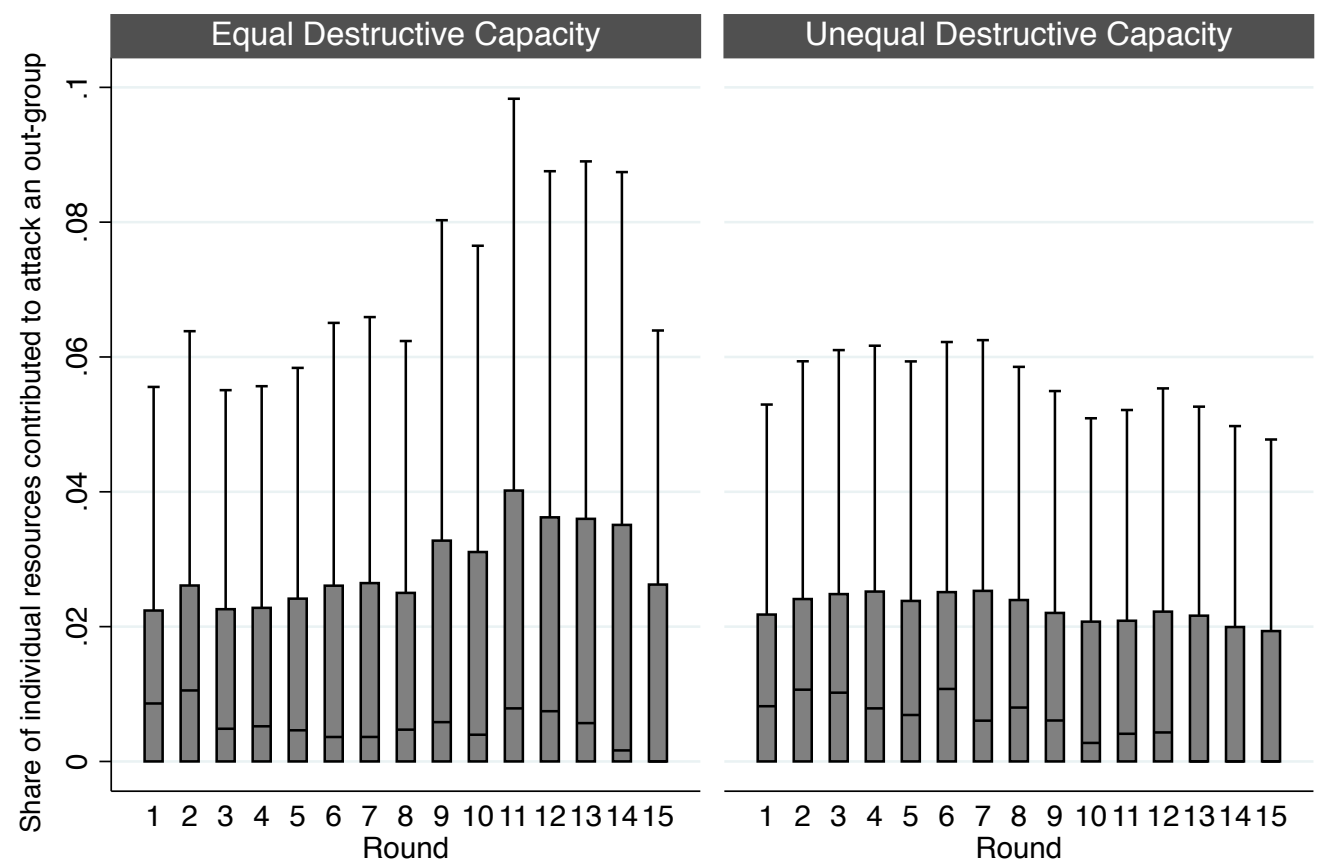

Comments: the share of individual resources contributed to attacks clearly decreases in the Unequal Destructive Capacity (UDC) treatment (both the median and upper quartile). In the Equal Destructive Capacity (EDC) treatment, the median share of resources contributed to attack also decreases but dispersions increases - i.e. high level attacks become more frequent over the game. 


\section{Level of individual attacks by subject characteristics}

Grand-mean of level of individual attacks against an outgroup by individual characteristics, and appropriate bivariate statistical tests ( $\mathrm{p}$-values $<0.05$ in bold)

\begin{tabular}{|c|c|c|}
\hline Subjects characteristics & $\begin{array}{l}\text { Grand-mean } \\
\text { (and SD) }\end{array}$ & Test \\
\hline Gender & & T-test \\
\hline $\begin{array}{l}\text { Female }(\mathrm{N}=177) \\
\text { Male }(\mathrm{N}=123)\end{array}$ & $\begin{array}{l}6.17(2.96) \\
7.1(3.06)\end{array}$ & $t(298)=2.6404, p=0.0087$ \\
\hline Age & & Pearson correlation ${ }^{1}$ \\
\hline $18-20$ years $(\mathrm{N}=111)$ & $6.32(3.05)$ & \\
\hline $21-25$ years $(\mathrm{N}=102)$ & $6.67(3.04)$ & \\
\hline $26-40$ years $(\mathrm{N}=50)$ & $6.58(2.88)$ & $\mathrm{r}(298)=0.0681, \mathrm{p}=0.2393$ \\
\hline$>40$ years $(\mathrm{N}=37)$ & $6.86(3.23)$ & \\
\hline Education & & One-way anova \\
\hline Less than highchool $(\mathrm{N}=56)$ & $6.34(3.08)$ & \\
\hline Highschool $(\mathrm{N}=84)$ & $6.34(2.98)$ & \\
\hline Bachelor $(\mathrm{N}=58)$ & $6.44(2.9)$ & $F(4,295)=2.78, p=0.0269$ \\
\hline Master $(\mathrm{N}=51)$ & $7.79(3.05)$ & \\
\hline Phd $(\mathrm{N}=51)$ & $6(2.98)$ & \\
\hline Working status & & One-way anova \\
\hline Student $(\mathrm{N}=205)$ & $6.52(3.05)$ & \\
\hline Worker $(\mathrm{N}=76)$ & $6.59(2.97)$ & $F(2,297)=0.03, p=0.9749$ \\
\hline No $(\mathrm{N}=19)$ & $6.66(3.29)$ & \\
\hline Percreived self cooperation $^{2}$ & & Pearson correlation ${ }^{1}$ \\
\hline Low $(\mathrm{N}=59)$ & $5.44(2.89)$ & \\
\hline $\operatorname{High}(\mathrm{N}=231)$ & $6.82(3.01)$ & $\mathbf{r}(298)=0.2857, \mathrm{p}<0.0001$ \\
\hline Left-right self position ${ }^{3}$ & & Pearson correlation $^{1}$ \\
\hline Left $(\mathrm{N}=121)$ & $6.77(2.84)$ & \\
\hline Center $(\mathrm{N}=111)$ & $6.05(3.09)$ & $\mathrm{r}(298)=-0.0211, \mathrm{p}=0.7155$ \\
\hline Right $(\mathrm{N}=68)$ & $6.96(3.2)$ & \\
\hline Social Dominance Orientation ${ }^{4}$ & & Pearson correlation ${ }^{1}$ \\
\hline Low $(\mathrm{N}=157)$ & $6.47(2.94)$ & $r(208)=00060 n=00055$ \\
\hline $\operatorname{High}(\mathrm{N}=143)$ & $6.64(3.14)$ & $r(298)=-0.0069, p=0.9055$ \\
\hline All subjects $(N=300)$ & $6.55(3.03)$ & \\
\hline
\end{tabular}

${ }^{1}$ For age, perceived self-cooperation, left-righ self position and social dominance orientation: we used categories to describe the means but treat the variable as linear for the test.

${ }^{2}$ For perceived cooperation: "low" refers to subjects that described themselves as "not very" or "not at all" cooperative and "high" refers to subjects that described themselves as "fairly" or "very" cooperative.

${ }^{3}$ For Left-right self position: "left" refers to subjects that positioned themselves at 1 to 4 , "center" at 5 or 6 , "right" at 7 to 10 on the left-right scale.

${ }^{4}$ For Social Dominance Orientation: "low" refers to subjects that were equal or below the median score on the scale and "high" refers to subject that were above the median score. 


\section{Level of individual attacks against a richer outgroup by subject characteristics}

Grand-mean of level of individual attacks against a richer outgroup by individual characteristics, and appropriate bivariate statistical tests ( $\mathrm{p}$-values $<0.05$ in bold)

\begin{tabular}{|c|c|c|}
\hline Subjects characteristics & $\begin{array}{l}\text { Grand-mean } \\
\text { (and SD) }\end{array}$ & Test \\
\hline Gender & & T-test \\
\hline $\begin{array}{l}\text { Female }(\mathrm{N}=161) \\
\text { Male }(\mathrm{N}=115)\end{array}$ & $\begin{array}{l}7.9(4.72) \\
8.58(5.3)\end{array}$ & $\mathrm{t}(274)=1.1212, \mathrm{p}=0.2632$ \\
\hline Age & & Pearson correlation ${ }^{1}$ \\
\hline $18-20$ years $(\mathrm{N}=102)$ & $7.54(4.38)$ & \\
\hline $21-25$ years $(\mathrm{N}=90)$ & $8.42(5.58)$ & \\
\hline $26-40$ years $(\mathrm{N}=48)$ & $6.58(5.37)$ & $\mathrm{r}(274)=0.0934, \mathrm{p}=0.1215$ \\
\hline$>40$ years $(\mathrm{N}=36)$ & $8.51(4.35)$ & \\
\hline Education & & One-way anova \\
\hline Less than highchool $(\mathrm{N}=56)$ & $7.98(4.71)$ & \\
\hline Highschool $(\mathrm{N}=75)$ & $7.73(4.06)$ & \\
\hline Bachelor $(\mathrm{N}=52)$ & $8.26(5.1)$ & $F(4,271)=0.79, p=0.5305$ \\
\hline Master $(\mathrm{N}=45)$ & $9.32(5.71)$ & \\
\hline Phd $(\mathrm{N}=48)$ & $7.95(5.68)$ & \\
\hline Working status & & One-way anova \\
\hline Student $(\mathrm{N}=186)$ & $7.91(4.95)$ & \\
\hline Worker $(\mathrm{N}=72)$ & $8.35(4.38)$ & $F(2,273)=1.92, p=0.1488$ \\
\hline No $(\mathrm{N}=18)$ & $10.3(6.92)$ & \\
\hline Percreived self cooperation $^{2}$ & & Pearson correlation ${ }^{1}$ \\
\hline Low $(\mathrm{N}=54)$ & $6.97(4.01)$ & $r(274)=01684 \quad n=00050$ \\
\hline High $(N=222)$ & $8.47(5.15)$ & $1(2 / 4)-0.1004, p-0.0000$ \\
\hline Left-right self position ${ }^{3}$ & & Pearson correlation ${ }^{1}$ \\
\hline Left $(N=111)$ & $9.29(5.58)$ & \\
\hline Center (N=102) & $7.17(3.93)$ & $r(274)=-0.1580, p=0.0085$ \\
\hline Right $(\mathrm{N}=63)$ & $7.86(5.03)$ & \\
\hline Social Dominance Orientation ${ }^{4}$ & & Pearson correlation ${ }^{1}$ \\
\hline Low $(\mathrm{N}=145)$ & $8.97(5.31)$ & $\mathbf{r}(274)=-0.1326, p=0.0277$ \\
\hline High $(\mathrm{N}=131)$ & $7.3(4.43)$ & $(2-1) \quad-0.0020, p \quad 0.021)$ \\
\hline All subjects $(N=276)^{5}$ & $8.18(4.97)$ & \\
\hline
\end{tabular}

\footnotetext{
${ }^{1}$ For age, perceived self-cooperation, left-right self position and social dominance orientation: we used categories to describe the means but treat the variable as linear for the test.

${ }^{2}$ For perceived cooperation: "low" refers to subjects that described themselves as "not very" or "not at all" cooperative and "high" refers to subjects that described themselves as "fairly" or "very" cooperative.

${ }^{3}$ For Left-right self position: "left" refers to subjects that positioned themselves at 1 to 4 , "center" at 5 or 6 , "right" at 7 to 10 on the left-right scale.

${ }^{4}$ For Social Dominance Orientation: "low" refers to subjects that were equal or below the median score on the scale and "high" refers to subject that were above the median score.

${ }^{5}$ The number of subjects is not 300 because some (24) subjects did not face richer outgroups during the game (they were part of the richest group all along the game).
} 


\section{Level of individual attacks against a poorer outgroup by subject characteristics}

Grand-mean of level of individual attacks against a poorer outgroup by individual characteristics, and appropriate bivariate statistical tests ( $\mathrm{p}$-values $<0.05$ in bold)

\begin{tabular}{|c|c|c|}
\hline Subjects characteristics & $\begin{array}{l}\text { Grand-mean } \\
\text { (and SD) }\end{array}$ & Test \\
\hline Gender & & T-test \\
\hline Female $(\mathrm{N}=158)$ & $5.12(3.18)$ & $\mathrm{t}(265)=2.6269, p=0.0091$ \\
\hline Male $(\mathrm{N}=109)$ & $6.31(4.21)$ & \\
\hline Age & & Pearson correlation ${ }^{1}$ \\
\hline $18-20$ years $(\mathrm{N}=98)$ & $5.82(4.28)$ & \\
\hline $21-25$ years $(\mathrm{N}=96)$ & $5.52(3.21)$ & \\
\hline $26-40$ years $(\mathrm{N}=43)$ & $5.23(3.33)$ & $\mathrm{r}(265)=-0.0321, \mathrm{p}=0.6021$ \\
\hline$>40$ years $(\mathrm{N}=30)$ & $5.69(5.69)$ & \\
\hline Education & & One-way anova \\
\hline Less than highchool $(\mathrm{N}=45)$ & $5.46(3.09)$ & \\
\hline Highschool $(\mathrm{N}=74)$ & $5.81(4.29)$ & \\
\hline Bachelor $(\mathrm{N}=56)$ & $4.97(3.5)$ & $F(4,262)=1.30, p=0.2701$ \\
\hline Master $(\mathrm{N}=49)$ & $6.48(3.47)$ & \\
\hline Phd $(\mathrm{N}=43)$ & $5.23(3.48)$ & \\
\hline Working status & & One-way anova \\
\hline Student $(\mathrm{N}=186)$ & $5.78(3.82)$ & \\
\hline Worker $(\mathrm{N}=64)$ & $5.29(3.43)$ & $F(2,264)=0.83, p=0.4368$ \\
\hline No $(\mathrm{N}=17)$ & $4.83(2.88)$ & \\
\hline Percreived self cooperation $^{2}$ & & Pearson correlation ${ }^{1}$ \\
\hline Low $(\mathrm{N}=49)$ & $4.66(3.27)$ & $\mathrm{r}(265)=0.2487, \mathrm{p}<0.0001$ \\
\hline High $(\mathrm{N}=218)$ & $5.82(3.73)$ & \\
\hline Left-right self position ${ }^{3}$ & & Pearson correlation ${ }^{1}$ \\
\hline Left $(\mathrm{N}=110)$ & $5.45(3.76)$ & \\
\hline Center $(\mathrm{N}=97)$ & $5.26(3.3)$ & $\mathrm{r}(265)=0.0850, \mathrm{p}=0.1659$ \\
\hline Right $(\mathrm{N}=60)$ & $6.44(4)$ & \\
\hline Social Dominance Orientation ${ }^{4}$ & & Pearson correlation ${ }^{1}$ \\
\hline Low $(\mathrm{N}=143)$ & $5.1(3.12)$ & $\mathrm{r}(265)=0.0600, \mathrm{p}=0.3290$ \\
\hline $\operatorname{High}(\mathrm{N}=124)$ & $6.19(4.17)$ & \\
\hline All subjects $(N=267)^{5}$ & $5.6(3.67)$ & \\
\hline
\end{tabular}

${ }^{1}$ For age, perceived self-cooperation, left-right self position and social dominance orientation: we used categories to describe the means but treat the variable as linear for the test.

${ }^{2}$ For perceived cooperation: "low" refers to subjects that described themselves as "not very" or "not at all" cooperative and "high" refers to subjects that described themselves as "fairly" or "very" cooperative.

${ }^{3}$ For Left-right self position: "left" refers to subjects that positioned themselves at 1 to 4 , "center" at 5 or 6 , "right" at 7 to 10 on the left-right scale.

${ }^{4}$ For Social Dominance Orientation: "low" refers to subjects that were equal or below the median score on the scale and "high" refers to subject that were above the median score.

${ }^{5}$ The number of subjects is not 300 because some (33) subjects did not face richer outgroups during the game (they were part of the richest group all along the game). 


\section{Confirmatory analyses}

This section presents robustness checks for the confirmatory analyses relative to the test of the hypotheses detailed in the paper. In the main text, we presented results from multilevel regression models based on subject-outgroup dyads, explaining the individual level of attacks against an outgroup. We here present robustness checks based on alternative models for each hypothesis:

- Multilevel regression models based on ingroup-outgroup dyads.

- Regression models based on subject-outgroup dyads with subject fixed effects.

- Zero-inflated regression models based on subject-outgroup dyads, with standard errors clustered on subjects.

\section{Rationale for deviations of the pre-registered analyses}

We pre-registered regression models to test our hypotheses before data collection on OSF: http://osf.io/neaqu Note that the present paper focuses on hypotheses 2 (Situation of the outgroup) and 3 (Relative situation of the in-group compared to the out-group) of the preregistered project. Hypothesis 1 (Situation of the in-group) is explored in a separate study. The models presented here and in the main text deviate from the pre-registered models in several way:

- First, we chose to estimate negative binomial regressions models instead of linear regressions because our dependent variable (the level of attacks against an outgroup)

- Second, based on the reviewers' suggestion, we chose models in order account for the panel structure of the data (repeated measures of the same subjects for 15 rounds). In the main text, we present results from multilevel regression models with random effects computed at the subject level. Here, we present similar models with random effects computed at the ingroup levels and, alternatively, models with subject fixed effects (i.e. that control for the mean level of attack of each subjects).

- Third, based on the reviewers' suggestion, we control for the "menu" of outgroups available to attack by including the ingroup rank when analyzing the effect of the outgroup being richer. Indeed, depending on their ingroup rank, subjects have a different number of richer/poorer groups available to attack in the game. 


\section{Hypothesis 1: envy}

\section{Ingroup - outgroup dyad}

We estimated a range of multilevel negative binomial models, following this general equation:

$$
\ln a_{i b t}=\beta_{0}+u_{i}+\beta_{1} I_{i b t}+\beta_{2} X_{i b t}+\varepsilon_{i b t}
$$

Where: $a_{i b t}$ is the number of points contributed in attacks by the subject $i$ against the outgroup $b$ at round $t . \beta_{0}$ is the intercept and $u_{i}$ is the subject random effect. $I$ and $X$ are respectively the sets of independent variables of interest and controls. $\varepsilon_{i b t}$ is the error term.

\begin{tabular}{|c|c|c|c|c|}
\hline VARIABLES & I & II & III & IV \\
\hline Outgroup resources & $\begin{array}{c}0.353 * * * \\
(0.0178)\end{array}$ & $\begin{array}{c}0.373 * * * \\
(0.0280)\end{array}$ & $\begin{array}{c}0.350 * * * \\
(0.0181)\end{array}$ & $\begin{array}{c}0.372 * * * \\
(0.0286)\end{array}$ \\
\hline Outgroup resources Squared & & & $\begin{array}{l}0.0237^{*} \\
(0.0118)\end{array}$ & $\begin{array}{l}0.0497 * * \\
(0.0189)\end{array}$ \\
\hline UDC treatment & & $\begin{array}{l}-0.237^{*} \\
(0.109)\end{array}$ & & $\begin{array}{l}-0.190+ \\
(0.110)\end{array}$ \\
\hline UDC treatment $\times$ Outgroup resources & & $\begin{array}{l}-0.0174 \\
(0.0354)\end{array}$ & & $\begin{array}{l}-0.0157 \\
(0.0359)\end{array}$ \\
\hline UDC treatment $\times$ Outgroup resources Squared & & & & $\begin{array}{l}-0.0558^{*} \\
(0.0242)\end{array}$ \\
\hline Ingroup resources & $\begin{array}{l}0.0482+ \\
(0.0264)\end{array}$ & $\begin{array}{c}-0.135^{* * *} \\
(0.0358)\end{array}$ & $\begin{array}{l}0.0488+ \\
(0.0264)\end{array}$ & $\begin{array}{c}-0.130 * * * \\
(0.0359)\end{array}$ \\
\hline UDC treatment $\times$ Ingroup resources & & $\begin{array}{c}0.444 * * * \\
(0.0525)\end{array}$ & & $\begin{array}{c}0.440 * * * \\
(0.0525)\end{array}$ \\
\hline Attacks by the outgroup against the ingroup at $t-1$ & $\begin{array}{c}0.285 * * * \\
(0.0158)\end{array}$ & $\begin{array}{c}0.276 * * * \\
(0.0158)\end{array}$ & $\begin{array}{c}0.287 * * * \\
(0.0159)\end{array}$ & $\begin{array}{l}0.277 * * * \\
(0.0158)\end{array}$ \\
\hline Constant & $\begin{array}{c}2.756 * * * \\
(0.0597)\end{array}$ & $\begin{array}{c}2.851 * * * \\
(0.0768)\end{array}$ & $\begin{array}{c}2.733 * * * \\
(0.0610)\end{array}$ & $\begin{array}{c}2.810 * * * \\
(0.0778)\end{array}$ \\
\hline $\ln ($ alpha $)$ & $\begin{array}{l}-0.00401 \\
(0.0218)\end{array}$ & $\begin{array}{l}-0.0181 \\
(0.0218)\end{array}$ & $\begin{array}{l}-0.00486 \\
(0.0218)\end{array}$ & $\begin{array}{l}-0.0196 \\
(0.0219)\end{array}$ \\
\hline var(Ingroups) & $\begin{array}{c}0.337 * * * \\
(0.0523)\end{array}$ & $\begin{array}{c}0.274 * * * \\
(0.0429)\end{array}$ & $\begin{array}{c}0.340 * * * \\
(0.0528)\end{array}$ & $\begin{array}{c}0.271 * * * \\
(0.0425)\end{array}$ \\
\hline $\begin{array}{l}\text { Observations } \\
\text { Number of Ingroups }\end{array}$ & $\begin{array}{c}5,520 \\
100\end{array}$ & $\begin{array}{c}5,520 \\
100\end{array}$ & $\begin{array}{c}5,520 \\
100\end{array}$ & $\begin{array}{c}5,520 \\
100\end{array}$ \\
\hline
\end{tabular}

Observations are ingroup - outgroup dyads for each round of the game (excluding the first round). Rounds in which at least one group "died" were excluded.

\section{Comments:}

Model I tests the effect of the outgroup resources on the level of ingroup attacks. Model II tests the interaction between the UDC treatment and the effect of the outgroup resources. As expected, model I shows a positive effect of the outgroup resources on the level of ingroup attacks. Contrary to the expected negative interaction, model II shows no significant interaction between this effect and the UDC treatment.

In model III, we test for a quadratic effect of the outgroup resources and in model IV for the interaction between a quadratic effect and the UDC treatment. As illustrated by the following marginal effects, model IV shows that the effect of the outgroup resources on the level of ingroup attacks is exponential in the EDC treatment, while it is not exponential in the UDC treatment. 
Marginal effect of the outgroup resources (with 95\% CI)

Linear effect - computed from the latter negative binomial regressions (model II)

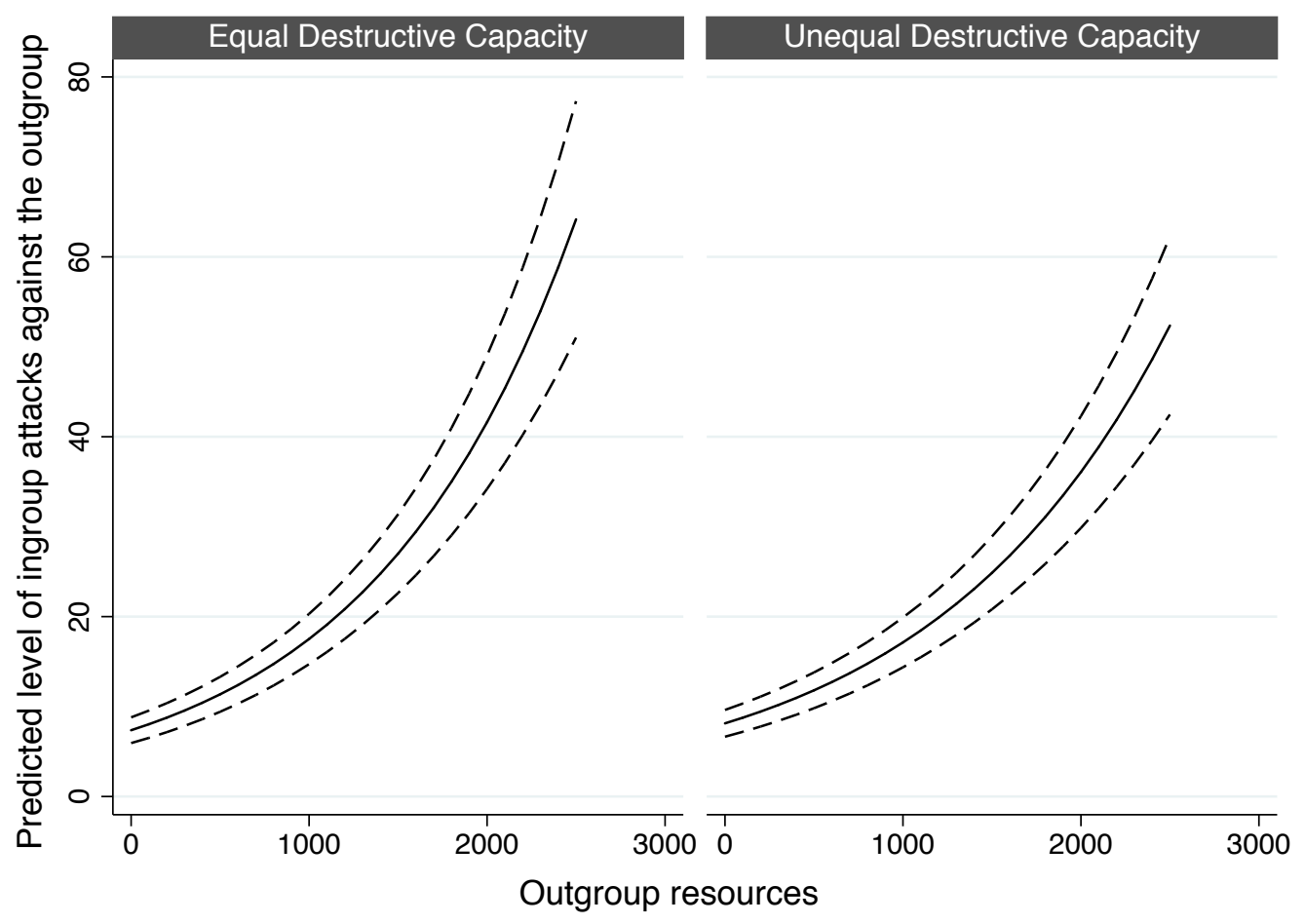

Quadratic effect - computed from the latter negative binomial regressions (model IV)

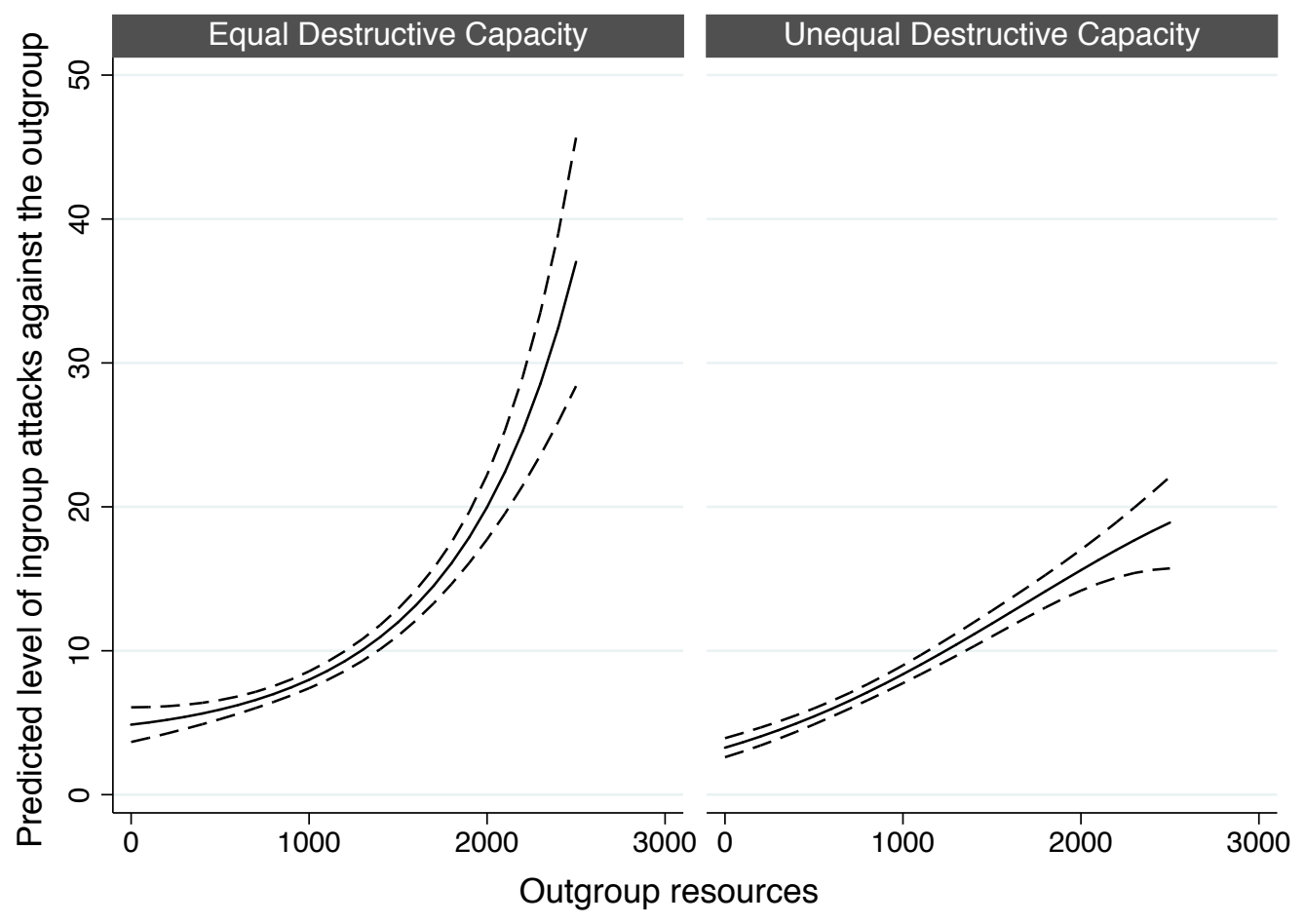




\section{Subject - outgroup dyad}

Fixed effects negative binomial regression models

Standardized coefficients from fixed effects negative binomial regression analyses of the individual level of attacks against an outgroup

\begin{tabular}{|c|c|c|c|c|}
\hline \multirow[b]{2}{*}{ VARIABLES } & I & II & III & IV \\
\hline & \multicolumn{4}{|c|}{ Fixed effects negative binomial } \\
\hline Outgroup resources & $\begin{array}{c}0.337 * * * \\
(0.0113)\end{array}$ & $\begin{array}{c}0.376^{* * * *} \\
(0.0184)\end{array}$ & $\begin{array}{c}0.348 * * * \\
(0.0124)\end{array}$ & $\begin{array}{c}0.369 * * * \\
(0.0188)\end{array}$ \\
\hline Outgroup resources Squared & & & $\begin{array}{l}-0.0190^{*} \\
(0.00813)\end{array}$ & $\begin{array}{c}0.0194 \\
(0.0137)\end{array}$ \\
\hline UDC treatment & & $-{ }^{a}$ & & $-{ }^{\mathrm{a}}$ \\
\hline UDC treatment $\mathrm{x}$ Outgroup resources & & $\begin{array}{l}-0.0485^{*} \\
(0.0234)\end{array}$ & & $\begin{array}{l}-0.00875 \\
(0.0252)\end{array}$ \\
\hline UDC treatment x Outgroup resources Squared & & & & $\begin{array}{c}-0.0660 * * * \\
(0.0172)\end{array}$ \\
\hline Subject resources & $\begin{array}{c}-0.0461 * * * \\
(0.0136)\end{array}$ & $\begin{array}{c}-0.159 * * * \\
(0.0206)\end{array}$ & $\begin{array}{c}-0.0485^{* * *} \\
(0.0136)\end{array}$ & $\begin{array}{c}-0.156 * * * \\
(0.0207)\end{array}$ \\
\hline UDC treatment $x$ Subject resources & & $\begin{array}{c}0.203 * * * \\
(0.0276)\end{array}$ & & $\begin{array}{c}0.199 * * * \\
(0.0277)\end{array}$ \\
\hline Attacks by the outgroup against the ingroup at $t-1$ & $\begin{array}{l}0.176 * * * \\
(0.00897)\end{array}$ & $\begin{array}{l}0.176^{* * *} \\
(0.00912)\end{array}$ & $\begin{array}{l}0.176 * * * \\
(0.00899)\end{array}$ & $\begin{array}{l}0.177 * * * \\
(0.00918)\end{array}$ \\
\hline Constant & $\begin{array}{c}-1.117 * * * \\
(0.0146)\end{array}$ & $\begin{array}{c}-1.159 * * * \\
(0.0208)\end{array}$ & $\begin{array}{c}-1.100 * * * \\
(0.0162)\end{array}$ & $\begin{array}{c}-1.174 * * * \\
(0.0234)\end{array}$ \\
\hline Observations & 16,372 & 16,372 & 16,372 & 16,372 \\
\hline Number of subjects ${ }^{b}$ & 299 & 299 & 299 & 299 \\
\hline
\end{tabular}

Standard errors in parentheses

$* * * \mathrm{p}<0.001, * * \mathrm{p}<0.01, * \mathrm{p}<0.05,+\mathrm{p}<0.1$

Observations are all subject - outgroup dyads for each round of the game (excluding the first round and one subject - see ${ }^{b}$ ). Rounds in which at least one group "died" were excluded.

${ }^{a}$ The UDC treatment variable was included in the model, but because it is perfectly collinear with subject fixed effects, the coefficients was omitted from the table.

${ }^{b}$ One subject was automatically omitted from the analyses because his level of attacks was 0 against all outgroups in all rounds, and hence was perfectly predicted by the subject fixed effect.

\section{Comments:}

We test the same models than the previous table based on subject - outgroup dyads, including subject fixed effects. As shown by the following marginal effects, the results are essentially unchanged. 
Marginal effect of the outgroup resources (with 95\% CI)

Linear effect - computed from the latter fixed effects negative binomial regressions (model II)

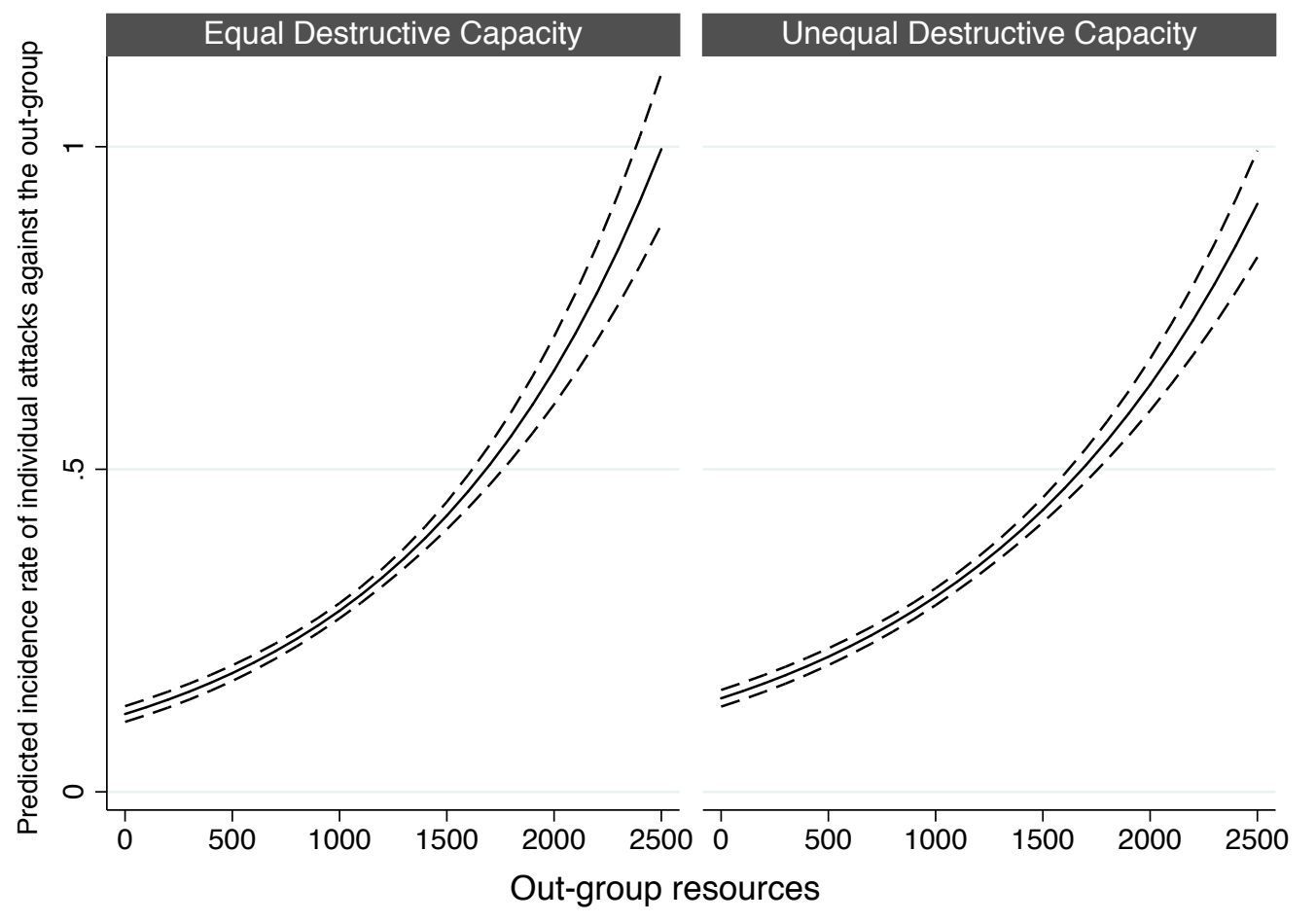

Quadratic effect - computed from the latter fixed effects negative binomial regressions (model IV)

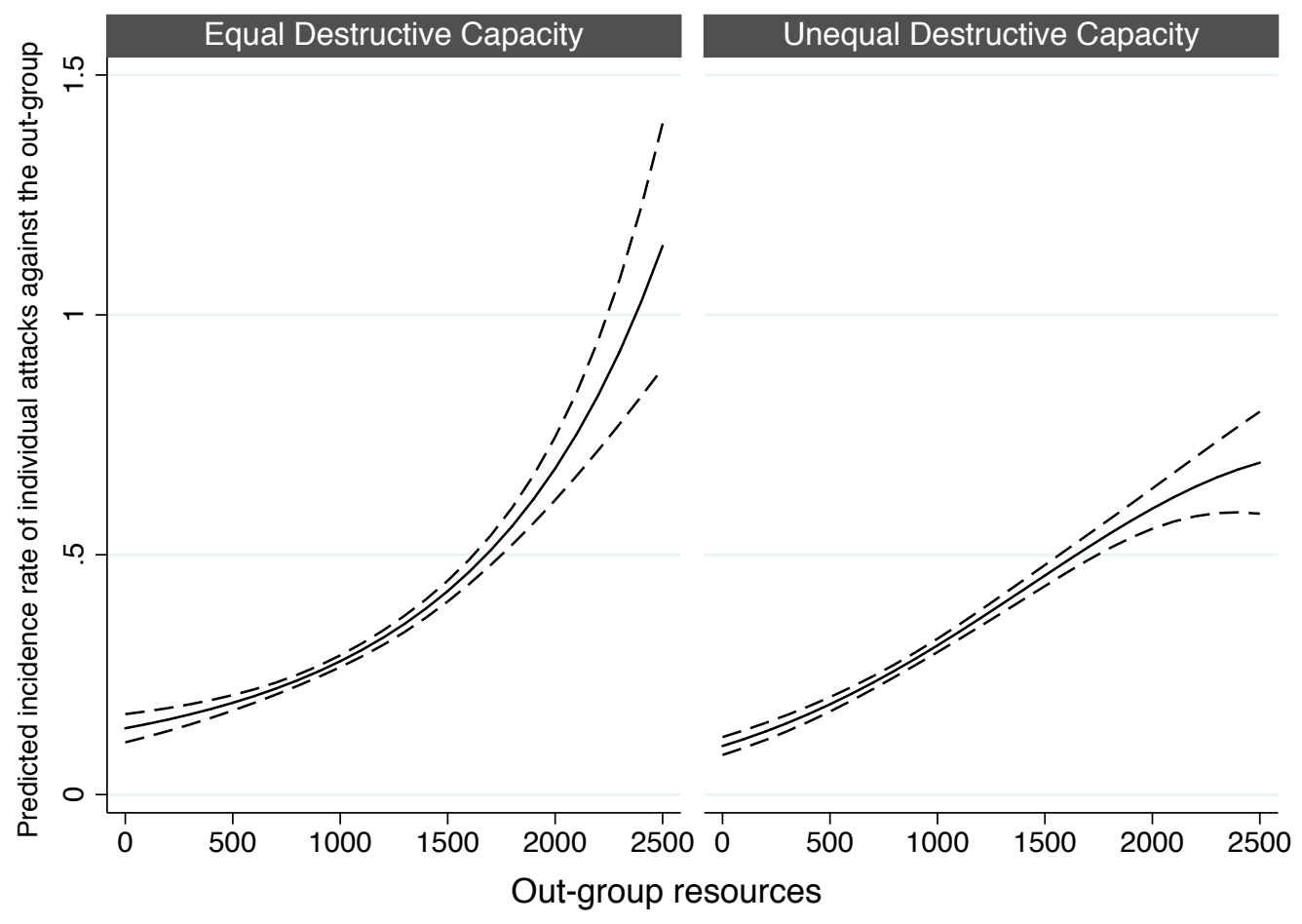


Standardized coefficients from zero-inflate negative binomial regression analyses of the individual level of attacks against an outgroup

\begin{tabular}{|c|c|c|c|c|c|c|c|c|}
\hline \multirow[b]{2}{*}{ VARIABLES } & \multicolumn{2}{|c|}{ I } & \multicolumn{2}{|c|}{ II } & \multicolumn{2}{|c|}{ III } & \multicolumn{2}{|c|}{ IV } \\
\hline & $\begin{array}{l}\text { Level of } \\
\text { attack }\end{array}$ & $\begin{array}{c}\text { Inflate: } \\
\text { absence of } \\
\text { attack }\end{array}$ & $\begin{array}{l}\text { Level of } \\
\text { attack }\end{array}$ & $\begin{array}{c}\text { Inflate: } \\
\text { absence of } \\
\text { attack } \\
\end{array}$ & $\begin{array}{c}\text { Level of } \\
\text { attack }\end{array}$ & $\begin{array}{c}\text { Inflate: } \\
\text { absence of } \\
\text { attack }\end{array}$ & $\begin{array}{c}\text { Level of } \\
\text { attack }\end{array}$ & $\begin{array}{c}\text { Inflate: } \\
\text { absence of } \\
\text { attack }\end{array}$ \\
\hline Outgroup resources & $\begin{array}{c}0.0742 * * \\
(0.0245)\end{array}$ & $\begin{array}{c}-0.381 * * * \\
(0.0455)\end{array}$ & $\begin{array}{c}0.101^{*} \\
(0.0447)\end{array}$ & $\begin{array}{c}-0.463 * * * \\
(0.0705)\end{array}$ & $\begin{array}{l}0.0623 * \\
(0.0285)\end{array}$ & $\begin{array}{c}-0.382 * * * \\
(0.0453)\end{array}$ & $\begin{array}{c}0.0877+ \\
(0.0458)\end{array}$ & $\begin{array}{c}-0.466 * * * \\
(0.0707)\end{array}$ \\
\hline Outgroup resources Squared & & & & & $\begin{array}{c}0.0280 \\
(0.0180)\end{array}$ & $\begin{array}{c}0.0116 \\
(0.0274)\end{array}$ & $\begin{array}{l}0.0655^{*} \\
(0.0303)\end{array}$ & $\begin{array}{c}-0.0331 \\
(0.0360)\end{array}$ \\
\hline UDC treatment & & & $\begin{array}{c}-0.246 * * * \\
(0.0586)\end{array}$ & $\begin{array}{r}-0.0635 \\
(0.123)\end{array}$ & & & $\begin{array}{c}-0.188 * * \\
(0.0600)\end{array}$ & $\begin{array}{l}-0.126 \\
(0.130)\end{array}$ \\
\hline UDC treatment $\mathrm{x}$ Outgroup resources & & & $\begin{array}{c}0.0134 \\
(0.0528)\end{array}$ & $\begin{array}{c}0.106 \\
(0.0906)\end{array}$ & & & $\begin{array}{c}0.0284 \\
(0.0563)\end{array}$ & $\begin{array}{c}0.104 \\
(0.0905)\end{array}$ \\
\hline UDC treatment $x$ Outgroup resources Squared & & & & & & & $\begin{array}{c}-0.0688^{*} \\
(0.0344)\end{array}$ & $\begin{array}{c}0.0744 \\
(0.0508)\end{array}$ \\
\hline Subject resources & $\begin{array}{c}0.109 * * * \\
(0.0299)\end{array}$ & $\begin{array}{c}0.0759 \\
(0.0683)\end{array}$ & $\begin{array}{c}-0.0282 \\
(0.0459)\end{array}$ & $\begin{array}{l}0.263 * * \\
(0.0851)\end{array}$ & $\begin{array}{l}0.109 * * * \\
(0.0300)\end{array}$ & $\begin{array}{c}0.0751 \\
(0.0680)\end{array}$ & $\begin{array}{c}-0.0248 \\
(0.0457)\end{array}$ & $\begin{array}{l}0.260 * * \\
(0.0853)\end{array}$ \\
\hline UDC treatment $x$ Subject resources & & & $\begin{array}{c}0.310 * * * \\
(0.0606)\end{array}$ & $\begin{array}{c}-0.308^{*} \\
(0.133)\end{array}$ & & & $\begin{array}{c}0.305 * * * \\
(0.0605)\end{array}$ & $\begin{array}{c}-0.308^{*} \\
(0.132)\end{array}$ \\
\hline Attacks by the outgroup against the ingroup at $t-1$ & $\begin{array}{c}0.217 * * * \\
(0.0142)\end{array}$ & $\begin{array}{c}-0.267 * * * \\
(0.0320)\end{array}$ & $\begin{array}{l}0.204 * * * \\
(0.0143)\end{array}$ & $\begin{array}{c}-0.265 * * * \\
(0.0313)\end{array}$ & $\begin{array}{c}0.220 * * * \\
(0.0140)\end{array}$ & $\begin{array}{c}-0.265^{* * *} \\
(0.0321)\end{array}$ & $\begin{array}{l}0.206^{* * *} \\
(0.0138)\end{array}$ & $\begin{array}{c}-0.263 * * * \\
(0.0315)\end{array}$ \\
\hline Constant & $\begin{array}{c}2.344 * * * \\
(0.0311)\end{array}$ & $\begin{array}{c}-0.343 * * * \\
(0.0604)\end{array}$ & $\begin{array}{c}2.436 * * * \\
(0.0427)\end{array}$ & $\begin{array}{c}-0.301 * * * \\
(0.0854)\end{array}$ & $\begin{array}{c}2.319 * * * \\
(0.0326)\end{array}$ & $\begin{array}{c}-0.353 * * * \\
(0.0652)\end{array}$ & $\begin{array}{c}2.382 * * * \\
(0.0439)\end{array}$ & $\begin{array}{c}-0.277 * * \\
(0.0901)\end{array}$ \\
\hline Observations & & 28 & & & & 28 & & 28 \\
\hline
\end{tabular}

Robust standard errors in parentheses. Standard errors are clustered by subject.

$* * * \mathrm{p}<0.001, * * \mathrm{p}<0.01, * \mathrm{p}<0.05,+\mathrm{p}<0.1$

Observations are all subject - outgroup dyads for each round of the game (excluding the first round). Rounds in which at least one group "died" were excluded.

\section{Comments:}

We test the same models than the previous table but based on a zero-inflated negative binomial regression - which separately predicts the absence of individual attack (by a logistic model) and, if an attack occurred, the level of attacks (by a count model). For each model, the first row shows the effects of the predictors on the level of attack (non-zero count negative binomial), and the second row shows the effects of the predictors on the probability of no attack (certain zeros logit).

As shown by the following marginal effects, the results are essentially unchanged. Interestingly, the level of outgroup resources generally both significantly decreases the probability of no attack and increases the level of attack. Yet, the quadratic effect of the outgroup resources only affects the level of attacks: this means that outgroups with high resources are not more likely to receive an attack in the EDC treatment, but that the mean level of such attack is significantly higher. 
Marginal effect of the outgroup resources (with 95\% CI)

Linear effect - computed from the latter zero-inflated negative binomial regressions (model II)

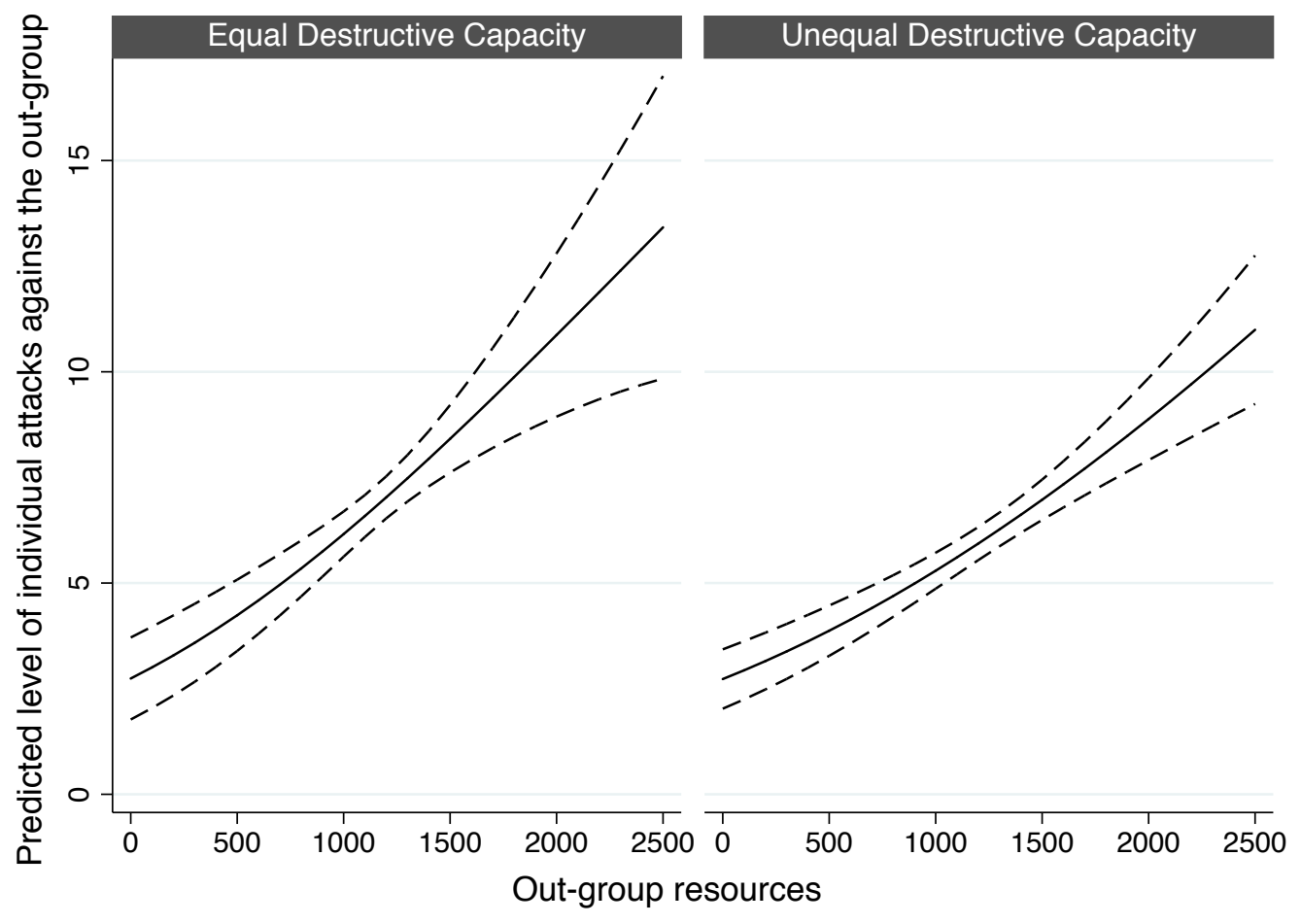

Quadratic effect - computed from the latter zero-inflated negative binomial regressions (model IV)

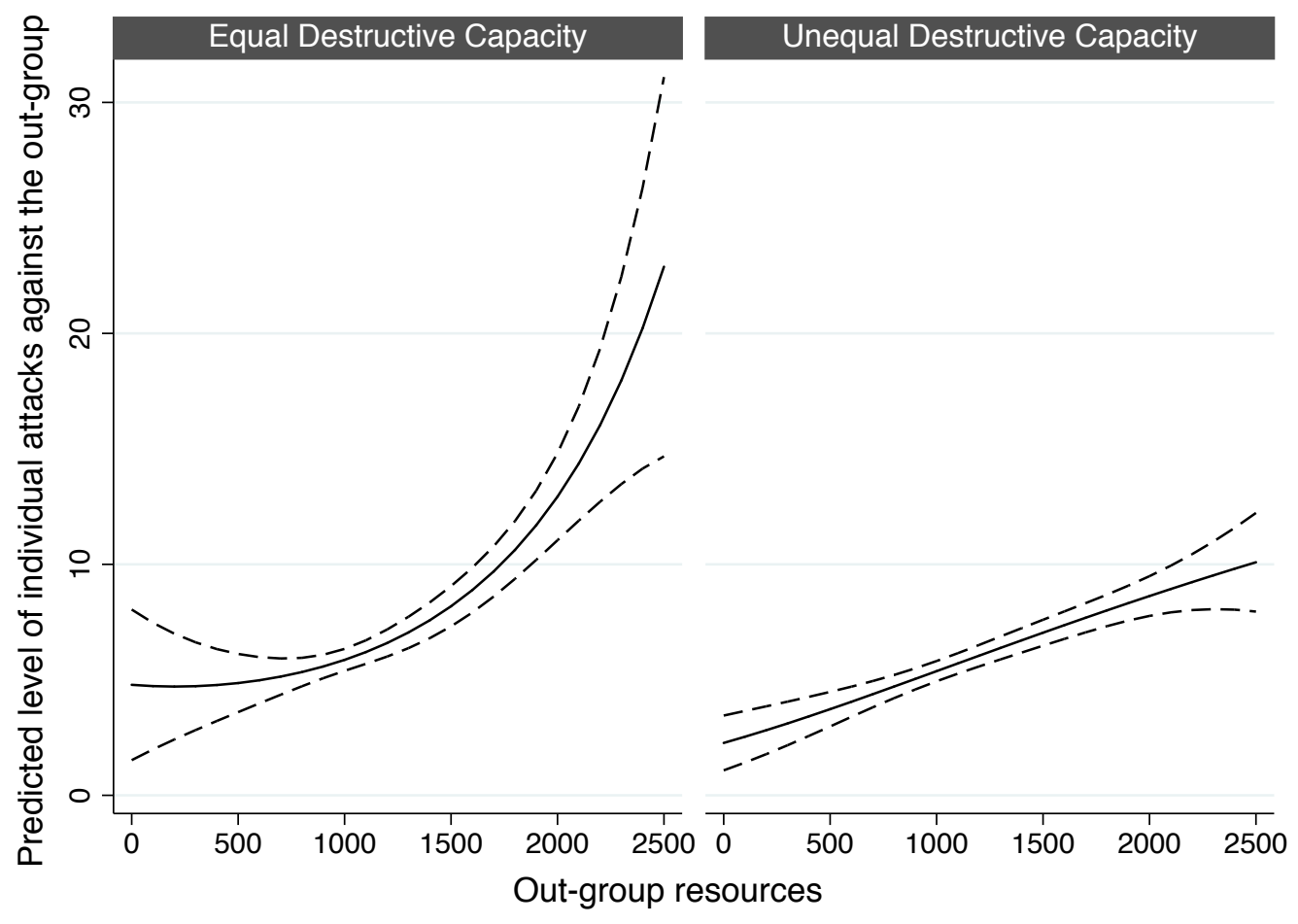




\section{Hypothesis 2: jealousy}

\section{Ingroup - outgroup dyad}

We estimated a range of multilevel negative binomial models, following the same general equation than presented before in the Hypothesis 1 section.

\begin{tabular}{|c|c|c|c|c|c|}
\hline VARIABLES & I & II & III & $\begin{array}{c}\text { IV } \\
\text { Richer } \\
\text { outgroup }\end{array}$ & $\begin{array}{c}\mathrm{V} \\
\text { Poorer } \\
\text { outgroup }\end{array}$ \\
\hline \multicolumn{6}{|l|}{ Outgroup economic condition (declining as ref) } \\
\hline Stable & $\begin{array}{l}0.150 * * * \\
(0.0387)\end{array}$ & $\begin{array}{c}0.115^{*} \\
(0.0533)\end{array}$ & $\begin{array}{c}0.127+ \\
(0.0712)\end{array}$ & $\begin{array}{l}-0.0294 \\
(0.0715)\end{array}$ & $\begin{array}{c}0.146+ \\
(0.0776)\end{array}$ \\
\hline Improving & $\begin{array}{c}0.353 * * * \\
(0.0367)\end{array}$ & $\begin{array}{c}0.325 * * * \\
(0.0531)\end{array}$ & $\begin{array}{l}0.201 * * \\
(0.0767)\end{array}$ & $\begin{array}{c}0.173 * \\
(0.0678)\end{array}$ & $\begin{array}{l}0.228 * * \\
(0.0837)\end{array}$ \\
\hline UDC treatment & & $\begin{array}{c}-0.201+ \\
(0.112)\end{array}$ & $\begin{array}{l}-0.127 \\
(0.126)\end{array}$ & $\begin{array}{c}-0.349^{* *} \\
(0.128)\end{array}$ & $\begin{array}{l}-0.0340 \\
(0.130)\end{array}$ \\
\hline \multicolumn{6}{|c|}{ UDC treatment $\times$ Outgroup economic condition (declining as ref) } \\
\hline UDC treatment $\times$ Stable & & $\begin{array}{c}0.0746 \\
(0.0775)\end{array}$ & $\begin{array}{r}-0.0812 \\
(0.103)\end{array}$ & $\begin{array}{l}0.210+ \\
(0.109)\end{array}$ & $\begin{array}{l}-0.119 \\
(0.112)\end{array}$ \\
\hline UDC treatment $\times$ Improving & & $\begin{array}{c}0.0579 \\
(0.0732)\end{array}$ & $\begin{array}{l}0.240 * \\
(0.105)\end{array}$ & $\begin{array}{c}0.0193 \\
(0.0996)\end{array}$ & $\begin{array}{l}0.187+ \\
(0.114)\end{array}$ \\
\hline Richer outgroup & & & $\begin{array}{l}0.438 * * * \\
(0.0734)\end{array}$ & & \\
\hline \multicolumn{6}{|c|}{ Richer outgroup $\times$ Outgroup economic condition (declining as ref) } \\
\hline Richer outgroup $\times$ Stable & & & $\begin{array}{l}-0.101 \\
(0.103)\end{array}$ & & \\
\hline Richer outgroup $\times$ Improving & & & $\begin{array}{l}0.0726 \\
(0.105)\end{array}$ & & \\
\hline UDC treatment $\times$ Richer outgroup & & & $\begin{array}{l}-0.103 \\
(0.112)\end{array}$ & & \\
\hline \multicolumn{6}{|c|}{ UDC treatment $\times$ Richer outgroup $\times$ Outgroup economic condition (declining as ref) } \\
\hline UDC treatment $\times$ Richer outgroup $\times$ Stable & & & $\begin{array}{c}0.247 \\
(0.153)\end{array}$ & & \\
\hline UDC treatment $\times$ Richer outgroup $\times$ Improving & & & $\begin{array}{c}-0.291+ \\
(0.149)\end{array}$ & & \\
\hline Attacks by the outgroup against the ingroup at $t-1$ & $\begin{array}{l}0.349 * * * \\
(0.0167)\end{array}$ & $\begin{array}{l}0.348 * * * \\
(0.0167)\end{array}$ & $\begin{array}{l}0.333 * * * \\
(0.0165)\end{array}$ & $\begin{array}{l}0.257 * * * \\
(0.0210)\end{array}$ & $\begin{array}{l}0.346^{* * *} \\
(0.0255)\end{array}$ \\
\hline \multicolumn{6}{|l|}{ Ingroup rank } \\
\hline Second & & & & ref & $\begin{array}{c}\text { ref } \\
-0.340 * * * \\
(0.0692)\end{array}$ \\
\hline Third & & & & $\begin{array}{c}-0.270 * * * \\
(0.0769)\end{array}$ & $\begin{array}{c}-0.578 * * * \\
(0.0786)\end{array}$ \\
\hline Fourth & & & & $\begin{array}{c}-0.504 * * * \\
(0.0782)\end{array}$ & $\begin{array}{c}-0.470 * * * \\
(0.0975)\end{array}$ \\
\hline Poorest & & & & $\begin{array}{c}-0.695^{* * *} \\
(0.0892)\end{array}$ & \\
\hline Constant & $\begin{array}{c}2.618 * * * \\
(0.0567)\end{array}$ & $\begin{array}{c}2.716^{* * *} \\
(0.0791)\end{array}$ & $\begin{array}{c}2.515^{* * *} \\
(0.0892)\end{array}$ & $\begin{array}{c}3.430 * * * \\
(0.105)\end{array}$ & $\begin{array}{c}2.853 * * * \\
(0.100)\end{array}$ \\
\hline $\ln ($ alpha $)$ & $\begin{array}{c}0.0890 * * * \\
(0.0213)\end{array}$ & $\begin{array}{c}0.0888 * * * \\
(0.0213)\end{array}$ & $\begin{array}{l}0.0600 * * \\
(0.0215)\end{array}$ & $\begin{array}{c}-0.151 * * * \\
(0.0308)\end{array}$ & $\begin{array}{l}0.177 * * * \\
(0.0311)\end{array}$ \\
\hline var(Ingroups) & $\begin{array}{l}0.257 * * * \\
(0.0403)\end{array}$ & $\begin{array}{l}0.252 * * * \\
(0.0395)\end{array}$ & $\begin{array}{l}0.291 * * * \\
(0.0453)\end{array}$ & $\begin{array}{l}0.226^{* * *} \\
(0.0392)\end{array}$ & $\begin{array}{l}0.266^{* * *} \\
(0.0488)\end{array}$ \\
\hline $\begin{array}{l}\text { Observations }^{\mathrm{a}} \\
\text { Number of ingroups }\end{array}$ & $\begin{array}{c}5,520 \\
100\end{array}$ & $\begin{array}{c}5,520 \\
100\end{array}$ & $\begin{array}{c}5,516 \\
100\end{array}$ & $\begin{array}{l}2,758 \\
92\end{array}$ & $\begin{array}{c}2,758 \\
89\end{array}$ \\
\hline
\end{tabular}

Standard errors in parentheses

*** $\mathrm{p}<0.001, * * \mathrm{p}<0.01, * \mathrm{p}<0.05,+\mathrm{p}<0.1$

Observations are ingroup - outgroup dyads for each round of the game (excluding the first round). Rounds in which at least one group died were excluded.

${ }^{a}$ Four ingroup - outgroup dyads had the same level of resources, meaning that there was no richer / poorer group. These four observations were excluded from models III to V.

${ }^{b}$ The number of ingroups vary in models IV and V because some ingroups did not face richer/ poorer outgroups during the game (they were the richest / poorest group all along the game). 
Comments: Model I tests the effect of the outgroup economic condition (declining, stable, improving) on the level of ingroup attacks. Model II tests the interaction between the UDC treatment and the effect of the outgroup economic condition. Model III tests the three-way interaction with the outgroup being richer or poorer. We expected poorer outgroups in improving condition to be attacked more, especially in the UDC treatment.

Results from the three-way interaction are hard to read from the table, so the next figure computes marginal effects. Model III shows a positive effect of the outgroup economic condition on the level of ingroup attacks, but this effect is true both for richer and poorer outgroups. This contradicts our hypothesis that the ingroup generally attacks more outgroups that are getting closer to the ingroup. Indeed, we should observe that the outgroup economic condition only affects attacks against poorer outgroups. Nonetheless, as expected, poorer outgroups are significantly attacked more when they are in improving condition and in the UDC treatment.

As an alternative test, Model IV and $V$ separately test the interaction between the UDC treatment and the effect of the outgroup economic condition for richer and poorer outgroups. In these models, we control for the ingroup rank. Indeed, the ingroup does not face the same number of richer and poorer outgroups depending on its rank, which may affect attack level. Results from models IV and $V$ are similar to those from model III.

Marginal effect of the outgroup economic condition (with 95\% CI)

Computed from the latter negative binomial regressions (model III)

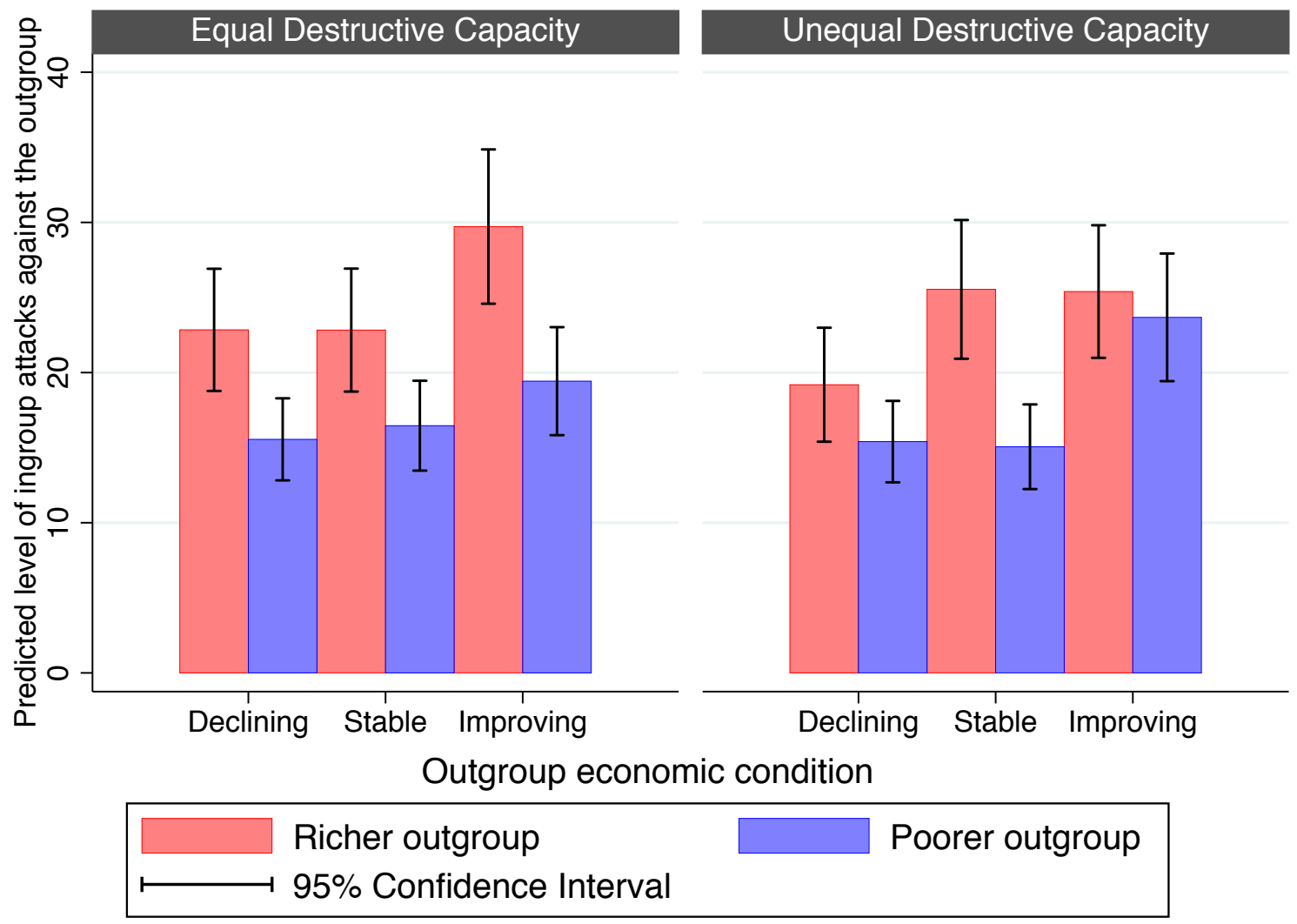




\section{Robustness checks: subject - outgroup dyad}

\section{Fixed effects negative binomial regression models}

Standardized coefficients from negative binomial regression analyses of the individual level of attacks against an outgroup

\begin{tabular}{|c|c|c|c|c|c|}
\hline VARIABLES & \multicolumn{3}{|c|}{ Any outgroup } & $\begin{array}{c}\text { IV } \\
\text { Richer } \\
\text { outgroup }\end{array}$ & $\begin{array}{c}\mathrm{V} \\
\text { Poorer } \\
\text { outgroup }\end{array}$ \\
\hline \multicolumn{6}{|l|}{ Outgroup economic condition (declining as ref) } \\
\hline Stable & $\begin{array}{c}0.0972 * * * \\
(0.0265)\end{array}$ & $\begin{array}{l}0.0688+ \\
(0.0365)\end{array}$ & $\begin{array}{c}0.0240 \\
(0.0526)\end{array}$ & $\begin{array}{c}0.0109 \\
(0.0511)\end{array}$ & $\begin{array}{c}0.0240 \\
(0.0533)\end{array}$ \\
\hline Improving & $\begin{array}{c}0.353 * * * \\
(0.0247)\end{array}$ & $\begin{array}{c}0.299 * * * \\
(0.0353)\end{array}$ & $\begin{array}{c}0.200 * * * \\
(0.0549)\end{array}$ & $\begin{array}{c}0.202 * * * \\
(0.0474)\end{array}$ & $\begin{array}{c}0.212 * * * \\
(0.0556)\end{array}$ \\
\hline UDC treatment & & $-{ }^{\mathrm{a}}$ & $-{ }^{\mathrm{a}}$ & $-{ }^{\mathrm{a}}$ & $-{ }^{\mathrm{a}}$ \\
\hline \multicolumn{6}{|c|}{ UDC treatment $\mathrm{x}$ Outgroup economic condition (declining as ref) } \\
\hline UDC treatment $x$ Stable & & $\begin{array}{c}0.0591 \\
(0.0531)\end{array}$ & $\begin{array}{c}-0.110 \\
(0.0755)\end{array}$ & $\begin{array}{c}0.193 * \\
(0.0787)\end{array}$ & $\begin{array}{c}-0.128+ \\
(0.0764)\end{array}$ \\
\hline UDC treatment $x$ Improving & & $\begin{array}{l}0.0979 * \\
(0.0493)\end{array}$ & $\begin{array}{l}0.222 * * \\
(0.0730)\end{array}$ & $\begin{array}{c}0.0372 \\
(0.0726)\end{array}$ & $\begin{array}{c}0.161 * \\
(0.0738)\end{array}$ \\
\hline Richer outgroup & & & $\begin{array}{c}0.423 * * * \\
(0.0500)\end{array}$ & & \\
\hline \multicolumn{6}{|c|}{ Richer outgroup x Outgroup economic condition (declining as ref) } \\
\hline Richer outgroup x Stable & & & $\begin{array}{c}0.0286 \\
(0.0723)\end{array}$ & & \\
\hline Richer outgroup x Improving & & & $\begin{array}{c}0.0511 \\
(0.0717)\end{array}$ & & \\
\hline UDC treatment $x$ Richer outgroup & & & $\begin{array}{l}-0.153 * \\
(0.0770)\end{array}$ & & \\
\hline \multicolumn{6}{|c|}{ UDC treatment $\mathrm{x}$ Richer outgroup $\mathrm{x}$ Outgroup economic condition (declining as ref) } \\
\hline UDC treatment $x$ Richer outgroup $x$ Stable & & & $\begin{array}{l}0.267^{*} \\
(0.108)\end{array}$ & & \\
\hline UDC treatment $x$ Richer outgroup $x$ Improving & & & $\begin{array}{l}-0.219^{*} \\
(0.102)\end{array}$ & & \\
\hline \multicolumn{6}{|l|}{ Ingroup rank } \\
\hline Richest & & & & & ref \\
\hline Second & & & & ref & $\begin{array}{c}-0.139 * * * \\
(0.0408)\end{array}$ \\
\hline Third & & & & $\begin{array}{c}-0.302 * * * \\
(0.0480)\end{array}$ & $\begin{array}{c}-0.361 * * * \\
(0.0499)\end{array}$ \\
\hline Fourth & & & & $\begin{array}{c}-0.457 * * * \\
(0.0492)\end{array}$ & $\begin{array}{c}-0.344 * * * \\
(0.0660)\end{array}$ \\
\hline Poorest & & & & $\begin{array}{c}-0.526 * * * \\
(0.0524)\end{array}$ & \\
\hline Attacks by the outgroup against the ingroup at $\mathrm{t}-1$ & $\begin{array}{l}0.229 * * * \\
(0.00867)\end{array}$ & $\begin{array}{l}0.230 * * * \\
(0.00869)\end{array}$ & $\begin{array}{l}0.220 * * * \\
(0.00869)\end{array}$ & $\begin{array}{c}0.147 * * * \\
(0.0122)\end{array}$ & $\begin{array}{c}0.246^{* * * *} \\
(0.0144)\end{array}$ \\
\hline Constant & $\begin{array}{c}-1.307 * * * \\
(0.0206)\end{array}$ & $\begin{array}{c}-1.321 * * * \\
(0.0282)\end{array}$ & $\begin{array}{c}-1.491 * * * \\
(0.0368)\end{array}$ & $\begin{array}{c}-0.585 * * * \\
(0.0582)\end{array}$ & $\begin{array}{c}-1.301 * * * \\
(0.0462)\end{array}$ \\
\hline Observations & 16,372 & 16,372 & $16,360^{\mathrm{b}}$ & 8,040 & 8,169 \\
\hline Number of subjects ${ }^{\mathrm{c}, \mathrm{d}}$ & 299 & 299 & 299 & 271 & 260 \\
\hline
\end{tabular}

Standard errors in parentheses

$* * * \mathrm{p}<0.001, * * \mathrm{p}<0.01, * \mathrm{p}<0.05,+\mathrm{p}<0.1$

Observations are subject - outgroup dyads for each round of the game (excluding the first round). Rounds in which at least one group died were excluded.

${ }^{\mathrm{a}}$ The UDC treatment variable was included in the model, but because it is perfectly collinear with subject fixed effects, the coefficients was omitted from the table. 
${ }^{b}$ Four ingroup - outgroup dyads had the same level of resources, meaning that there was no richer / poorer group. As each ingroup gathers three subjects, twelve subject - outgroup dyads were excluded from models III to V.

${ }^{c}$ One subject was automatically omitted from the analyses because his level of attacks was 0 against all outgroups in all rounds, and hence was perfectly predicted by the subject fixed effect.

${ }^{\mathrm{d}}$ The number of subjects vary in models IV and V because some subjects did not face richer / poorer outgroups during the game (they were part of the richest / poorest group all along the game).

\section{Comments:}

We test the same models than the previous table based on subject - outgroup dyads, including subject fixed effects. As shown by the following marginal effects, the results are essentially unchanged regarding our hypothesis. Outgroups are generally attacks more when they are in improving economic condition, and poorer outgroups are significantly attacked more when they are in improving condition and in the UDC treatment.

Marginal effect of the outgroup economic condition (with 95\% CI) Computed from the latter fixed effects negative binomial regressions (model III)

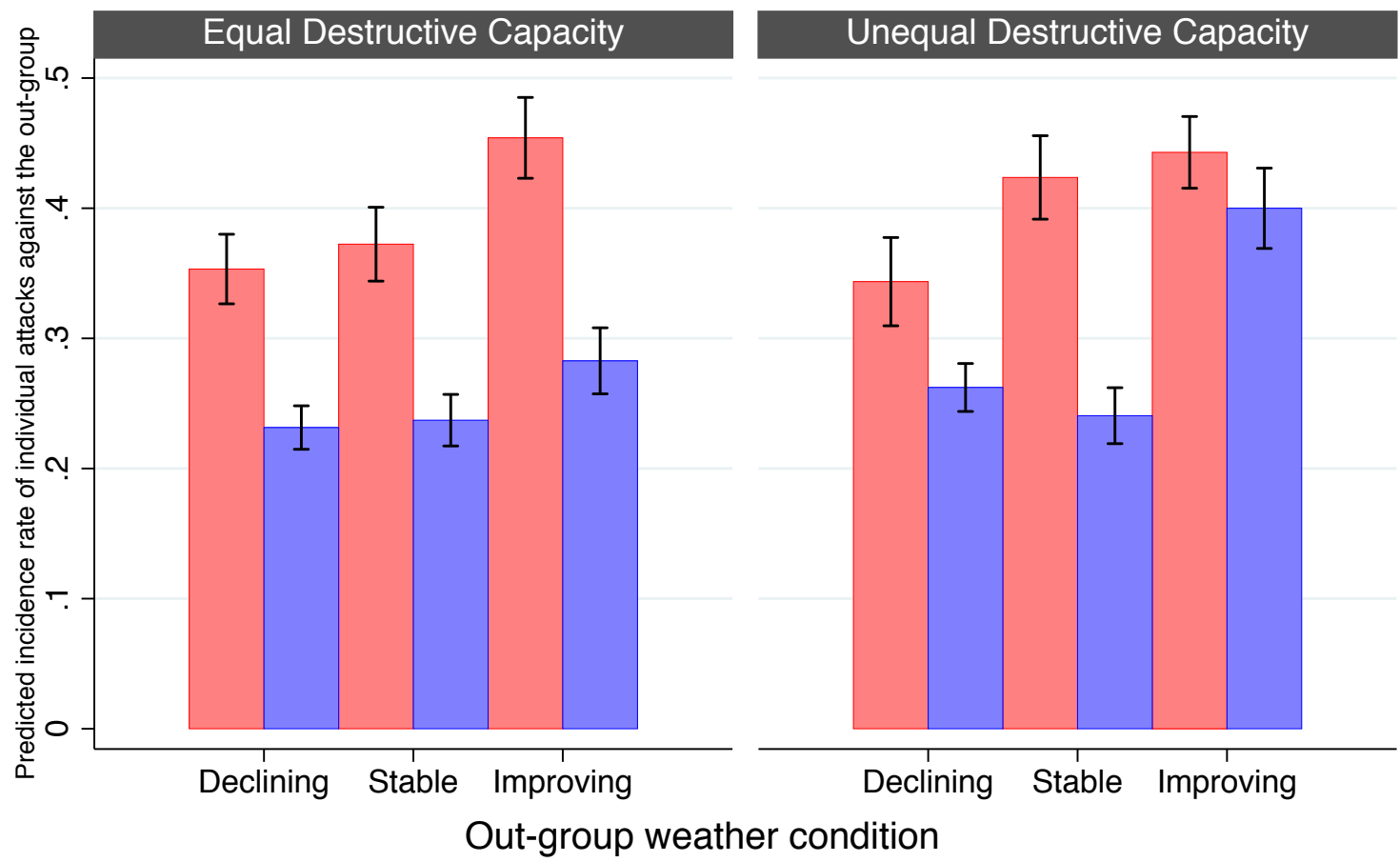




\section{Zero-inflated negative binomial regression models}

Standardized coefficients from zero-inflate negative binomial regression analyses of the individual level of attacks against an outgroup

\begin{tabular}{|c|c|c|c|c|c|c|c|c|c|c|}
\hline \multirow[b]{2}{*}{ VARIABLES } & & I & Any o & $\begin{array}{l}\text { itgroup } \\
\text { I }\end{array}$ & & I & \multicolumn{2}{|c|}{$\begin{array}{c}\text { Richer outgroup } \\
\text { IV }\end{array}$} & \multicolumn{2}{|c|}{$\begin{array}{c}\text { Poorer outgroup } \\
\text { V }\end{array}$} \\
\hline & $\begin{array}{l}\text { Level of } \\
\text { attacks }\end{array}$ & $\begin{array}{l}\text { Inflate: } \\
\text { absence of } \\
\text { attack }\end{array}$ & $\begin{array}{l}\text { Level of } \\
\text { attacks }\end{array}$ & $\begin{array}{l}\text { Inflate: } \\
\text { absence of } \\
\text { attack }\end{array}$ & $\begin{array}{l}\text { Level of } \\
\text { attacks }\end{array}$ & $\begin{array}{l}\text { Inflate: } \\
\text { absence of } \\
\text { attack }\end{array}$ & $\begin{array}{l}\text { Level of } \\
\text { attacks }\end{array}$ & $\begin{array}{l}\text { Inflate: } \\
\text { absence of } \\
\text { attack }\end{array}$ & $\begin{array}{l}\text { Level of } \\
\text { attacks }\end{array}$ & $\begin{array}{l}\text { Inflate: } \\
\text { absence of } \\
\text { attack }\end{array}$ \\
\hline Outgroup economic condition (declining as ref) & & & & & & & & & & \\
\hline Stable & $\begin{array}{c}0.0523 \\
(0.0405)\end{array}$ & $\begin{array}{l}-0.119 \\
(0.0727)\end{array}$ & $\begin{array}{c}0.103+ \\
(0.0544)\end{array}$ & $\begin{array}{r}-0.0690 \\
(0.103)\end{array}$ & $\begin{array}{c}0.153^{*} \\
(0.0699)\end{array}$ & $\begin{array}{r}-0.0132 \\
(0.112)\end{array}$ & $\begin{array}{c}0.0427 \\
(0.0737)\end{array}$ & $\begin{array}{l}0.0219 \\
(0.147)\end{array}$ & $\begin{array}{c}0.142 * \\
(0.0684)\end{array}$ & $\begin{array}{l}-0.000645 \\
(0.112)\end{array}$ \\
\hline Improving & $\begin{array}{l}0.0971 * * \\
(0.0345)\end{array}$ & $\begin{array}{c}-0.452 * * * \\
(0.0663)\end{array}$ & $\begin{array}{l}0.155 * * \\
(0.0479)\end{array}$ & $\begin{array}{c}-0.368 * * * \\
(0.0829)\end{array}$ & $\begin{array}{c}0.0931 \\
(0.0819)\end{array}$ & $\begin{array}{l}-0.229 * \\
(0.108)\end{array}$ & $\begin{array}{c}0.104+ \\
(0.0572)\end{array}$ & $\begin{array}{l}-0.257^{*} \\
(0.106)\end{array}$ & $\begin{array}{c}0.0921 \\
(0.0796)\end{array}$ & $\begin{array}{l}-0.215^{*} \\
(0.108)\end{array}$ \\
\hline UDC treatment & & & $\begin{array}{l}-0.0970 \\
(0.0723)\end{array}$ & $\begin{array}{l}0.0235 \\
(0.149)\end{array}$ & $\begin{array}{l}-0.0433 \\
(0.0850)\end{array}$ & $\begin{array}{l}-0.172 \\
(0.175)\end{array}$ & $\begin{array}{l}-0.122 \\
(0.111)\end{array}$ & $\begin{array}{c}0.273 \\
(0.196)\end{array}$ & $\begin{array}{l}-0.0512 \\
(0.0827)\end{array}$ & $\begin{array}{l}-0.179 \\
(0.176)\end{array}$ \\
\hline $\begin{array}{l}\text { UDC treatment } x \text { Outgroup economic condition (declining as } \\
\text { ref) }\end{array}$ & & & & & & & & & & \\
\hline UDC treatment x Stable & & & $\begin{array}{l}-0.105 \\
(0.0815)\end{array}$ & $\begin{array}{l}-0.106 \\
(0.144)\end{array}$ & $\begin{array}{r}-0.0922 \\
(0.104)\end{array}$ & $\begin{array}{c}0.158 \\
(0.166)\end{array}$ & $\begin{array}{l}-0.191 \\
(0.119)\end{array}$ & $\begin{array}{l}-0.433^{*} \\
(0.212)\end{array}$ & $\begin{array}{l}-0.0635 \\
(0.102)\end{array}$ & $\begin{array}{c}0.161 \\
(0.166)\end{array}$ \\
\hline UDC treatment $x$ Improving & & & $\begin{array}{l}-0.0865 \\
(0.0671)\end{array}$ & $\begin{array}{l}-0.154 \\
(0.127)\end{array}$ & $\begin{array}{c}0.143 \\
(0.102)\end{array}$ & $\begin{array}{c}-0.300+ \\
(0.156)\end{array}$ & $\begin{array}{l}-0.244 * \\
(0.103)\end{array}$ & $\begin{array}{l}-0.183 \\
(0.171)\end{array}$ & $\begin{array}{c}0.134 \\
(0.0983)\end{array}$ & $\begin{array}{c}-0.264+ \\
(0.155)\end{array}$ \\
\hline Richer outgroup & & & & & $\begin{array}{c}0.108 \\
(0.0746)\end{array}$ & $\begin{array}{c}-0.547 * * * \\
(0.147)\end{array}$ & & & & \\
\hline $\begin{array}{l}\text { Richer outgroup x Outgroup economic condition (declining as } \\
\text { ref) }\end{array}$ & & & & & & & & & & \\
\hline $\begin{array}{l}\text { Richer outgroup x Stable } \\
\text { Richer outgroup x Improving }\end{array}$ & & & & & $\begin{array}{l}-0.103 \\
(0.106) \\
0.0628 \\
(0.0928)\end{array}$ & $\begin{array}{c}-0.00916 \\
(0.155) \\
-0.0712 \\
(0.136)\end{array}$ & & & & \\
\hline UDC treatment $x$ Richer outgroup & & & & & $\begin{array}{l}-0.112 \\
(0.120)\end{array}$ & $\begin{array}{l}0.455^{*} \\
(0.222)\end{array}$ & & & & \\
\hline $\begin{array}{l}\text { UDC treatment } x \text { Richer outgroup } \times \text { Outgroup economic } \\
\text { condition (declining as ref) } \\
\text { UDC treatment } x \text { Richer outgroup } \times \text { Stable }\end{array}$ & & & & & -0.00131 & $-0.574 *$ & & & & \\
\hline
\end{tabular}


UDC treatment $x$ Richer outgroup $x$ Improving

Ingroup rank

Richest

Second

Third

Fourth

Poorest

Attacks by the outgroup against the ingroup at $\mathrm{t}-1$

Constant

Observations $\mathrm{s}^{\mathrm{a}, \mathrm{b}}$

$* * * \mathrm{p}<0.001, * * \mathrm{p}<0.01, * \mathrm{p}<0.05,+\mathrm{p}<0.1$

Observations are all subject - outgroup dyads for each round of the game (excluding the first round). Rounds in which at least one group died were excluded.

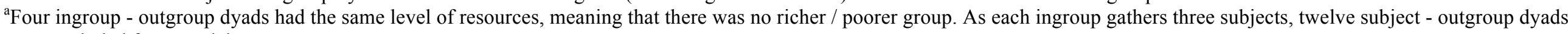
were excluded from models III to $\mathrm{V}$.

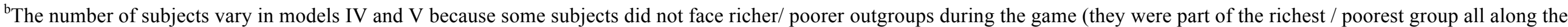
game).

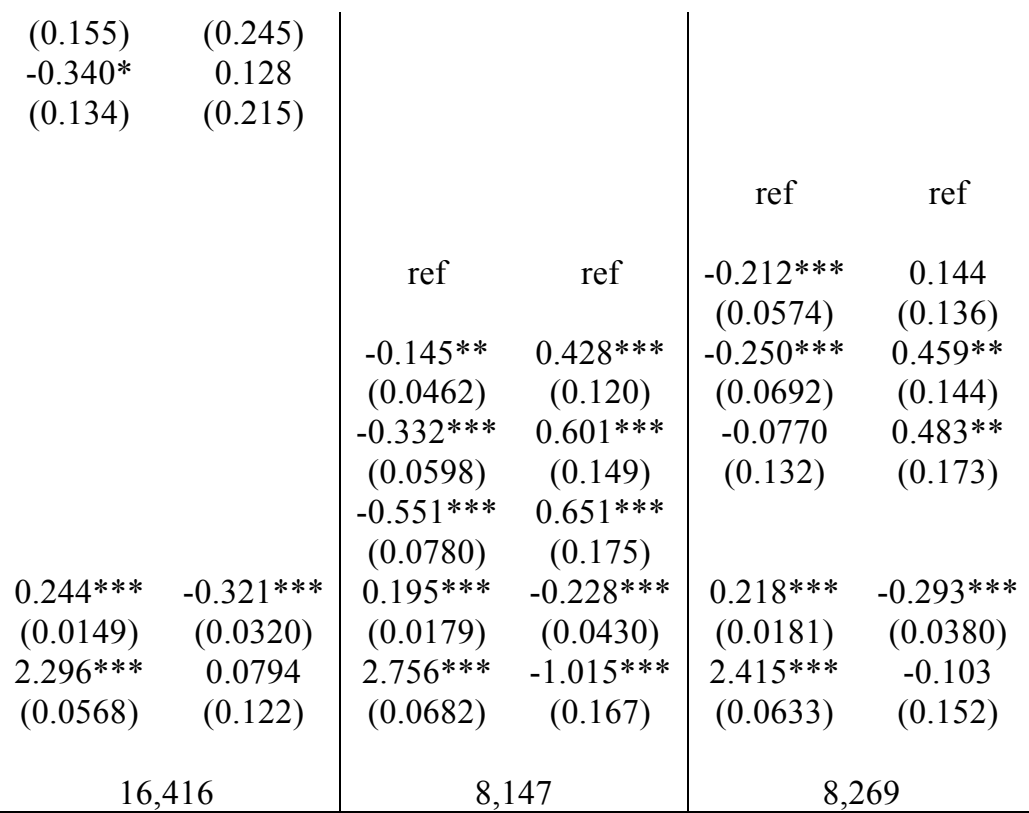

16,416
$0.245 * * *$

$(0.0154)$

$2.347 * * *$

$-0.307 * * *$

$2.303 * *$

$(0.0485)$
16,428 
Comments:

We test the same models than the previous table but based on a zero-inflated negative binomial regression - which separately predicts the absence of individual attack (by a logistic model) and, if an attack occurred, the level of attacks (by a count model). For each model, the first row shows the effects of the predictors on the level of attack (non-zero count negative binomial), and the second row shows the effects of the predictors on the probability of no attack (certain zeros logit).

As shown by the following marginal effects, the results are essentially unchanged.

Marginal effect of the outgroup economic condition (with 95\% CI)

Computed from the zero-inflated negative binomial regressions (model III)

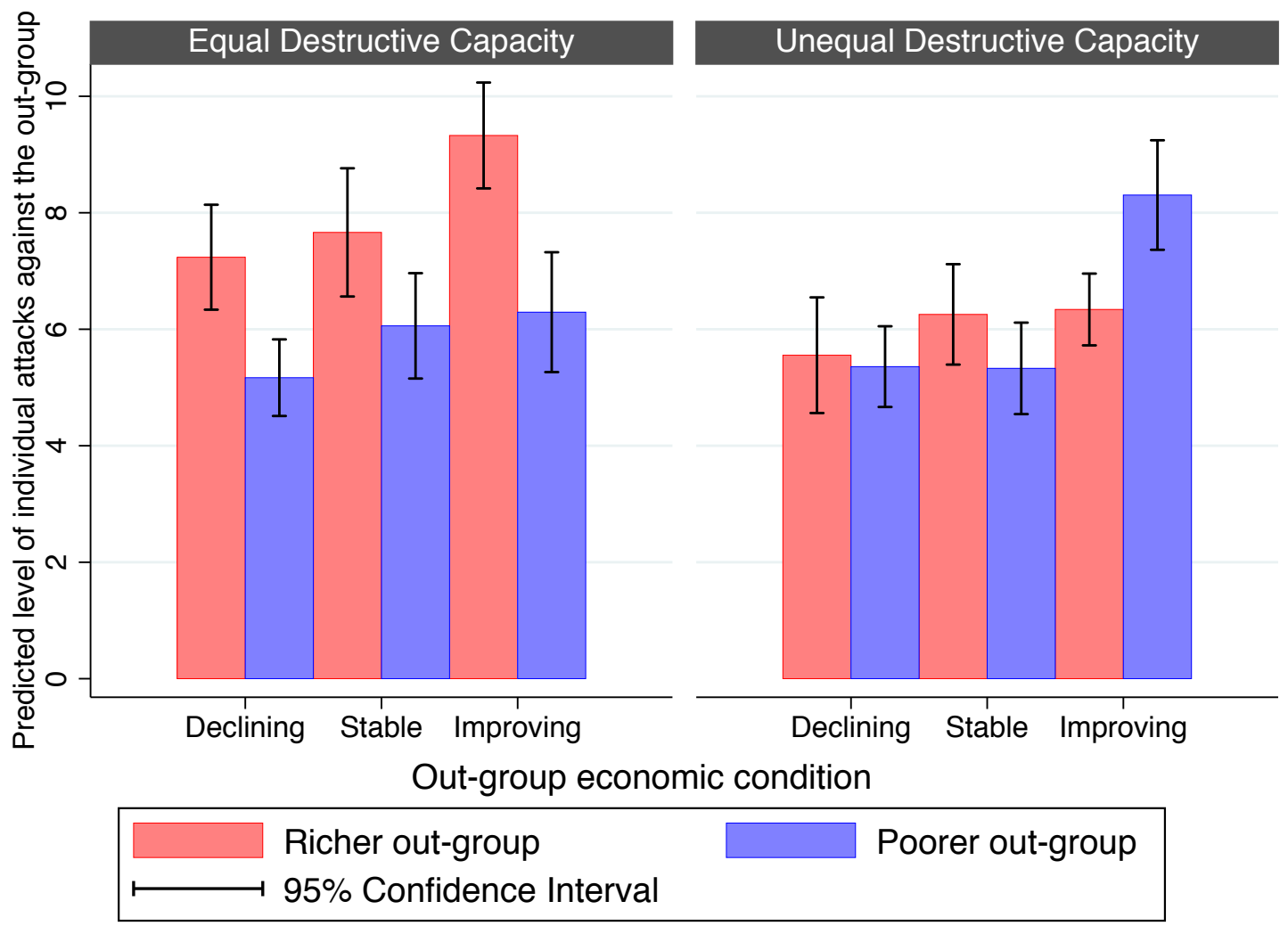




\section{Study 2: terrorist attacks}

\section{Rationale for the control variables}

In Study 2, we control for a range of factors that have proven to affect terrorist attacks in general, or left-wing versus right-wing terrorism in particular. A country's population mechanically increases the number of terrorist attacks (Kis-Katos et al., 2011, Freytag et al., 2011, Choi \& Piazza, 2016, Krieger \& Meierrieks, 2019, Piazza, 2017). Moreover, since terrorists are mostly young individuals, we control for the share of youth population (Urdal, 2006). We also control for political-institutional variables. Various studies show that the ethno-political discriminations are a main driver of terrorism (Choi \& Piazza, 2016, Krieger \& Meierrieks, 2019). Following these studies, we control for the share of discriminated population. The level of democracy is generally positively associated with terrorist attacks (Kis-Katos et al., 2011, Freytag et al., 2011, Piazza, 2017). Among other variables, regime durability has been found to reduce terrorism (Freytag et al., 2011, Piazza, 2017), and there is evidence that government size has a positive effect on terrorism (Freytag et al., 2011). Besides, studies generally find civil war to be positively associated with terrorist attacks (Kis-Katos et al., 2011, Freytag et al., 2011, Krieger \& Meierrieks, 2019, Piazza, 2017). Finally, we control for economic variables. There is conflicting evidence about the effect of economic development - captured by the log GDP capita: some studies find a negative effect (Abadie, 2006, Caruso \& Schneider, 2011), while others rather find a positive effect (Kis-Katos et al., 2011, Freytag et al., 2011). Besides, evidence indicates that long-term economic growth has a differential effect on left-wing and right-wing terrorism: increasing left-wing terrorism and decreasing right-wing terrorism (Varaine, 2018, 2019).

Abadie, A. (2006). Poverty, political freedom, and the roots of terrorism. American Economic Review, 96(2), 50-56.

Caruso, R., \& Schneider, F. (2011). The socio-economic determinants of terrorism and political violence in Western Europe (1994-2007). European Journal of Political Economy, 27, S37-S49.

Choi, S.-W., \& Piazza, J. A. (2016). Ethnic groups, political exclusion and domestic terrorism. Defence and Peace Economics, 27(1), 37-63.

Freytag, A., Krüger, J. J., Meierrieks, D., \& Schneider, F. (2011). The origins of terrorism : Cross-country estimates of socio-economic determinants of terrorism. European Journal of Political Economy, 27, S5-S16.

Kis-Katos, K., Liebert, H., \& Schulze, G. G. (2011). On the origin of domestic and international terrorism. European Journal of Political Economy, 27, S17-S36.

Krieger, T., \& Meierrieks, D. (2019). Income inequality, redistribution and domestic terrorism. World Development, 116, $125-136$.

Piazza, J. A. (2017). Repression and terrorism : A cross-national empirical analysis of types of repression and domestic terrorism. Terrorism and Political Violence, 29(1), 102-118.

Urdal, H. (2006). A clash of generations? Youth bulges and political violence. International studies quarterly, 50(3), 607-629.

Varaine, S. (2018). Bad times are not good times for revolutions: Collective deprivation and the mobilization level of $F$ rench radical movements (1882-1980). Journal of Community \& Applied Social Psychology, 28(4), 258-271. 
Varaine, S. (2019). Revisiting the Economics and Terrorism Nexus: Collective Deprivation, Ideology and Domestic Radicalization in the US (19482016). Journal of Quantitative Criminology, 1-33.

\section{Data sources}

\begin{tabular}{|c|c|}
\hline Variable & Source \\
\hline Number of left-wing terrorist attacks & \multirow{2}{*}{$\begin{array}{l}\text { Computed from the Global Terrorism Database based on coding of Kis-Katos et al. (2014). National } \\
\text { Consortium for the Study of Terrorism and Responses to Terrorism (START). (2017). Global } \\
\text { Terrorism Database. http://www.start.umd.edu/gtd/ See Kis-Katos, K., Liebert, H., \& Schulze, G. G. } \\
\text { (2014). On the heterogeneity of terror. European Economic Review, 68, 116-136. }\end{array}$} \\
\hline Number of right-wing terrorist attacks & \\
\hline Share of income owned by $1 \%$ richest (t-1) & World Inequality Database. (2017). Pre-tax national income-Top 1\% share. http://wid.world/data/ \\
\hline $\log$ GDP per capita (t-1) & $\begin{array}{l}\text { World Bank. (2018). GDP per capita (current US\$). } \\
\text { http://data.worldbank.org/indicator/NY.GDP.PCAP.CD }\end{array}$ \\
\hline log Population (t-1) & World Bank. (2018). Population, total. http://data.worldbank.org/indicator/sp.pop.totl \\
\hline Youth population share (t-1) & $\begin{array}{l}\text { Computed from the World Population Prospects database. United Nations. (2017). Population by Age } \\
\text { Groups_Both Sexes. http://esa.un.org/unpd/wpp/DVD/Files/1_Indicators } \\
\text { (Standard)/EXCEL_FILES/1_Population/WPP2015_POP_F07_1_POPULATION_BY_AGE_BOTH } \\
\text { SEXES.XLS }\end{array}$ \\
\hline Ethno-political exclusion (t-1) & $\begin{array}{l}\text { Computed from the Ethnic Power Relations dataset. Vogt, M., Bormann, N.-C., Rüegger, S., } \\
\text { Cederman, L.-E., Hunziker, P., \& Girardin, L. (2015). Integrating Data on Ethnicity, Geography, and } \\
\text { Conflict: The Ethnic Power Relations Data Set Family. Journal of Conflict Resolution. } \\
\text { https://doi.org/10.1177/0022002715591215 }\end{array}$ \\
\hline Government size (t-1) & $\begin{array}{l}\text { World Bank. (2018). Expense (\% of GDP). } \\
\text { http://data.worldbank.org/indicator/GC.XPN.TOTL.GD.ZS }\end{array}$ \\
\hline Democracy (t-1) & \multirow{2}{*}{$\begin{array}{l}\text { Center for Systemic Peace. (2018). Polity IV Project—Political Regime Characteristics and } \\
\text { Transitions, 1800-2016. http://www.systemicpeace.org/inscrdata.html }\end{array}$} \\
\hline Regime durability (t-1) & \\
\hline Civil war (t-1) & $\begin{array}{l}\text { Center for Systemic Peace. (2018). Major Episodes of Political Violence (MEPV) and Conflict } \\
\text { Regions, 1946-2016. http://www.systemicpeace.org/inscrdata.html }\end{array}$ \\
\hline GDP growth over 5 years $(t-1)$ & $\begin{array}{l}\text { Computed from the Maddison Project Database, version 2018. Bolt, J., Inklaar, R., de Jong, H., \& Van } \\
\text { Zanden, J. L. (2018). Rebasing 'Maddison' : New income comparisons and the shape of long-run } \\
\text { economic development. GGDC Research Memorandum, } 174 \text {. }\end{array}$ \\
\hline
\end{tabular}




\section{Descriptive statistics}

\begin{tabular}{|c|c|c|c|c|c|c|}
\hline Variable & Unit / description & Obs & Mean & $\begin{array}{l}\text { Std. } \\
\text { Dev. }\end{array}$ & Min & $\operatorname{Max}$ \\
\hline Number of left-wing terrorist attacks & Count of terrorist events by left-wing groups & 652 & 11.6 & 42 & 0 & 517 \\
\hline Number of right-wing terrorist attacks & Count of terrorist events by right-wing groups & 652 & 1.34 & 5.62 & 0 & 103 \\
\hline Share of income owned by $1 \%$ richest $(t-1)$ & Share of the pre-tax national income owned by the top $1 \%$ & 652 & .109 & .0548 & .0349 & .294 \\
\hline $\log$ GDP per capita $(t-1)$ & $\log$ of GDP per capita in current US $\$$ & 652 & 9.2 & 1.36 & 4.57 & 11.5 \\
\hline $\log$ Population (t-1) & $\log$ of total population & 652 & 17.5 & 1.43 & 15 & 21 \\
\hline Youth population share $(t-1)$ & $\begin{array}{l}\text { Share of total population aged 20-29 (quinquennial } \\
\text { estimate) }\end{array}$ & 652 & .156 & .0183 & .115 & .198 \\
\hline Ethno-political exclusion (t-1) & $\begin{array}{l}\text { Share of total population member of a discriminated ethnic } \\
\text { group }\end{array}$ & 652 & .0305 & .142 & 0 & .85 \\
\hline Government size (t-1) & Share of GDP & 652 & .289 & .0965 & .0858 & .509 \\
\hline Democracy $(t-1)$ & Score from - 10 (autocracy) to 10 (democracy) & 652 & 8.59 & 3.41 & -7 & 10 \\
\hline Regime durability (t-1) & Number of years since the most recent regime change & 652 & 54.3 & 47 & 0 & 205 \\
\hline Civil war (t-1) & $\begin{array}{l}\text { Magnitude score of episode(s) of civil warfare involving } \\
\text { that state from } 0 \text { to } 10\end{array}$ & 652 & .123 & .774 & 0 & 5 \\
\hline GDP growth over 5 years $(t-1)$ & $\begin{array}{l}\text { Five-year growth of the real GDP per capita in } 2011 \text { US \$, } \\
2011 \text { benchmark }\end{array}$ & 652 & .12 & .097 & -.382 & .457 \\
\hline
\end{tabular}

